\title{
THE BENCHMARK FARM PROGRAM - A METHOD FOR ESTIMATING IRRIGATION WATER USE IN SOUTHWEST FLORIDA
}

U.S. GEOLOGICAL SURVEY

WATER-RESOURCES INVESTIGATIONS 82-17
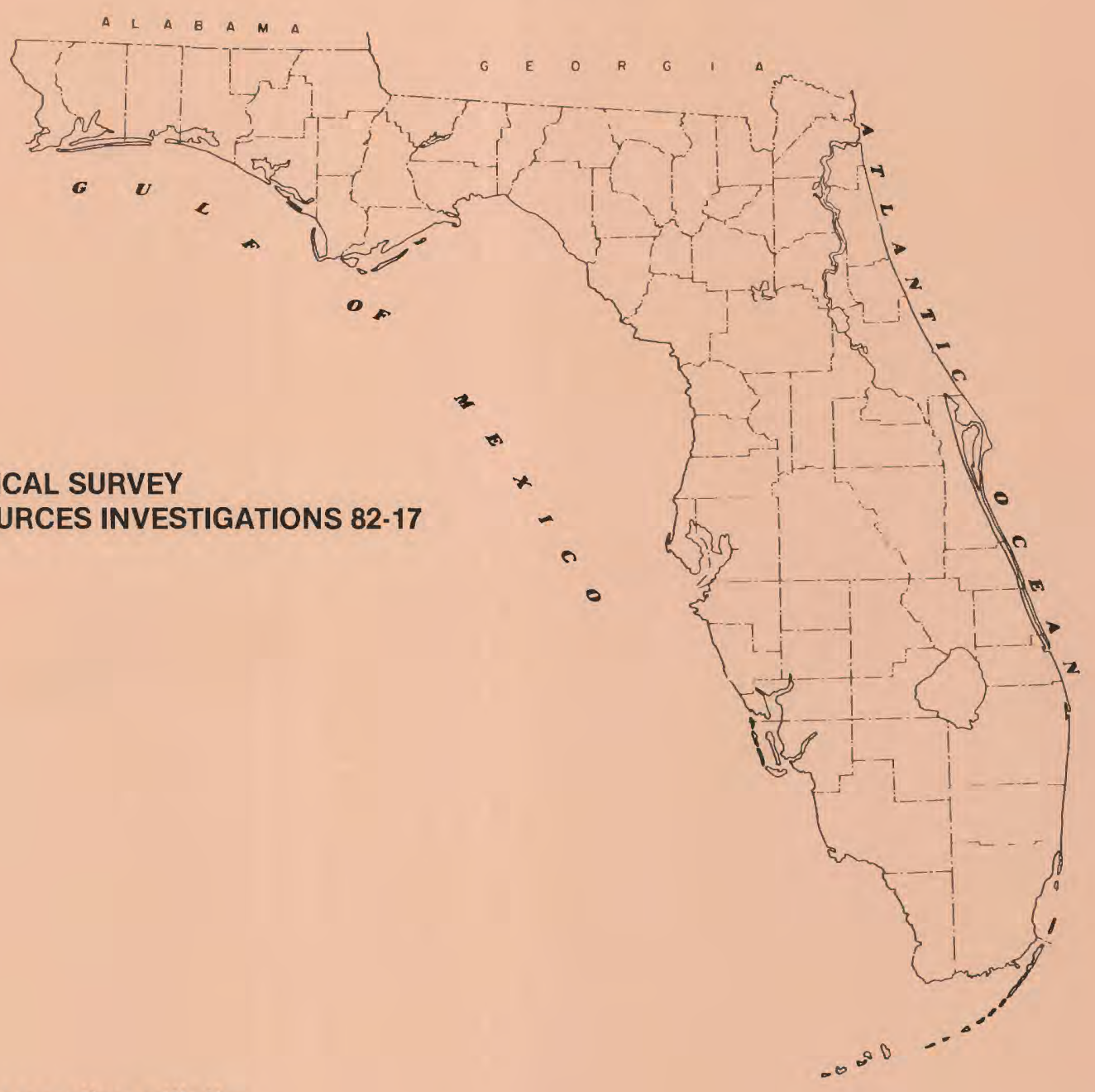

Prepared in cooperation with the

SOUTHWEST FLORIDA WATER MANAGEMENT DISTRICT

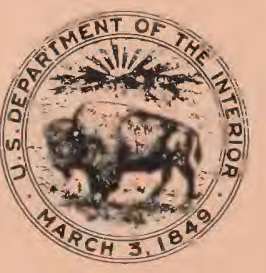




\begin{tabular}{|l|l|}
\hline REPORT DOCUMENTATION & 1. REPORT NO. \\
PAGE
\end{tabular}

\section{Title and Subtitle}

THE BENCHMARK FARM PROGRAM--A METHOD FOR ESTIMATING IRRIGATION WATER USE IN SOUTHWEST FLORIDA

\section{Author(s)}

A. D. Duerr and J. T. Trommer

9. Performing Organization Name and Address

U.S. Geological Survey, Water Resources Division

325 John Knox Road, Suite F-240

Tallahassee, Florida 32303

\section{Sponsoring Organization Name and Address}

U.S. Geological Survey, Water Resources Division

325 John Knox Road, Suite F-240

Tallahassee, Florida 32303

\section{2.}

IRRIGATION

\section{Supplementary Notes}

Prepared in cooperation with the Southwest Florida Water Management District

\section{Abstract (Limit: 200 words)}

The benchmark farm program is a method for selected sampling of irrigation water-use data to provide a base for estimating water use in an area. Irrigation water-use data are summarized in this report for 74 farms in southwest Florida. Most data are for 1978-80, but 18 farms have data from the early 1970's. Data include site number and location, season and year, crop type, irrigated acres, irrigation system, monitoring method, and inches of water applied per acre.

Crop types include citrus, cucumbers, pasture, peanuts, sod, strawberries, tomatoes, and watermelons. Water used for irrigation by golf courses, nurseries, and tropical fish farms are also included. Water-application rates per growing season ranged from no irrigation on several citrus and pasture sites to 239.7 inches per acre for a nursery site. The report also includes rainfall data for 12 stations throughout the study area.

17. Document Analysis a. Descriptors

*Irrigation water, *Water use, Crops, Irrigation systems

b. Identifiers/Open-Ended Terms

Southwest Florida Water Management District, Florida

C. COSATI Field/Group

18. Availability Statement

No restriction on distribution

19. Security Class (This Report)

UNCLASSIFIED

20. Security Class (This Page)

UNCLASS IF IED 
THE BENCHMARK FARM PROGRAM--A METHOD FOR ESTIMATING

IRRIGATION WATER USE IN SOUTHWEST FLORIDA

By A. D. Duerr and J. T. Trommer

U.S. GEOLOGICAL SURVEY

Water-Resources Investigations 82-17

Prepared in cooperation with the

SOUTHWEST FLORIDA WATER MANAGEMENT DISTRICT

Tallahassee, Florida

1982 
UNITED STATES DEPARTMENT OF THE INTERIOR

JAMES G. WATT, Secretary

GEOLOGICAL SURVEY

Dallas L. Peck, Director

For additional information write to:

U.S. Geological Survey

325 John Knox Road, Suite F-240

Tallahassee, Florida 32303 


\section{CONTENTS}

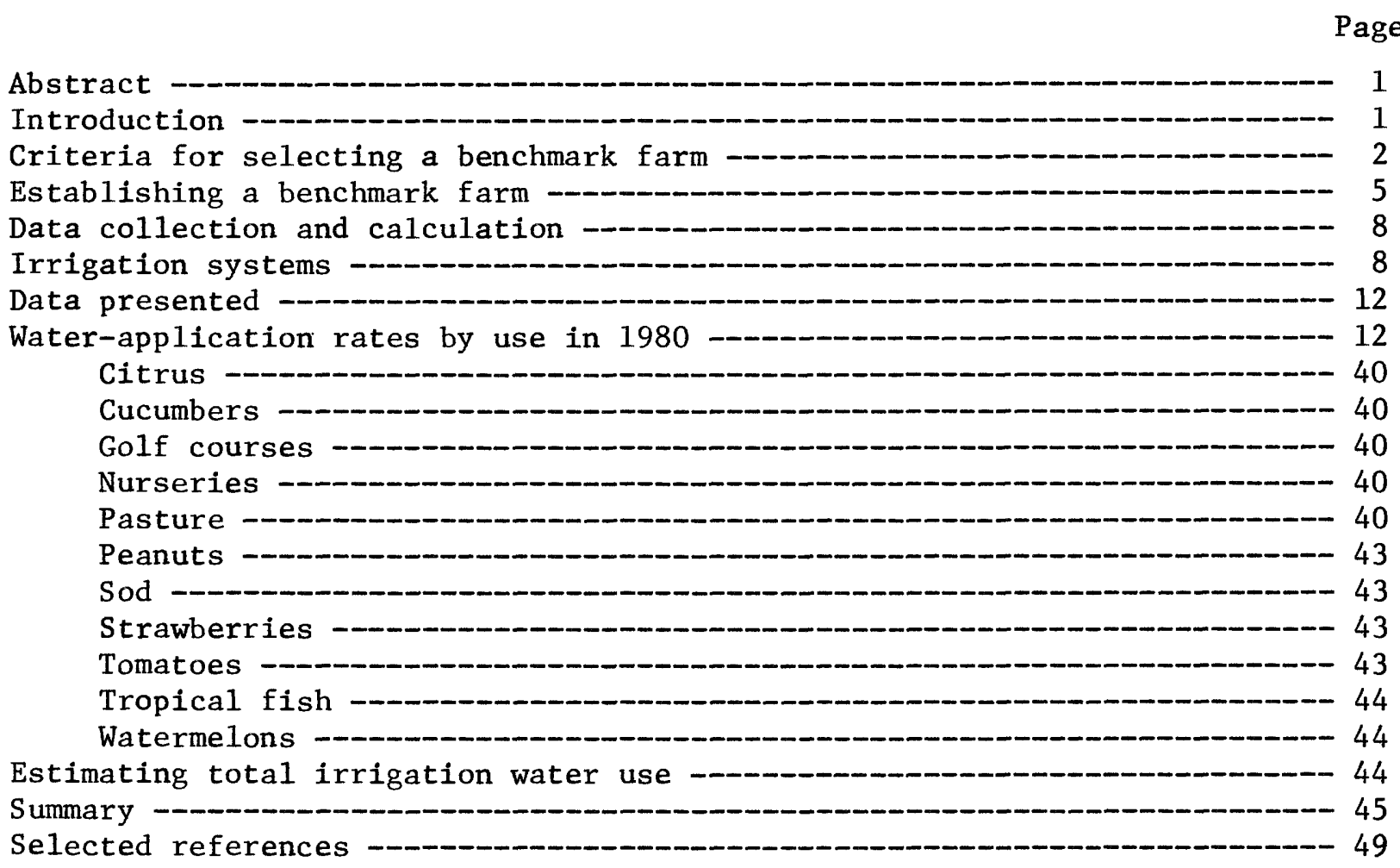

\section{ILLUSTRATIONS}

Page

Figure 1. Map showing location of study area

2. Map showing location of benchmark farms and rainfa11 stations -

3. Photograph showing sonic flow meter used for measuring pump discharge - 6

4. Photograph showing saddle flow meter, electric meter, and vibration-time totalizer used for recording pumpage - - - 7

5. Photograph showing seepage, semiclosed, and closed-pipe irrigation systems - 9

6. Photograph showing drip, jet, and overhead irrigation systems - 10

7. Photograph showing sprinkler and volume-gun irrigation systems -

8. Graph showing rainfall for stations in central and southern parts of the study area, 1978-80 34

9. Graph showing rainfall for stations in west-central and northern parts of the study area, 1978-80

10. Graph showing rainfall at Lakeland, 1970-8C - 36 
Figure 11. Graph showing rainfall at Wimauma and Tampa and water applied at sites 26 and 64, 1980

12. Graph showing rainfa11 at Bartow and Plant City and water applied at sites 8 and 36, 1980-81 38

13. Graph showing rainfall at Lakeland and water applied at site 1, 1970-80 - 39

14. Graph showing adjusted water-application rates by crop, $1980-46$

\section{TABLES}

Table 1. Records of benchmark farms 13

2. Water applied monthly by crop and irrigation system at benchmark farms - 21

3. Water use by crop, season, and type of irrigation system, 1980 - 41

4. Crop calendar and adjusted monthly water-application rates by crop, 1980

\section{ABBREVIATIONS AND CONVERSION FACTORS}

Factors for converting inch-pound units to International System (SI) units and abbreviation of units

\section{Multiply}

inch (in)

acre

inch per acre (in/acre)

acre-foot (acre-ft)

square mile $\left(\mathrm{mi}^{2}\right)$

gallon (gal)

gallon per minute (gal/min)

gallon per hour (gal/h)
By

25.4

0.004047

62.76

1,233

2.590

3.785

0.6309

3.7854
To obtain

millimeter (mm)

square kilometer $\left(\mathrm{km}^{2}\right)$

millimeter per hectare

$$
\text { (mm/ha) }
$$

cubic meter $\left(\mathrm{m}^{3}\right)$

square kilometer $\left(\mathrm{km}^{2}\right)$

liter (L)

liter per second (L/S)

liter per second (L/S) 


\section{THE BENCHMARK FARM PROGRAM--A METHOD FOR ESTIMATING}

IRRIGATION WATER USE IN SOUTHWEST FLORIDA

By A. D. Duerr and J. T. Trommer

ABSTRACT

The benchmark farm program is a method of selected sampling of irrigation water-use data to provide a base for estimating water use in an area. Irrigation water-use data are summarized in this report for 74 farms in southwest Florida. Most data are for 1978-80, but 18 farms have data from the early $1970^{\prime}$ s. Data include site number and location, season and year, crop type, irrigated acres, irrigation system, monitoring method, and inches of water applied per acre.

Crop types include citrus, cucumbers, pasture, peanuts, sod, strawberries, tomatoes, and watermelons. Water used for irrigation by golf courses, nurseries, and tropical fish farms are also included. Water-application rates per growing season ranged from no irrigation on several citrus and pasture sites to 239.7 inches per acre for a nursery site. The report also includes rainfall data for 12 stations throughout the study area.

\section{INTRODUCTION}

Southwest Florida has undergone rapid population growth during the last decade. This growth has increased competition among users of water for all purposes. The 1970 and 1975 water-use inventories (Pride, 1973; Leach, 1978) indicated a need for annual updates of water-use data. The need is particularly important in areas of rapidly increasing population where industries have been established or expanded, where agricultural irrigation has expanded, and where thermoelectric power generation has increased. Water-use data are used in quantitative water-resources investigations, such as predicting waterlevel declines, saltwater encroachment, and in determining future demands for water.

In 1976, the Southwest Florida Water Management District entered into a cooperative agreement with the U.S. Geological Survey to collect water-use data annually within the water management district. Water-use data for 1977 are included in a statewide report by Leach and Healy (1980) and data for 1978 and 1979 are currently (1981) being compiled for release. Reports by Duerr and Trommer (1981a; 1981b) present 1979 and 1980 water-use data for southwest Florida.

Irrigation water-use data are included in each of the above reports. The irrigation water-use category includes water that is derived from ground-water and surface-water sources. It does not include water supplied by a publicsupply system. Irrigation water-use data are not easily obtained and are the 
least accurate of all water-use categories. One reason for this is that water withdrawn for irrigation is not required to be metered or reported to the Southwest Florida Water Management District, whereas industrial and publicsupply water withdrawals must be reported. Estimates of use are difficult to make because of variability in use seasonally and areally depending on weather and soil conditions.

In 1978, the benchmark farm program evolved from the water-use project and previous studies as a method for collecting more accurate irrigation water-use data. The benchmark farms are representative farms growing various crops that are closely monitored to help establish monthly water-application rates. These application rates are applied to the total crop acreage in the water management district to calculate total irrigation water use. Tropical fish ponds and golf courses are classified as crops in this report.

The benchmark farms include 18 citrus groves that were inventoried in 1970 as part of an earlier cooperative project between the U.S. Geological Survey and the Southwest Florida Water Management District. Two reports (Robertson and Mills, 1974; Robertson and others, 1978) on ground-water withdrawals in the upper Peace River and upper Alafia River basins resulted from that earlier study. The groves were reinventoried in 1978 and added to the current network of benchmark farms.

The purpose of this report is to present irrigation water-use data for selected farms and to show how these data are used to estimate total water use for irrigating various crops in southwest florida. The study area includeg all of the Southwest Florida Water Management District and is about $10,000 \mathrm{mi}^{2}$ in size (fig. 1). The initial emphasis on benchmark farm locations was in Hillsborough, Manatee, and Polk Counties. As the program continues, new farms are being added in surrounding counties (fig. 2).

Water-use data presented are shown as inches of water applied per acre per month. There is considerable variability in application rates. All farms withdraw ground water from highly productive limestone aquifers except farms at sites 58 and 77, which withdraw ground water from shallow sand aquifers, and farms at sites 54 and 75, which withdraw surface water (fig. 2). Rainfall data for 12 stations were collected to help interpret variability in water application throughout the study area.

\section{CRITERIA FOR SELECTING A BENCHMARK FARM}

Current efforts in developing a network of benchmark farms are directed toward monitoring a variety of crops. Broad areal coverage is also desirable. To meet these needs several farms may be selected for possible inclusion in the benchmark farm program.

When permission of an owner (irrigator) is obtained for use of his well in the benchmark farm program, several criteria must be met before the farm can be selected for inclusion in the study. First, the farm has to be representative of other farms in the study area so that the water-use data will have transfer value. Factors such as crop type, soil type, topography, and type of irrigation system must be similar to those used at other farms. Irrigation pumpage 


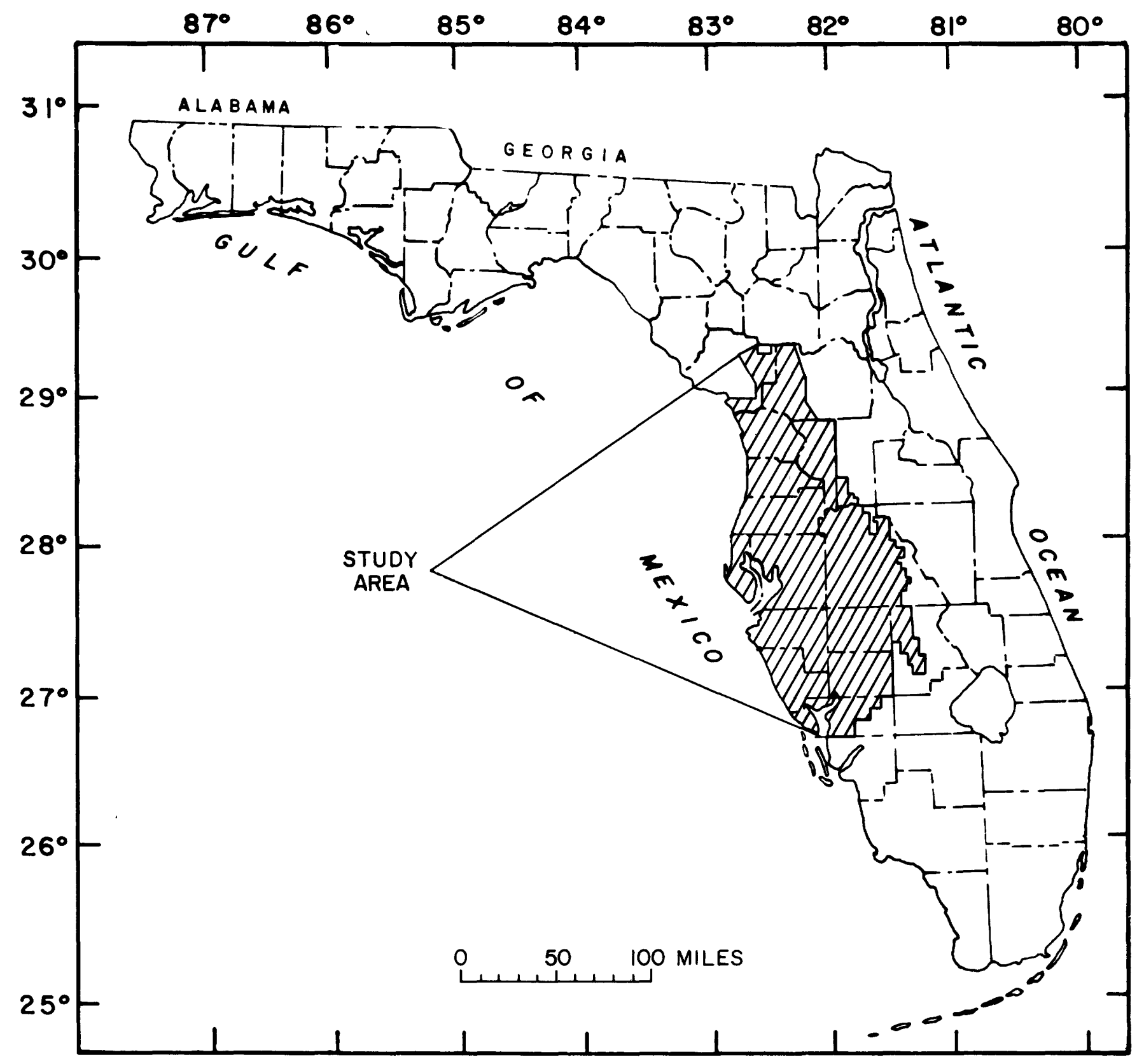

Figure 1.--Location of study area. 


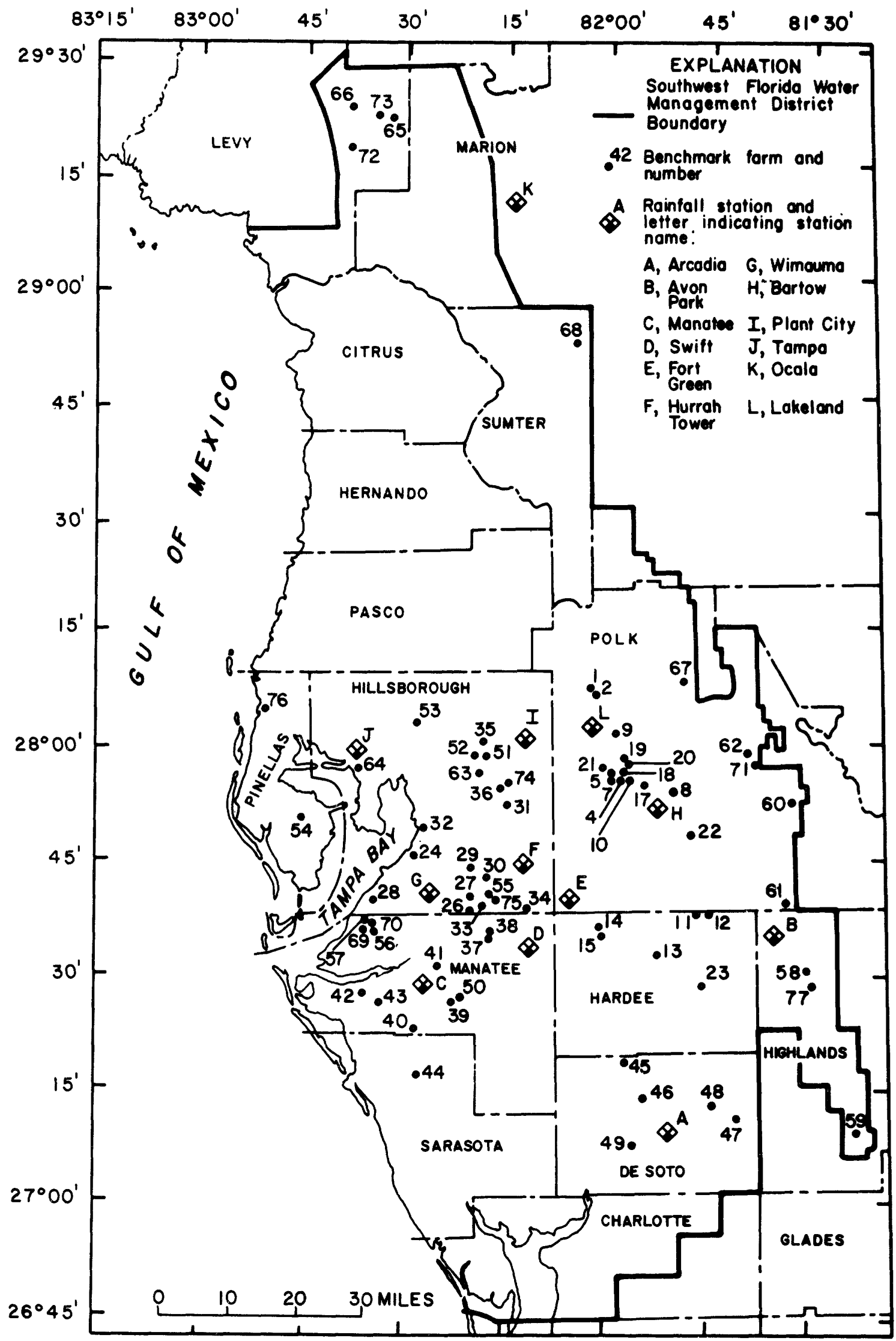

Figure 2.--Location of benchmark farms and rainfall stations. 
must be measurable. Pump discharge must be nonturbulent in order to obtain accurate discharge measurements using a sonic flow meter. Sections of discharge pipe that are level, above ground, and free from elbows, flanges, and tees are best for maintaining nonturbulent flow.

The study identifies water use by specific crops. Hence, the irrigation source (ground or surface water) must irrigate one crop exclusively unless a method exists for distinguishing the amount of water applied to different crops from the same source. If a pump is electrically powered, meter readings are used to estimate irrigation pumpage. The meter must register only power consumed by the pump.

\section{ESTABLISHING A BENCHMARK FARM}

After a farm is selected for monitoring, it is assigned a site number, and data about the farm, crop, water source, and pump are collected and stored in computer files. Farm data include location and description. Crop data include type, growing season, number of irrigated acres, and type of irrigation system. Well data include location, depth, casing, and diameter.

Pump data include make, horsepower, power source, and pumping (discharge) rate. The pumping rate, in gallons per minute or gallons per hour, is determined by either the trajectory method (Anderson, 1973, p. 156), a saddle (inline) flow meter, or a sonic flow meter. The trajectory method estimates the pumping rate by measuring the vertical and horizontal distance of flow from an open discharge pipe. It is the least accurate of the three methods. Several saddle flow meters have been supplied and installed by the Southwest Florida Water Management District and directly record total gallons pumped. However, the relative expense and difficulties in installation of these meters have limited their use to existing installations. Pumping rates determined by a sonic flow meter enable accurate discharge measurements without cutting or drilling a hole in the discharge pipe. The sonic flow meter and sonic flowmeter transducers attached to pump discharge pipe are shown in figure 3.

After a pump is rated, the time of operation or amount of electrical power used must be determined to compute water usage. For electric pumps, field measurements are made to determine the amount of water that is pumped per kilowatt hour of electrical energy used. Subsequent data on energy usage, based on meter readings, are then applied to compute the amount of water used. If the pump is powered by a diesel engine, a vibration-time totalizer (VTT) is installed on the pump. The VTT is activated by pump vibration and records pumping time in hours. For sites monitored by saddle flow meters, discharge is measured directly from meter readings. Saddle flow meter, electric meter, and vibration-time totalizer used for recording pumpages are shown in figure 4. Some pumps that are powered by diesel engines are equipped with built-in clocks that record engine running time. The clocks are read periodically and used as back-up for the other methods of measurement, particularly the VTT's, which sometimes fail because of moisture penetration. 


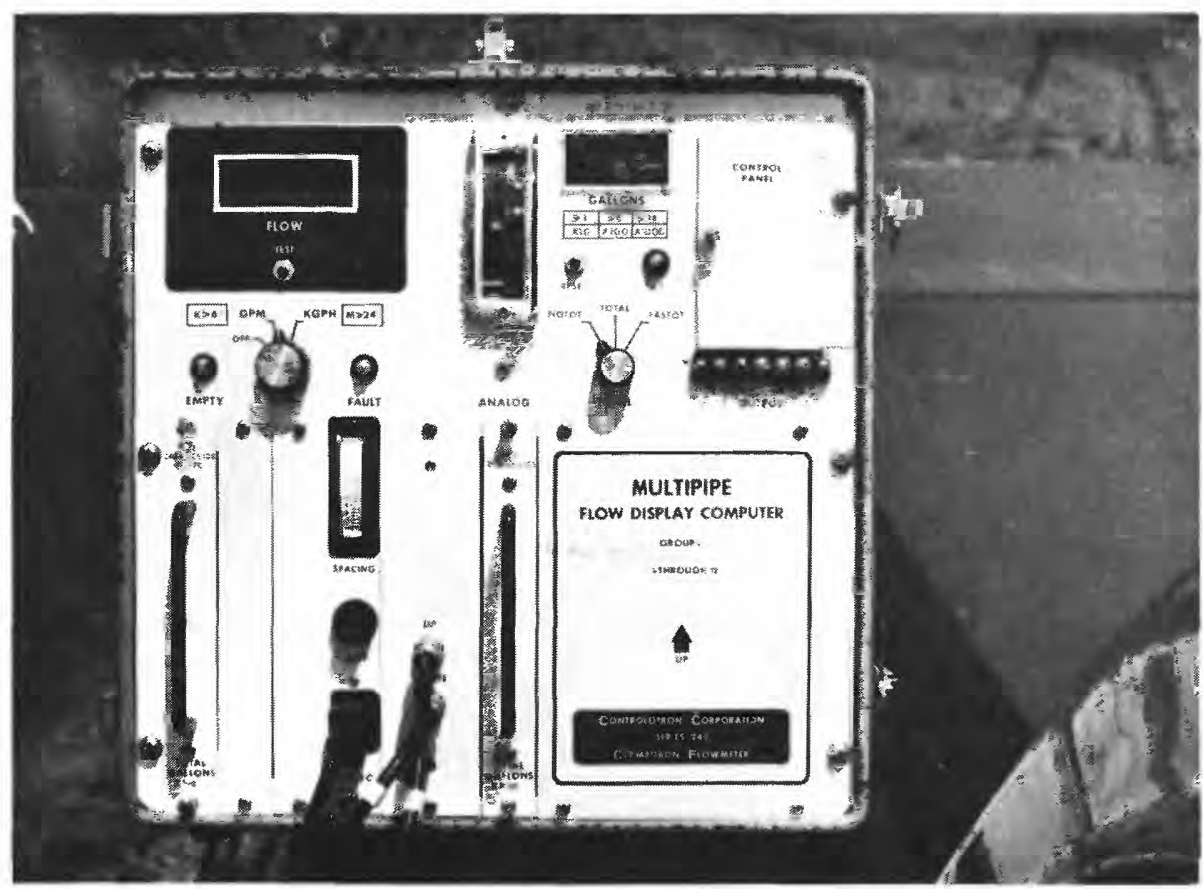

A. Sonic flow meter.

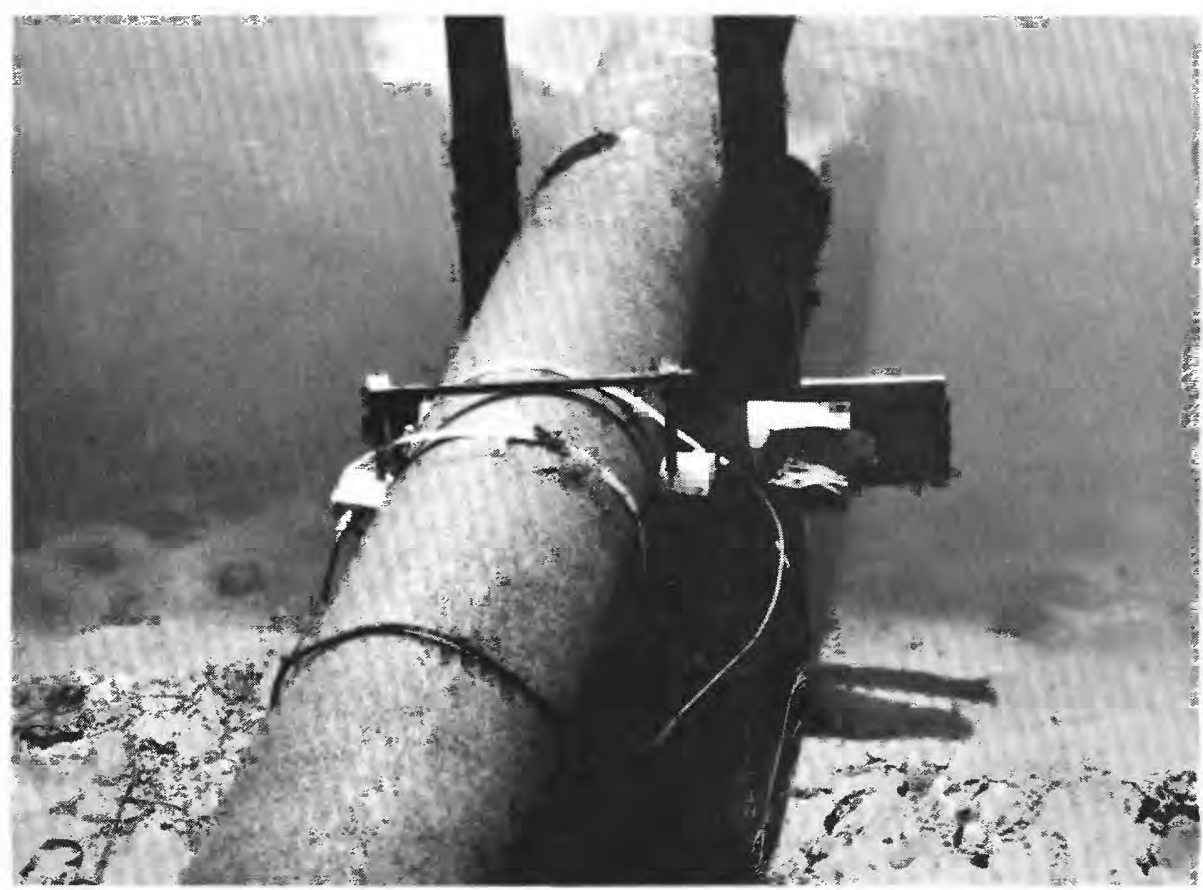

B. Sonic flow-meter transducers attached.

Any use of trade names and trademarks in this publication is for descriptive purposes only and does not constitute endorsement by the U.S. Geological Survey.

Figure 3.--Sonic flow meter used for measuring pump discharge. 


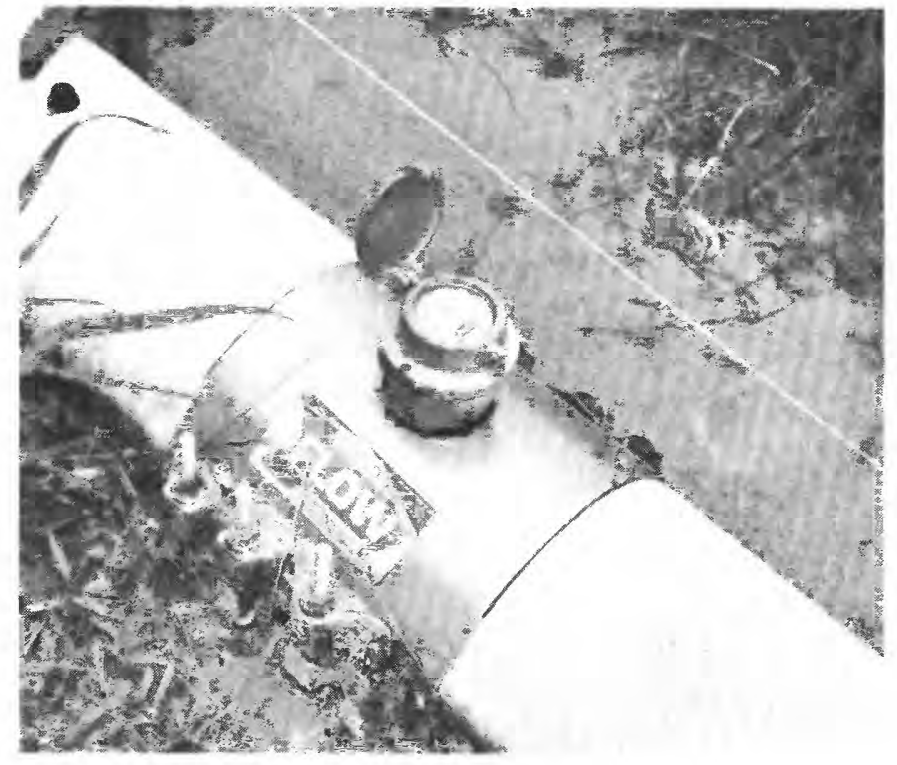

A. Saddle flow meter.

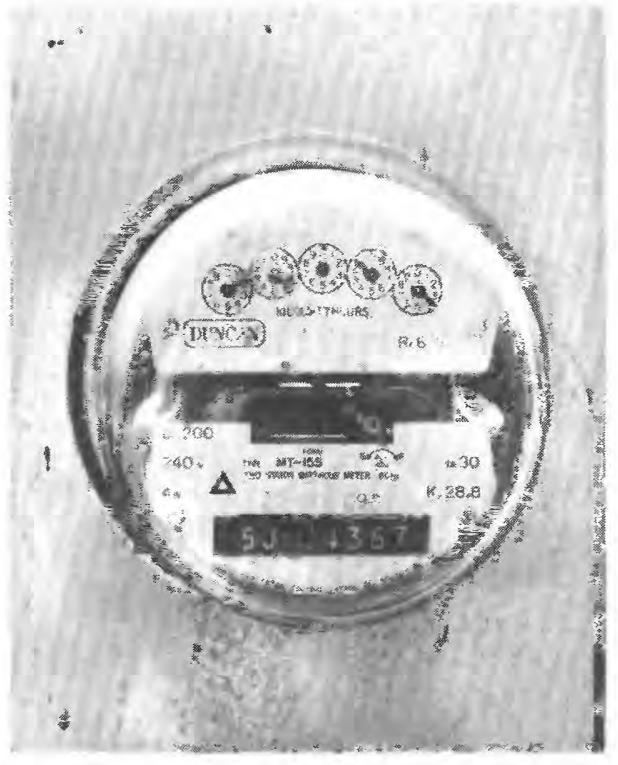

B. Electric meter.

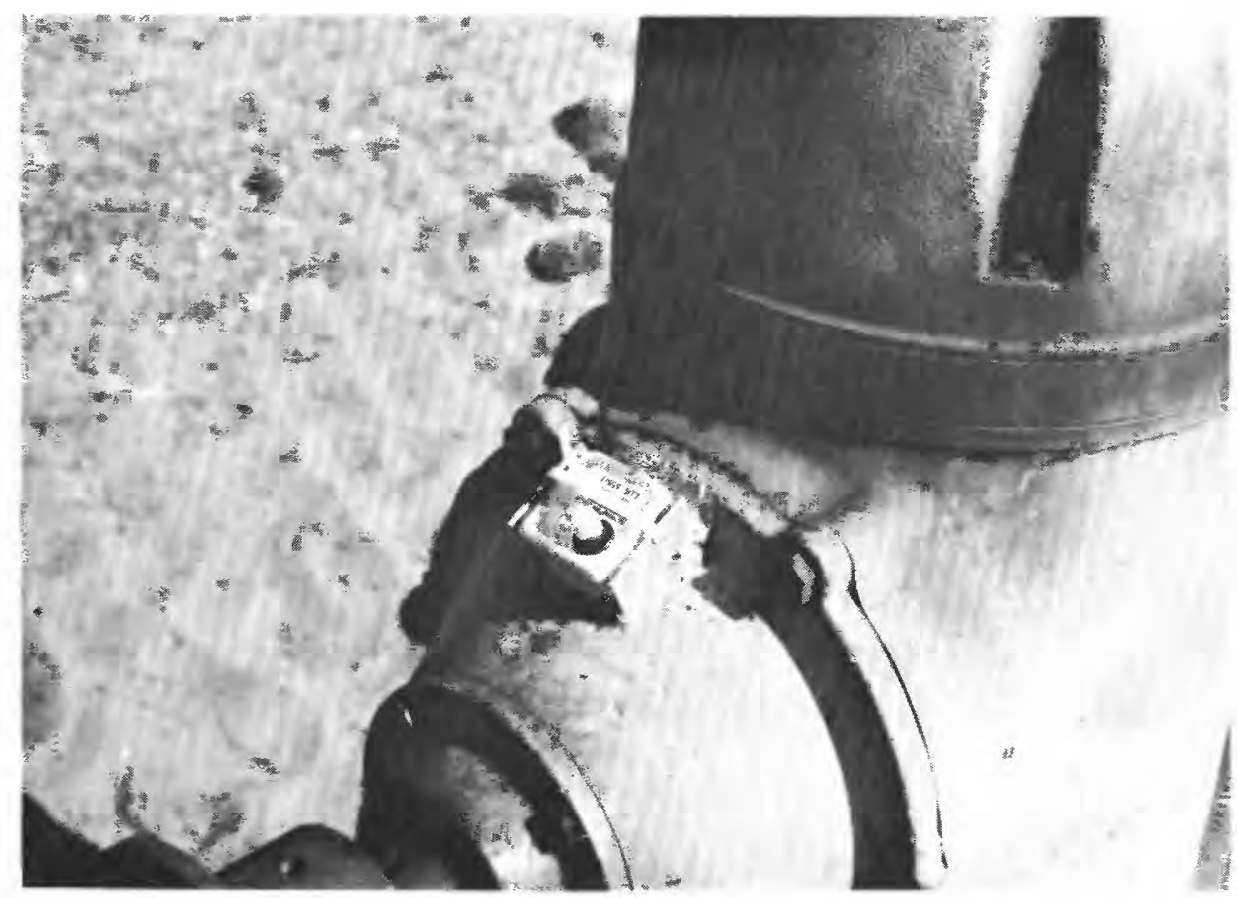

C. Vibration-time totalizer.

Any use of trade names and trademarks in this publication is for descriptive purposes only and does not constitute endorsement by the U.S. Geological Survey.

Figure 4.--Saddle flow meter, electric meter and vibration-time totalizer used for recording pumpage. 
Data are collected monthly from the benchmark farms. Vibration-time totalizers and electric meters are read to determine pumping time or electrical power usage. Pumping time is multiplied by the pumping rate to determine the volume of water pumped per month. Similarily, power usage is converted to vo1ume of water pumped. Readings from saddle flow meters provide pumpage volumes directly. The volume pumped per month at each farm is divided by the number of acres irrigated to obtain the amount of water applied in inches per acre.

\section{IRRIGATION SYSTEMS}

Irrigation systems used at the benchmark farms represent the common types found in southwest Florida. Photographs of some of the systems are shown in figures 5-7. Definitions of the systems as used in this report are listed below:

Seepage: Water is conveyed from the source and distributed to the crop through open ditches (also called flood or open-ditch irrigation, fig. 5a).

Semiclosed: Water is conveyed from the source through closed pipe and distributed to the crop through open ditches between crop rows (fig. 5b).

Closed pipe: Water is conveyed from the source and distributed to the crop through closed pipe (fig. 5c). This system is used almost exclusively for fish farms.

Drip: Water is conveyed from the source through closed pipe and distributed to the crop by dripping at land surface near each plant through special emitters set in small diameter plastic pipe or tubing (fig. 6a).

Jet: Water is conveyed from the source through closed pipe and distributed to the crop at land surface near each plant through small spray emitters (jets) set in small diameter plastic pipe or tubing (fig. 6b).

Overhead: Water is conveyed from the source through closed pipe and distributed to the crop through nozzles 15 to 20 feet above land surface (fig. 6c).

Sprinkler: Water is conveyed from the source through closed pipe and distributed to the crop through nozzles 1 to 2 feet above land surface (fig. 7a).

Volume gun: Water is conveyed from the source through closed pipe or hose and distributed to the crop through a large rotating nozzle (fig. $7 b$ ).

Subirrigation: Water is conveyed from the source through closed pipe and distributed to the crop through underground tile.

Travel gun: A volume gun that travels the length of the crop row while irrigating. 


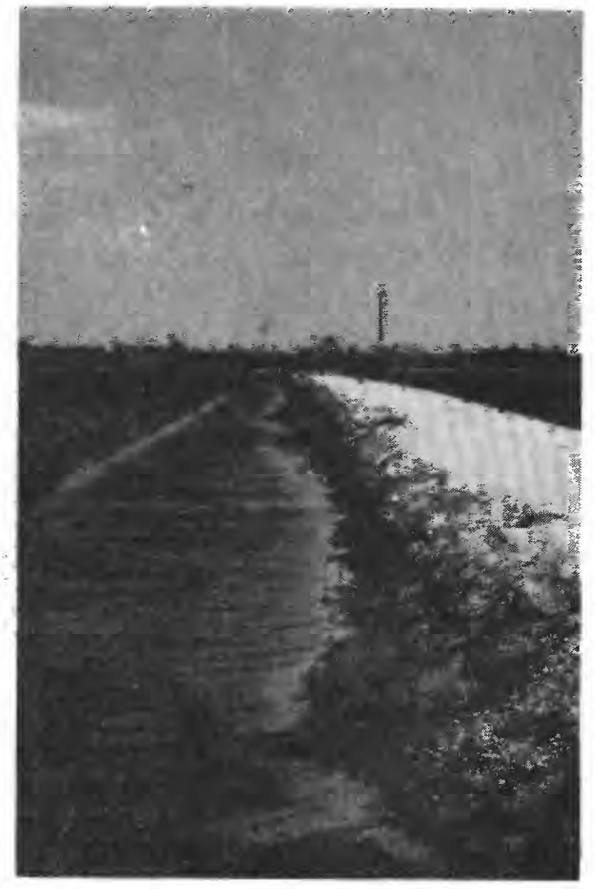

A. Seepage.

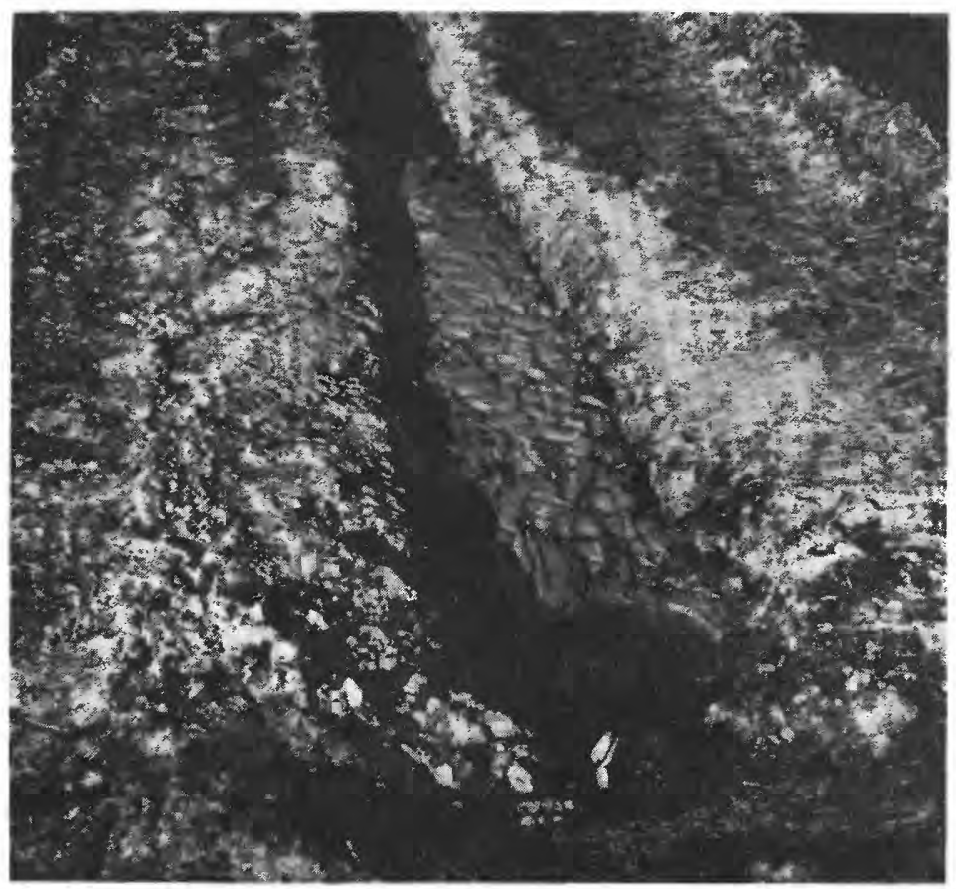

B. Semiclosed.

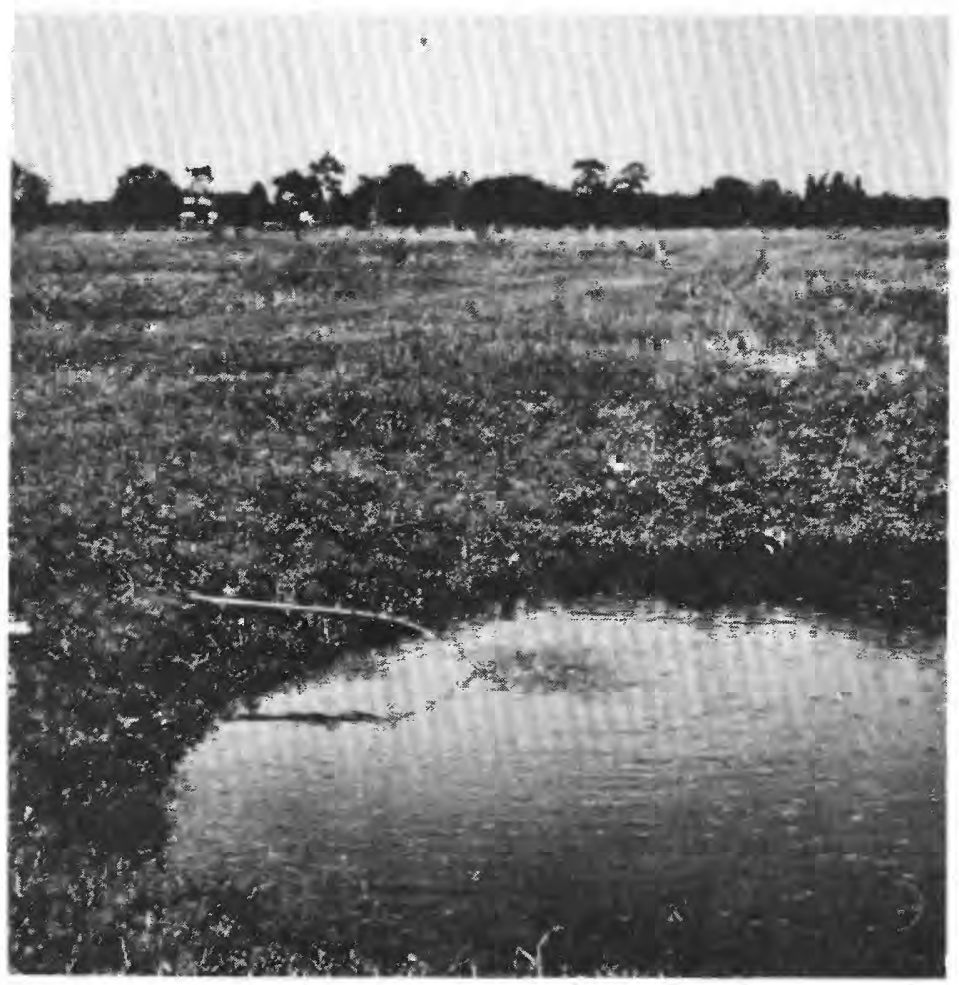

C. Closed pipe.

Figure 5.--Seepage, semiclosed, and closed-pipe irrigation systems. 


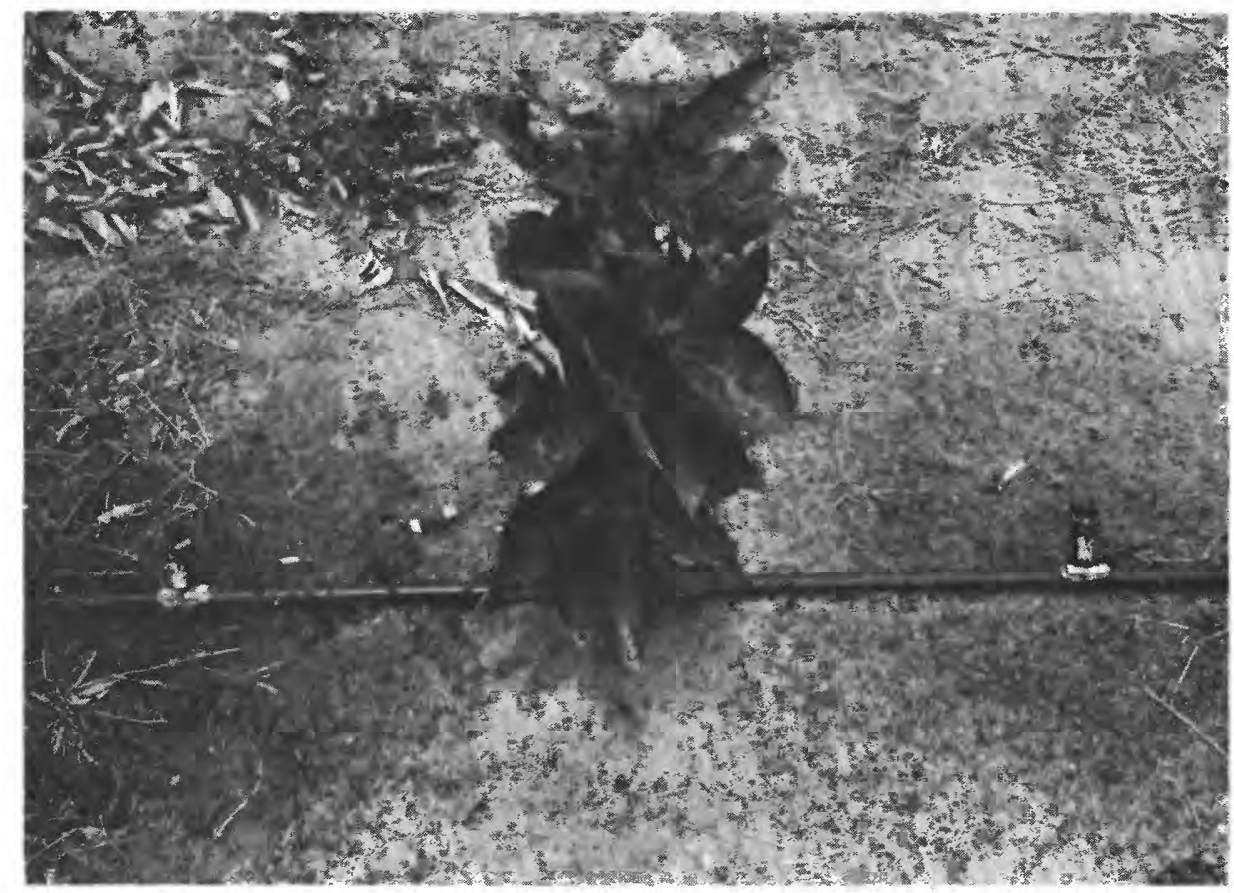

A. Drip.

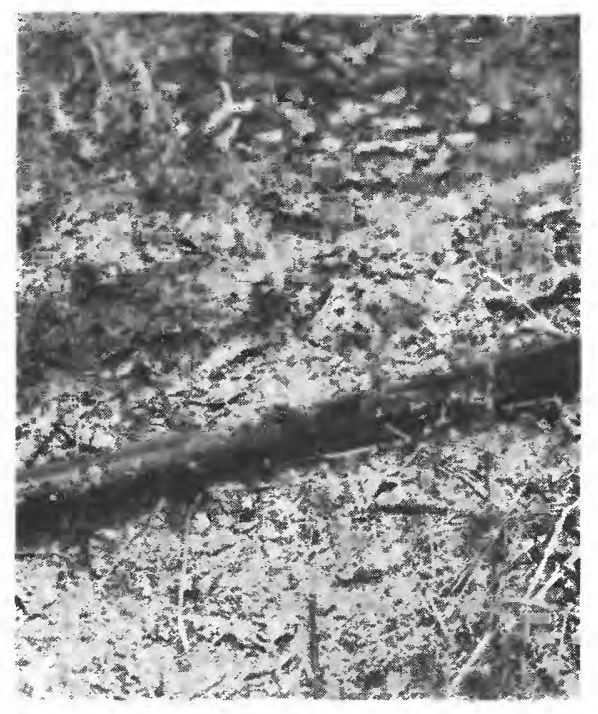

B. Jet.

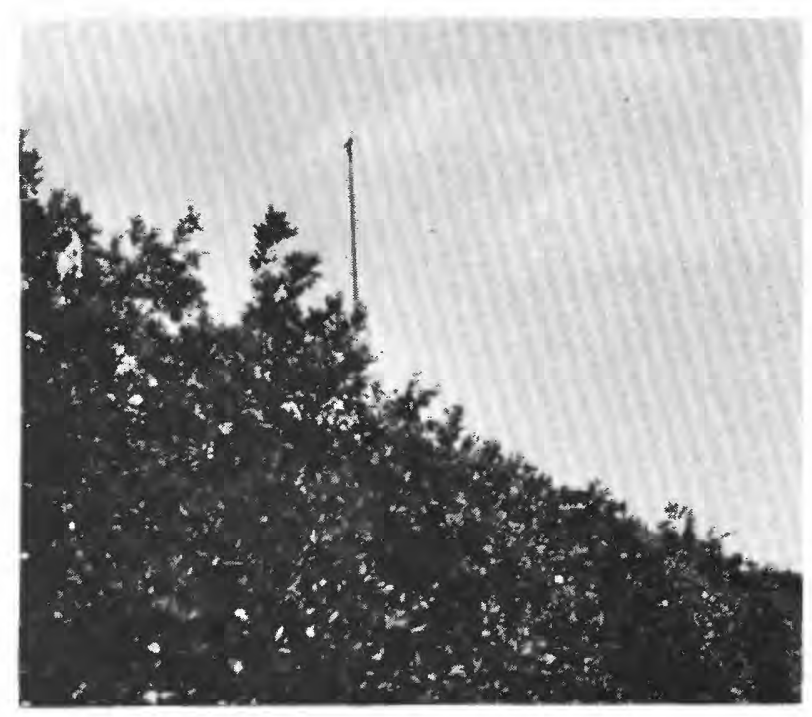

C. Overhead

Figure 6.--Drip, jet, and overhead irrigation systems. 


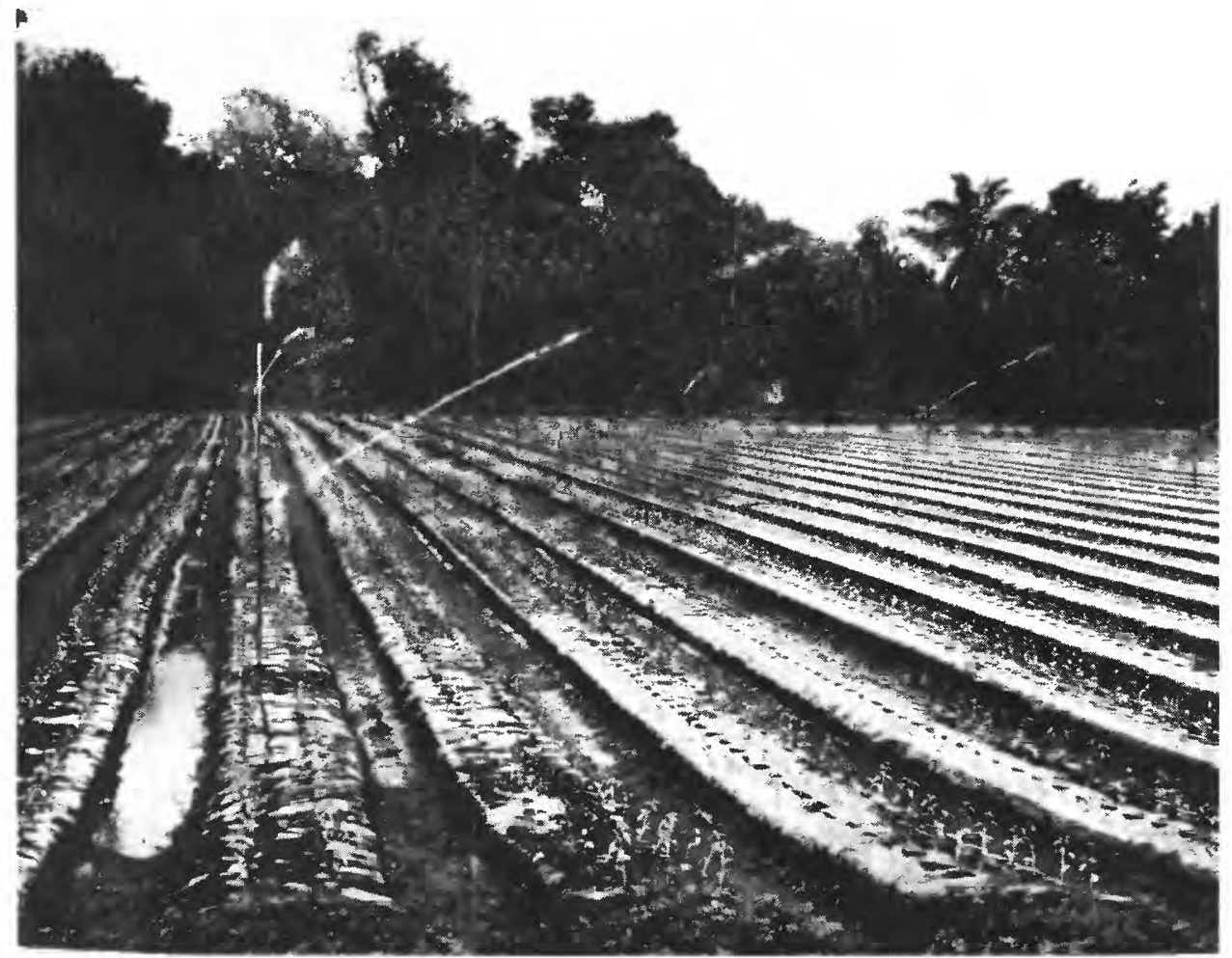

A. Sprinkler.

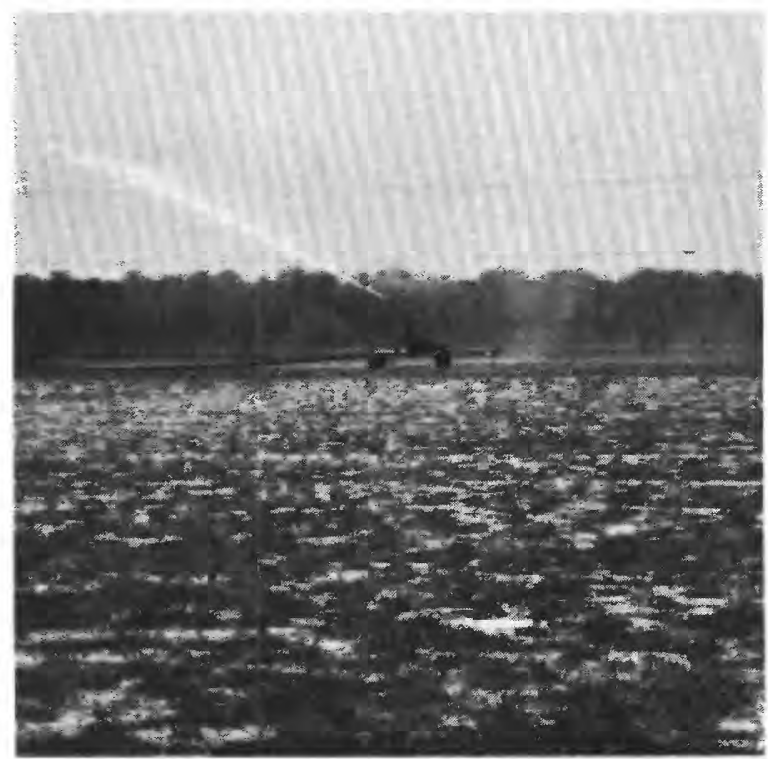

B. Volume gun.

Figure 7.--Sprinkler and volume-gun irrigation systems. 
Table 1 presents records of 74 benchmark farms in southwest Florida. Data include site number, county, township and range, year, season, crop, acres, irrigation system, monitoring method, and inches of water applied per acre per season. Most data are for 1978-80, but data for 18 citrus sites go back to the early 1970's. Sites are listed numerically and generally follow the order of their inclusion into the benchmark farm program. Data are presented for 36 citrus groves, 1 cucumber farm, 4 golf courses, 3 nurseries, 6 pastures, 1 peanut farm, 3 sod farms, 8 strawberry farms, 9 tomato farms, 2 tropical fish farms, and 2 watermelon farms (site 51 grows both strawberries and tomatoes). Although water-application rates shown in table 1 are annual or season totals, most data were collected monthly as reported in table 2. The monthly data are segregated by crop and irrigation system. Monthly subtotals are not shown where data were collected bimonthly, quarterly, or seasonally. Rounding procedures caused slight differences in the inches per acre totals between tables 1 and 2. Although data in the tables are reported to the nearest 0.01 in/acre, most data are probably accurate only within 10 percent.

Table 3 shows water-use data for 1980 as segregated by crop. Each crop is grouped by irrigation system, and low, mean, and high application rates are listed. Mean rates are calculated by summing the rates for each site and dividing by the number of sites. Weighted means based on farm acreage were not used. Composite mean rates are presented for crops that have more than one type of irrigation system. More details on individual crops are presented in the next section.

Figures 8-10 present rainfall at 12 stations. Data include station name, year, month, and inches of rainfal1. Station locations are shown in figure 2 . Figures 11-13 present rainfall at selected stations and water applied (pumpage) at nearby benchmark farm sites. Generally, pumpage varies inversely with rainfal1. For example, monthly comparisons of rainfall with citrus irrigation records in figure 13 show that pumpage for citrus irrigation is less during months when rainfall is greater.

\section{WATER-APPLICATION RATES BY USE IN 1980}

Water-application rates for each crop monitored in 1980 are discussed in this section. During the spring season, mean water-application rates ranged from $3.8 \mathrm{in} /$ acre for cucumbers irrigated by a sprinkler system to $51.0 \mathrm{in} / \mathrm{acre}$ for tomatoes irrigated by semiclosed systems (table 3). During the fall season, mean water-application rates ranged from 3.8 in/acre for watermelons irrigated by a sprinkler system to 57.0 in/acre for tomatoes irrigated by semiclosed systems. Of the annual crops, peanuts irrigated with a volume gun system used the least water, averaging $3.1 \mathrm{in} / \mathrm{acre}$. Nurseries with sprinkler systems had the highest average water usage, $172.2 \mathrm{in} / \mathrm{acre}$. 


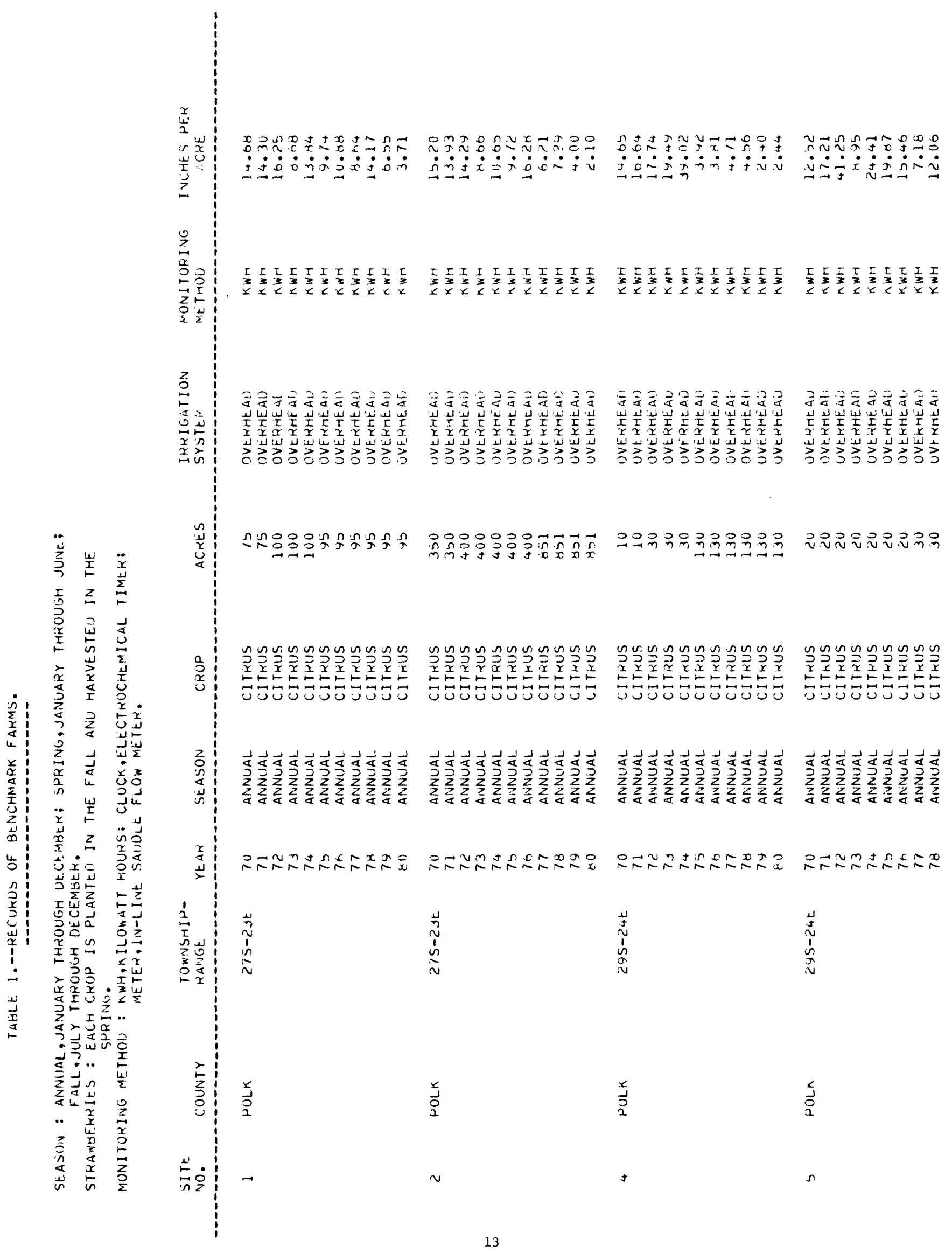




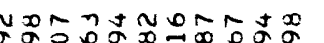

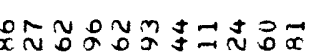

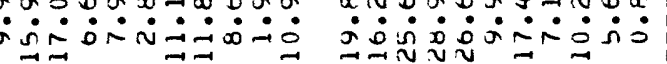

$\underset{2}{2}$

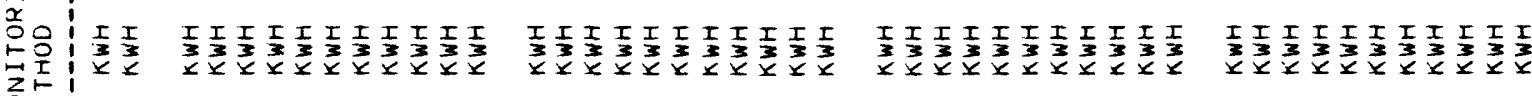

这

z

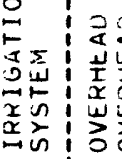

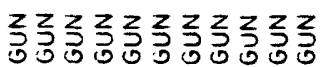

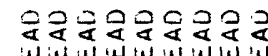

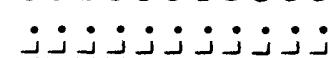

因

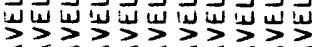

4
2

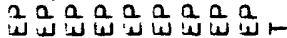

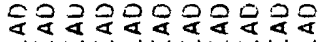

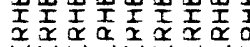

在

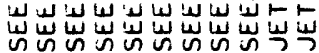

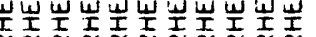

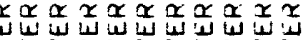

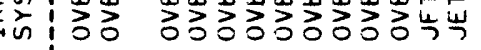

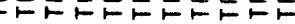

察

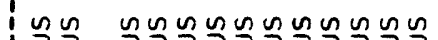

:

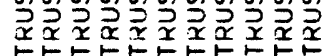

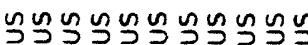

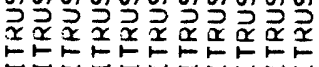

ผ

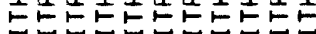

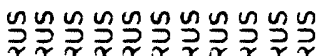

U气

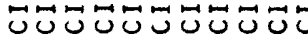

00000000000

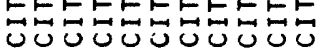

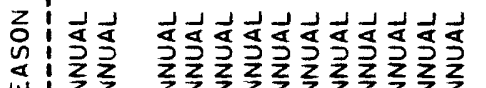

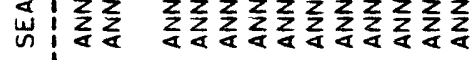

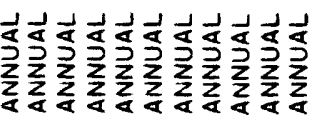

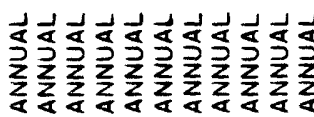

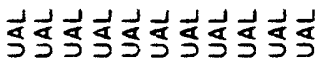

品

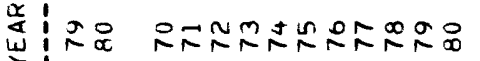

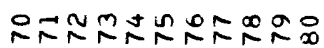

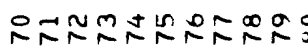

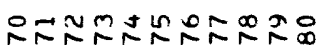

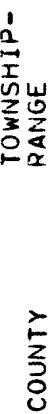

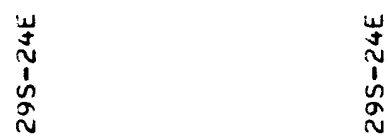

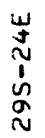

$\stackrel{u}{\sim}$

药完

$\stackrel{x}{\circ}$

r $\frac{x}{3}$

$\infty$ $\stackrel{u}{\sim}$

؛ัo

a 


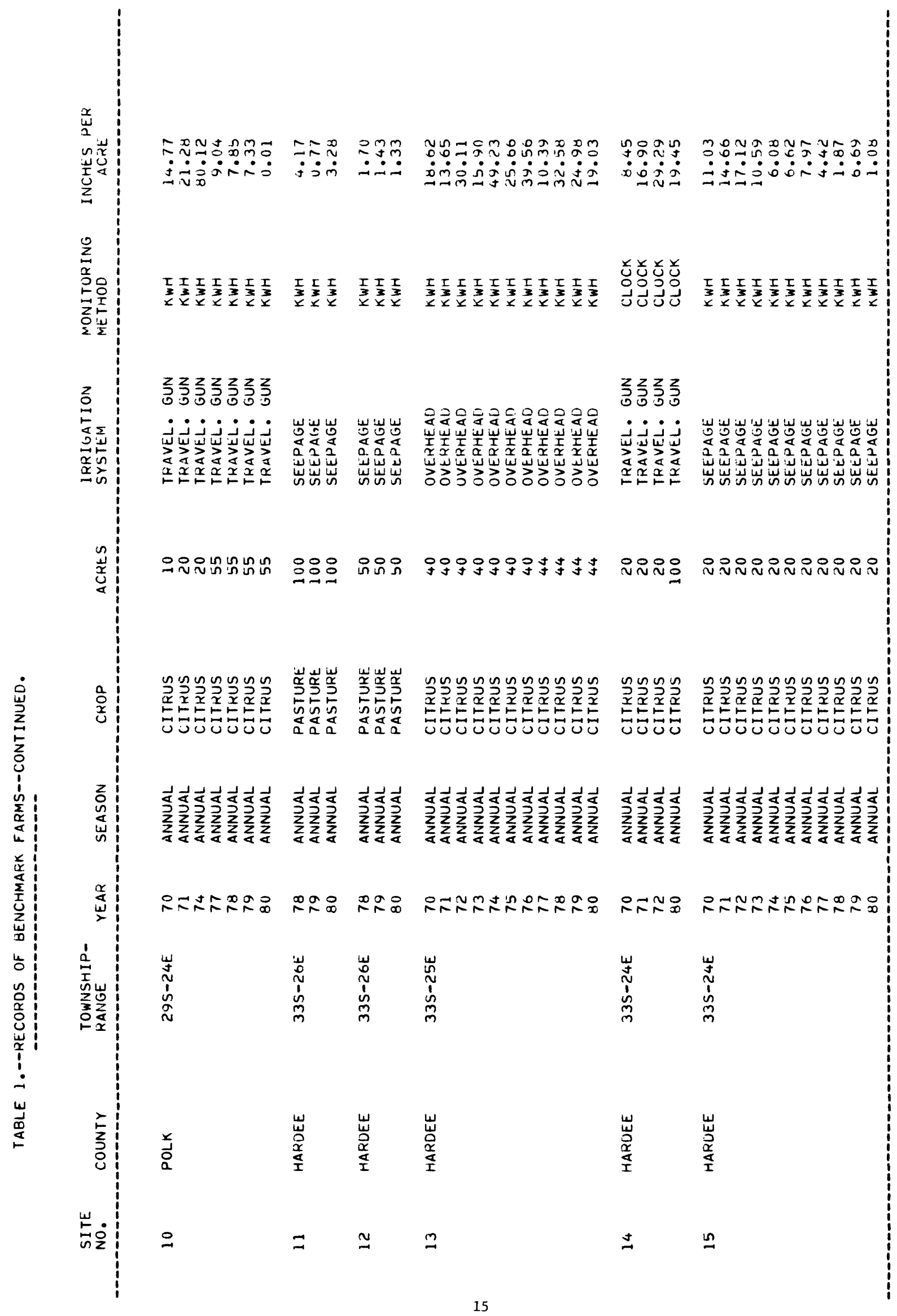




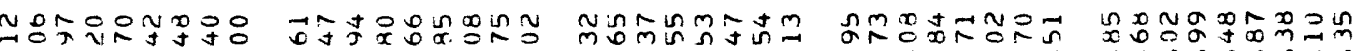

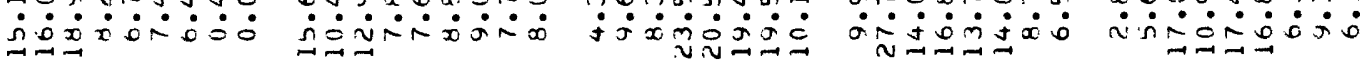

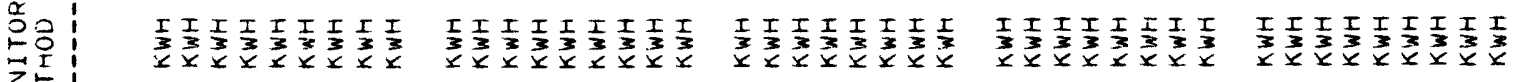

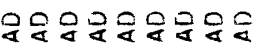

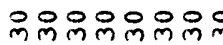

논윤ํํ뉴

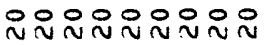

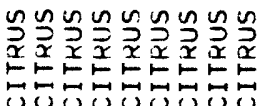 \\ non

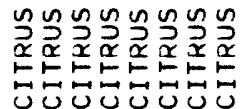

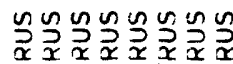

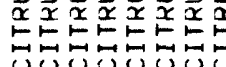

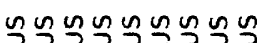

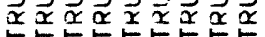

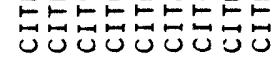

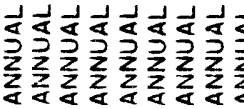

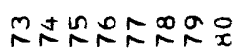

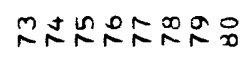

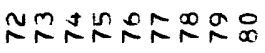

$\stackrel{x}{\circ}$

$\stackrel{\infty}{\sim}$ $\stackrel{x}{a}$

2
훙

요 $\vec{\sim}$

号 


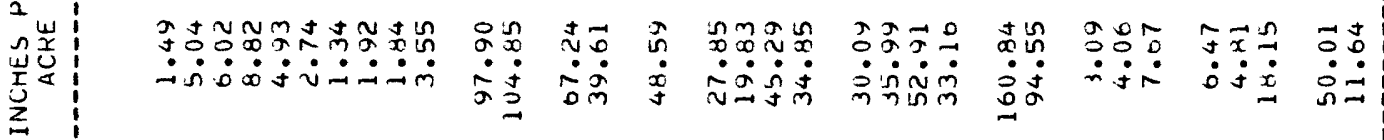

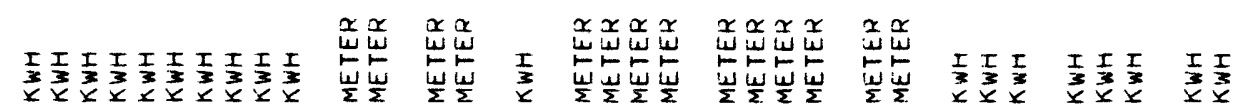

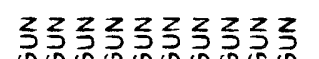

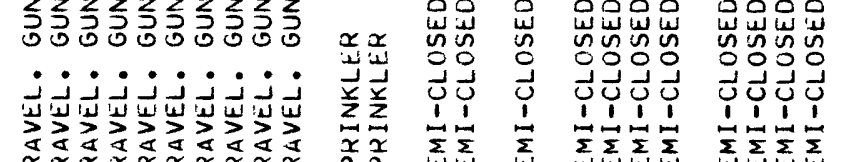

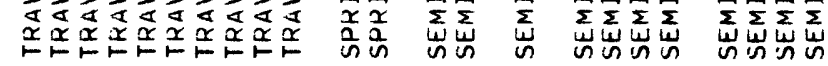

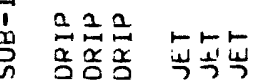

운

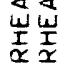

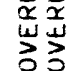

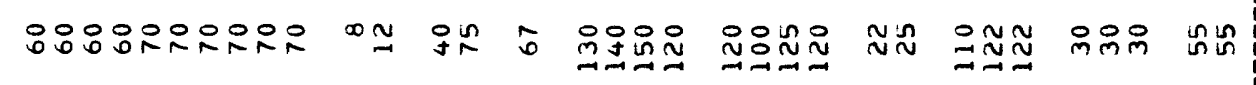

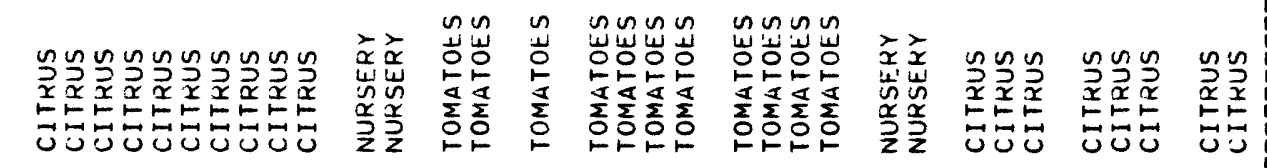

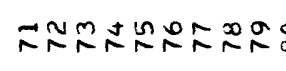

4
$\stackrel{1}{1}$
$\vdots$
$\stackrel{m}{0}$

綰。 峁

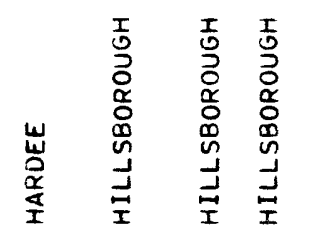

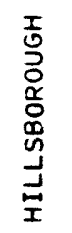

\begin{tabular}{l}
$I$ \\
5 \\
0 \\
0 \\
0 \\
0 \\
0 \\
0 \\
$د$ \\
$د$ \\
\hline 1
\end{tabular}

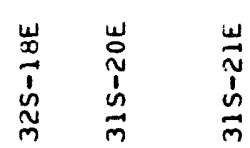

$\begin{array}{ll}\stackrel{\omega}{N} & \stackrel{\omega}{N} \\ \dot{n} & \tilde{n}\end{array}$

$\underset{\substack{a \\ a}}{\stackrel{x}{a}}$

$\stackrel{m}{\sim} \stackrel{\sim}{\sim}$

n

$\stackrel{\infty}{\sim}$

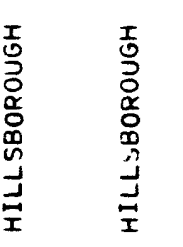

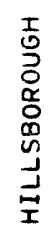

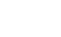


$\stackrel{x}{\mathrm{w}}$

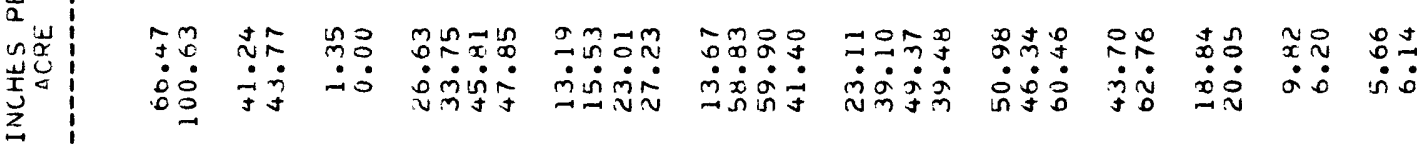

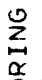

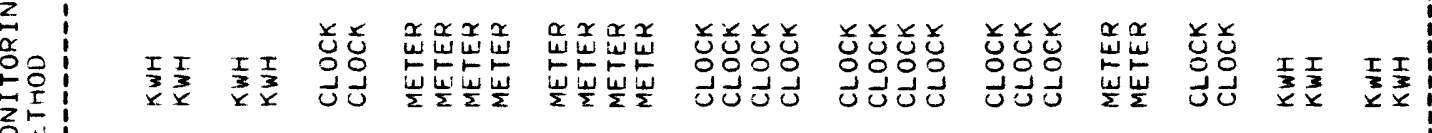

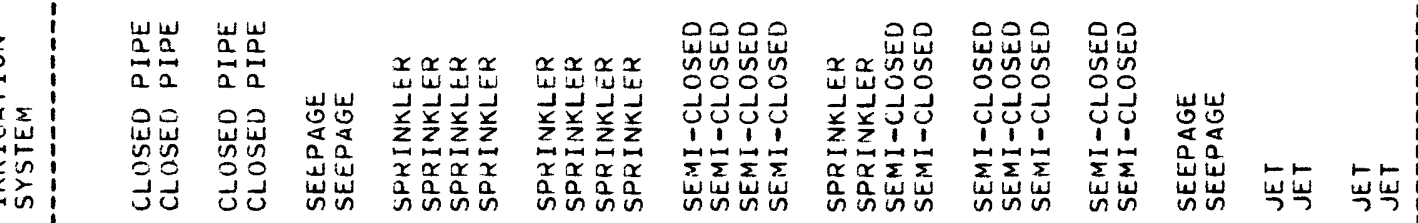

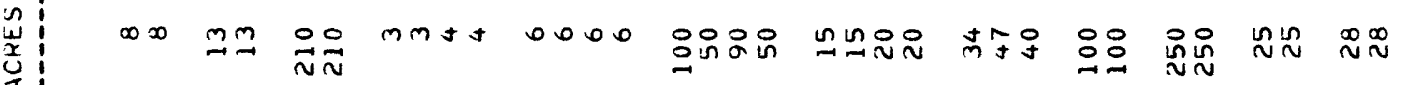

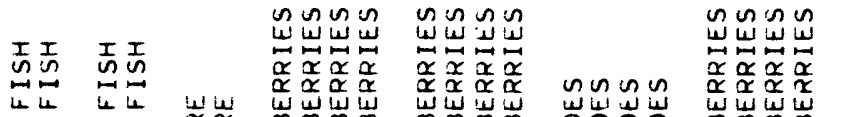

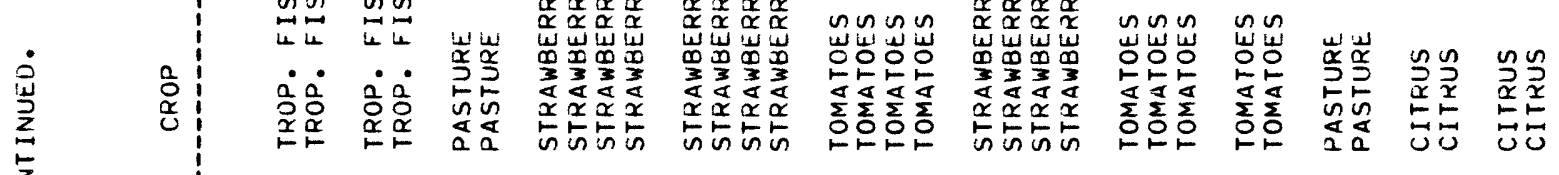

in:

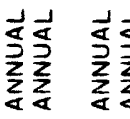

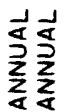

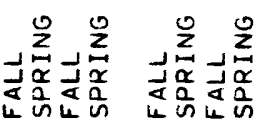

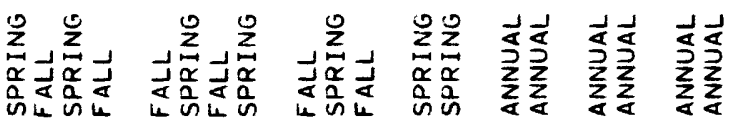

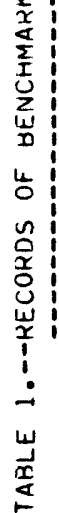

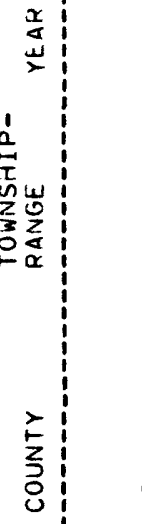

$\stackrel{a}{r}$

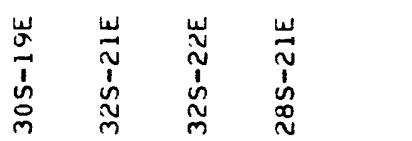

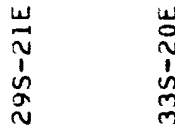

$\stackrel{\stackrel{u}{N}}{\stackrel{u}{\sim}}$

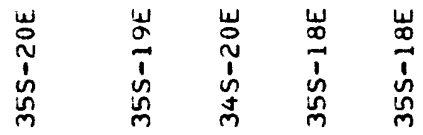

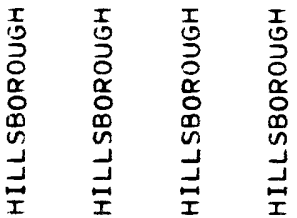

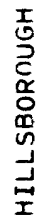

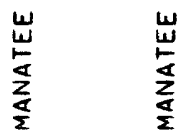

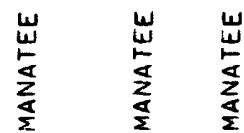

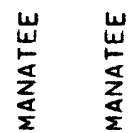

岁这

$\cong \stackrel{m}{m} \stackrel{m}{m} \stackrel{m}{m}$

n) $\quad \stackrel{\infty}{m}$

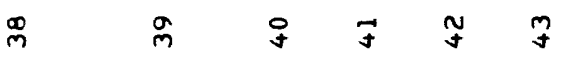

18

岕

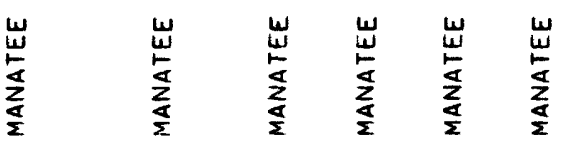




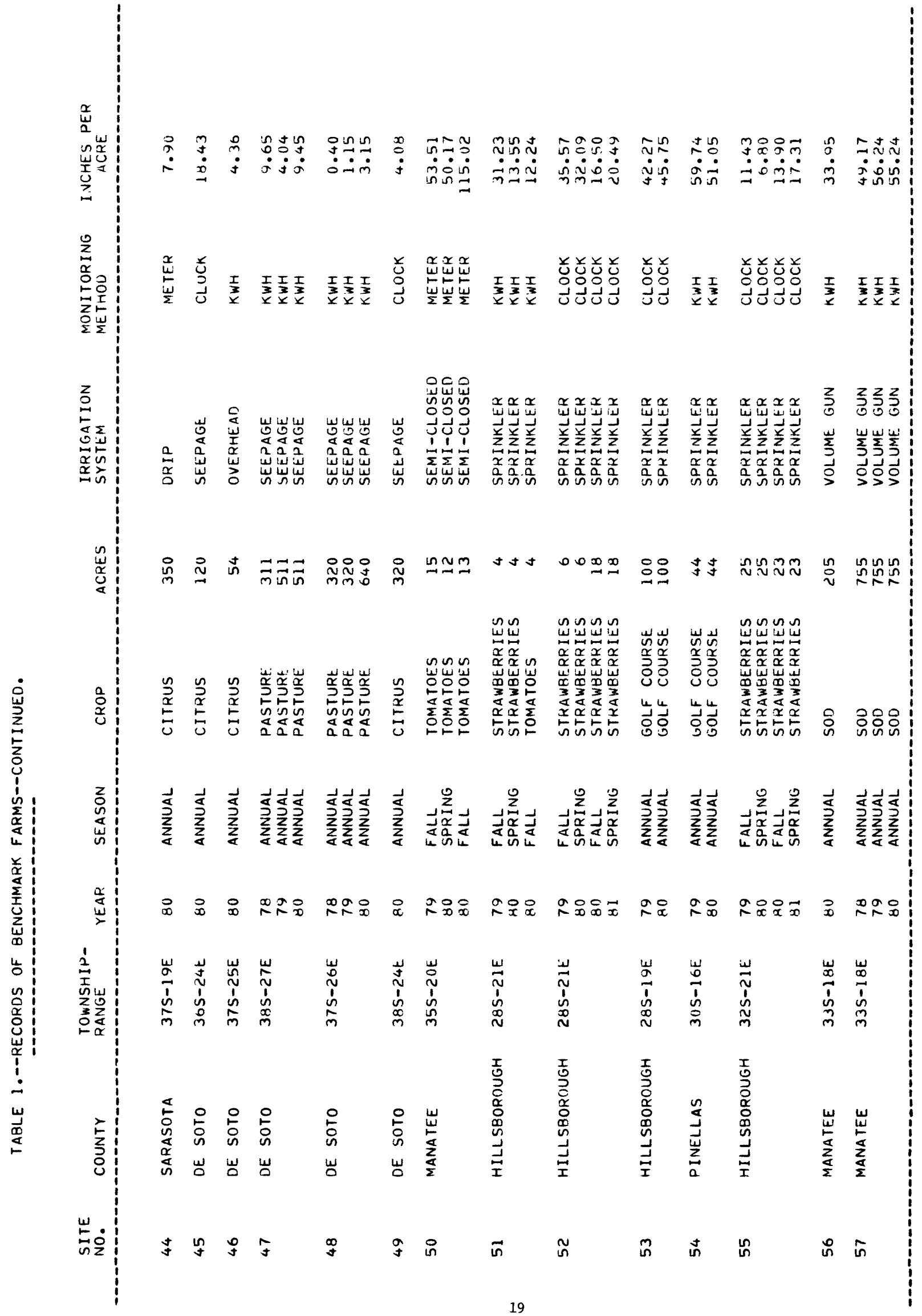




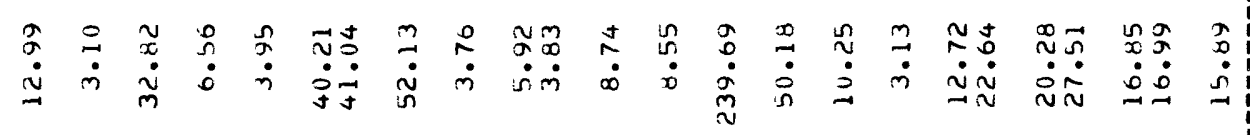

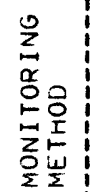

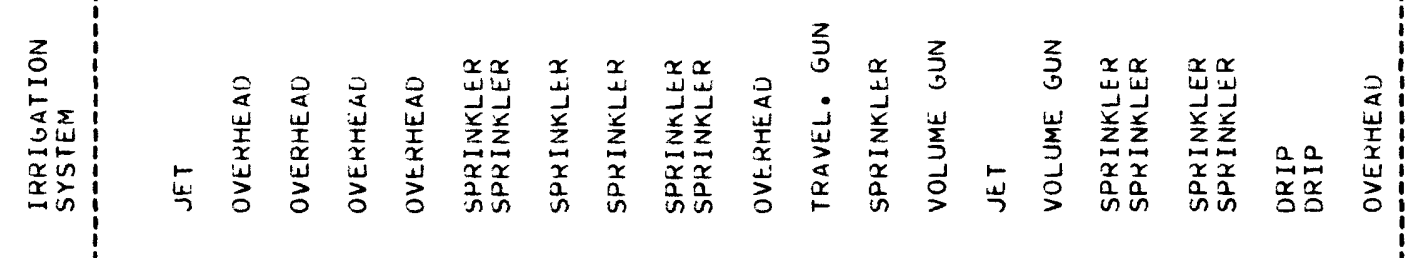

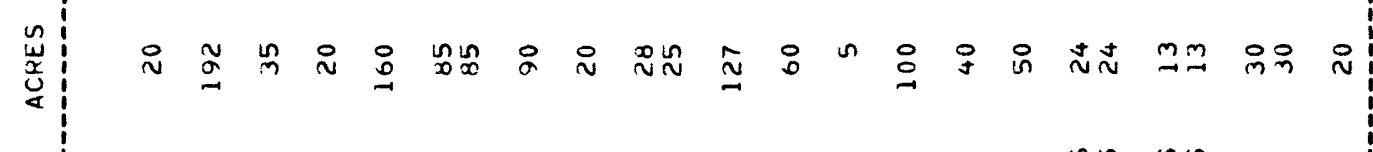

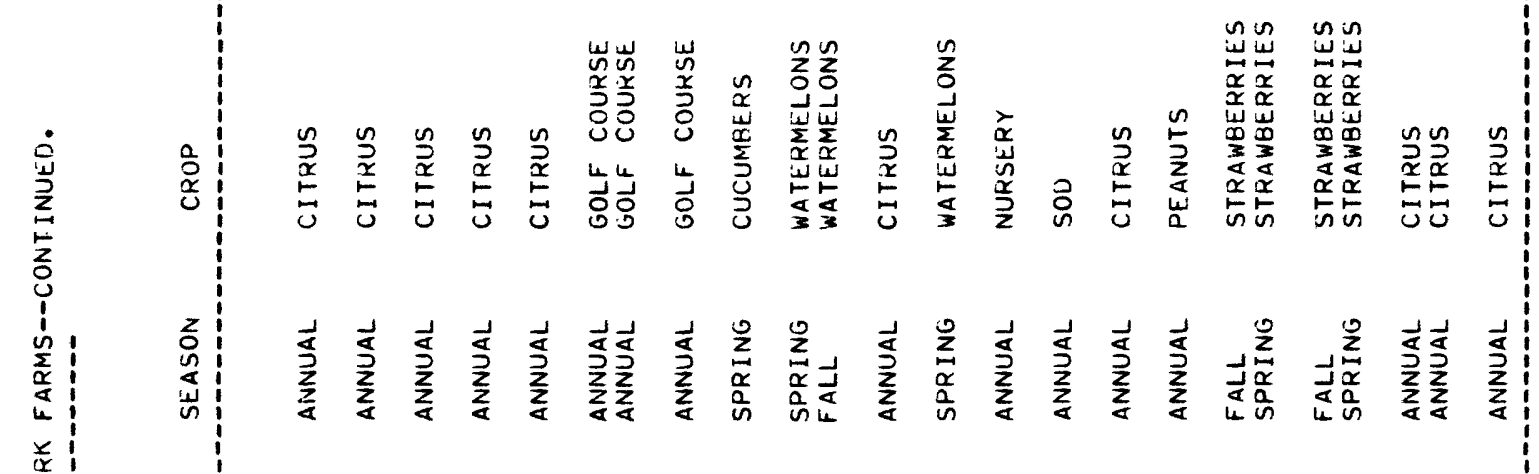

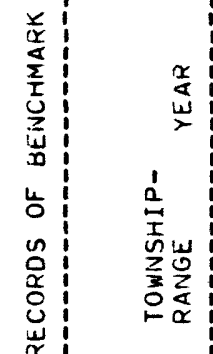

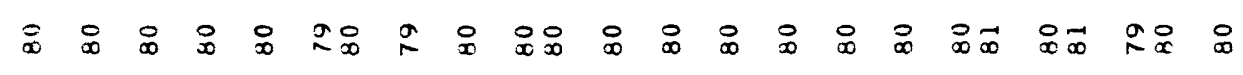

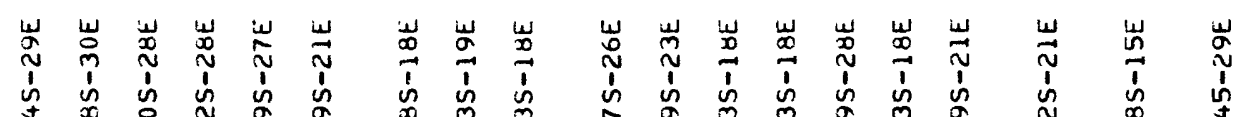

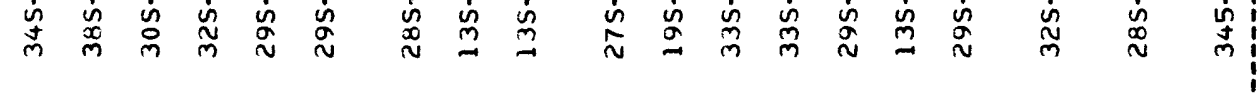

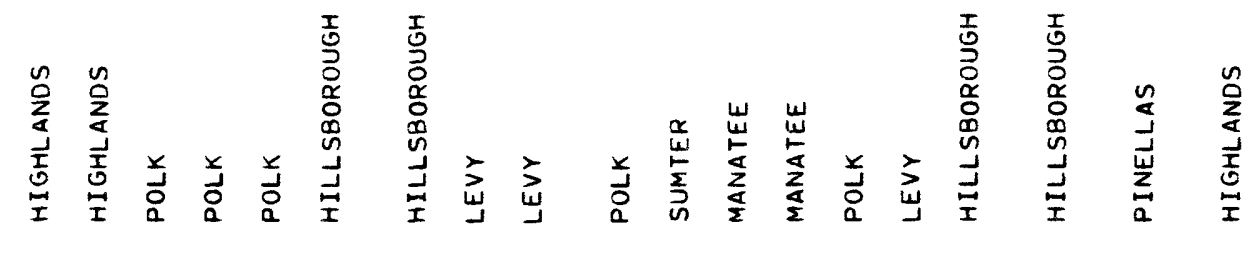

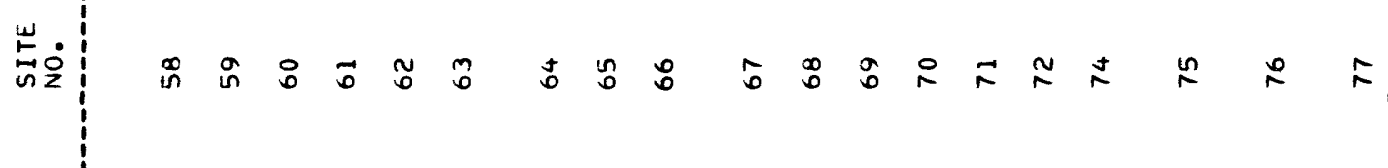




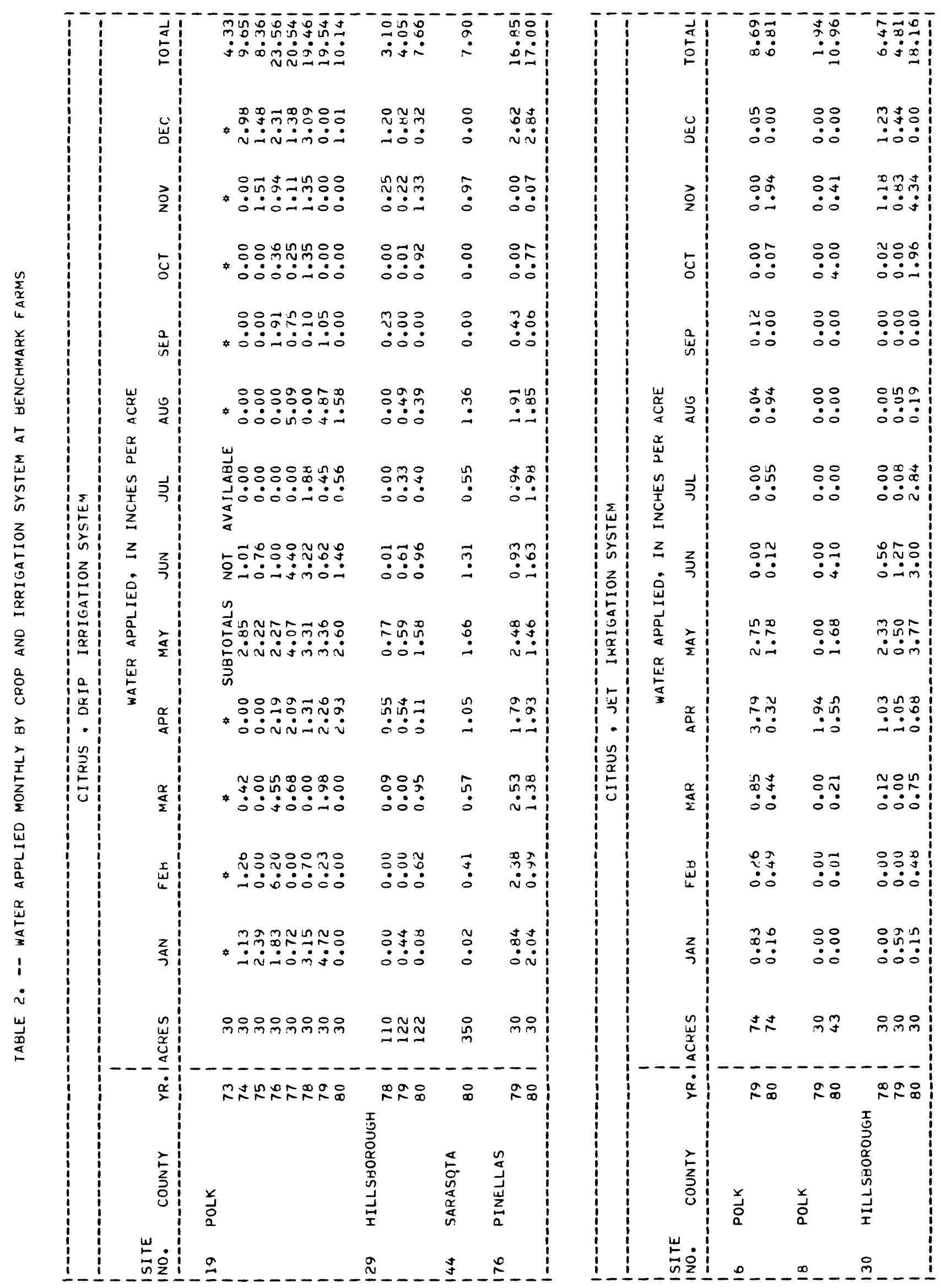



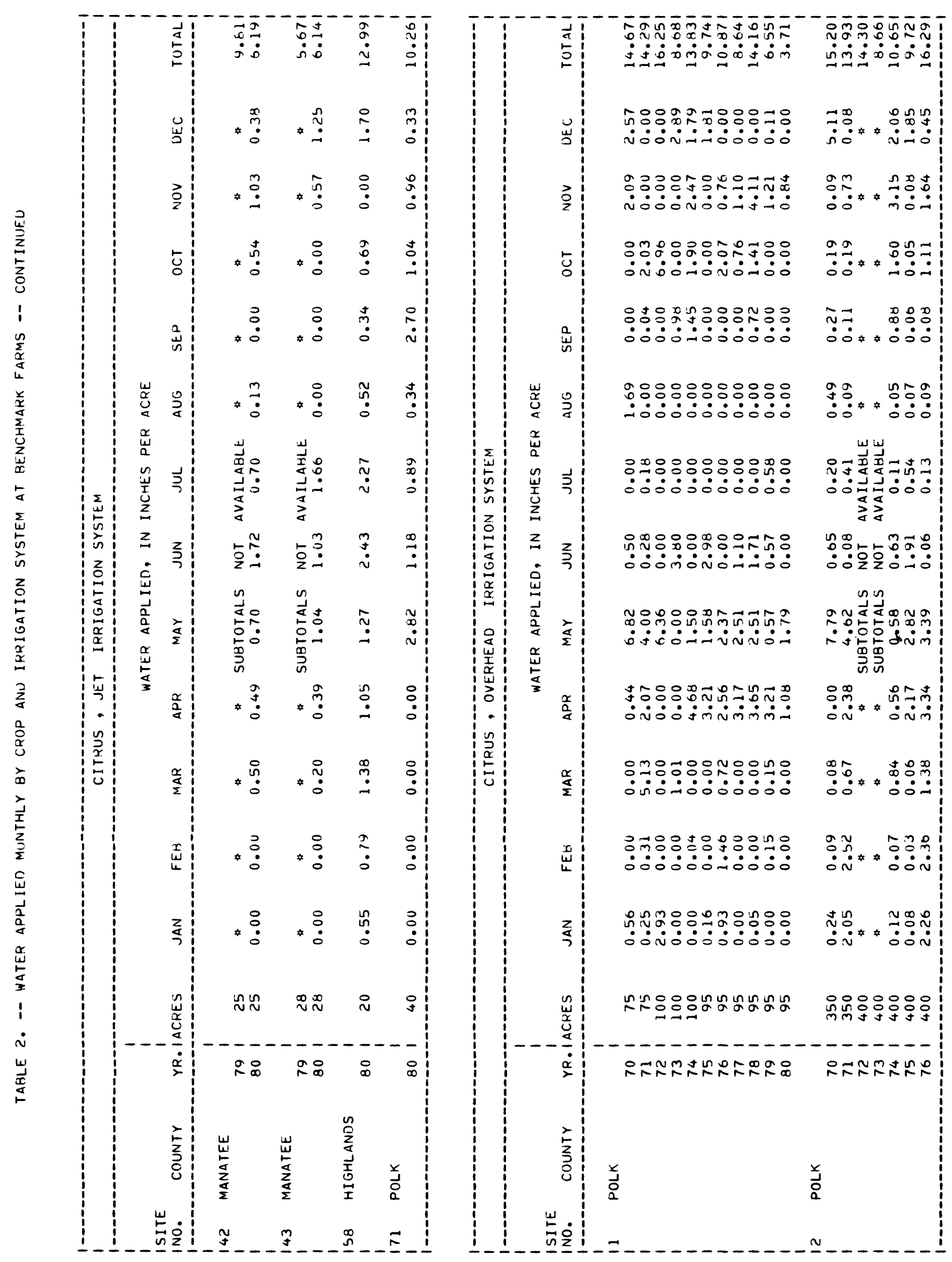


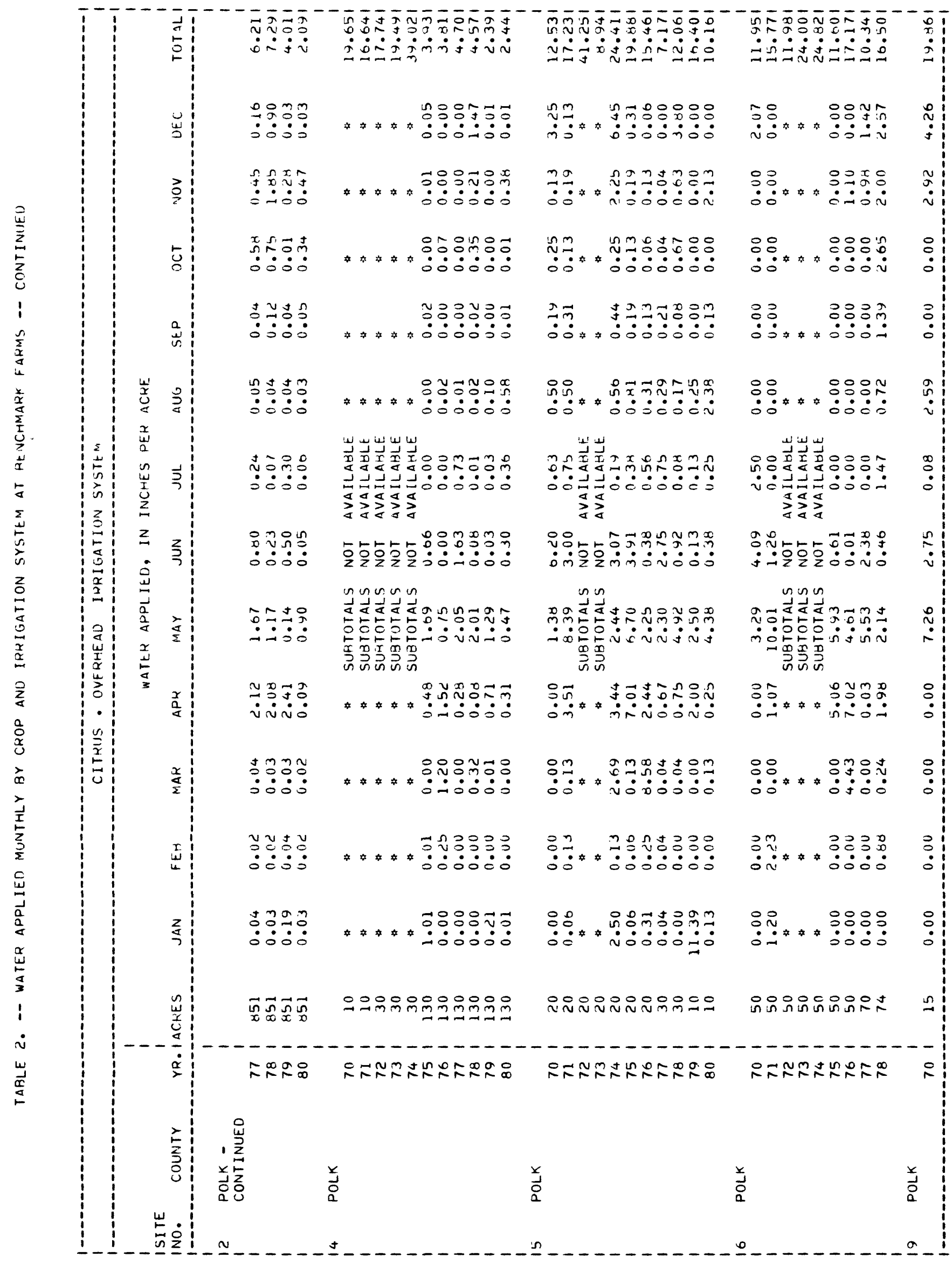




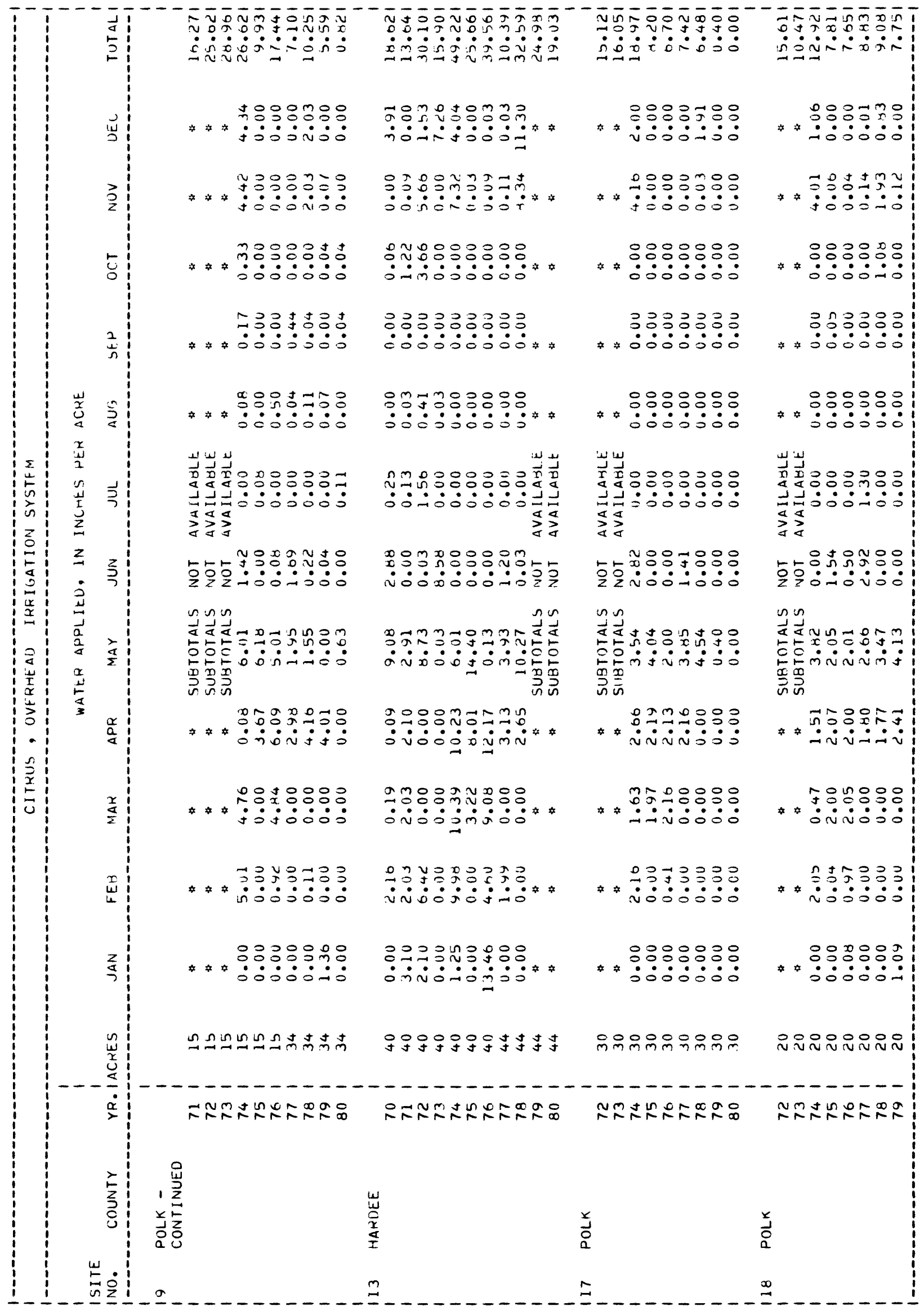




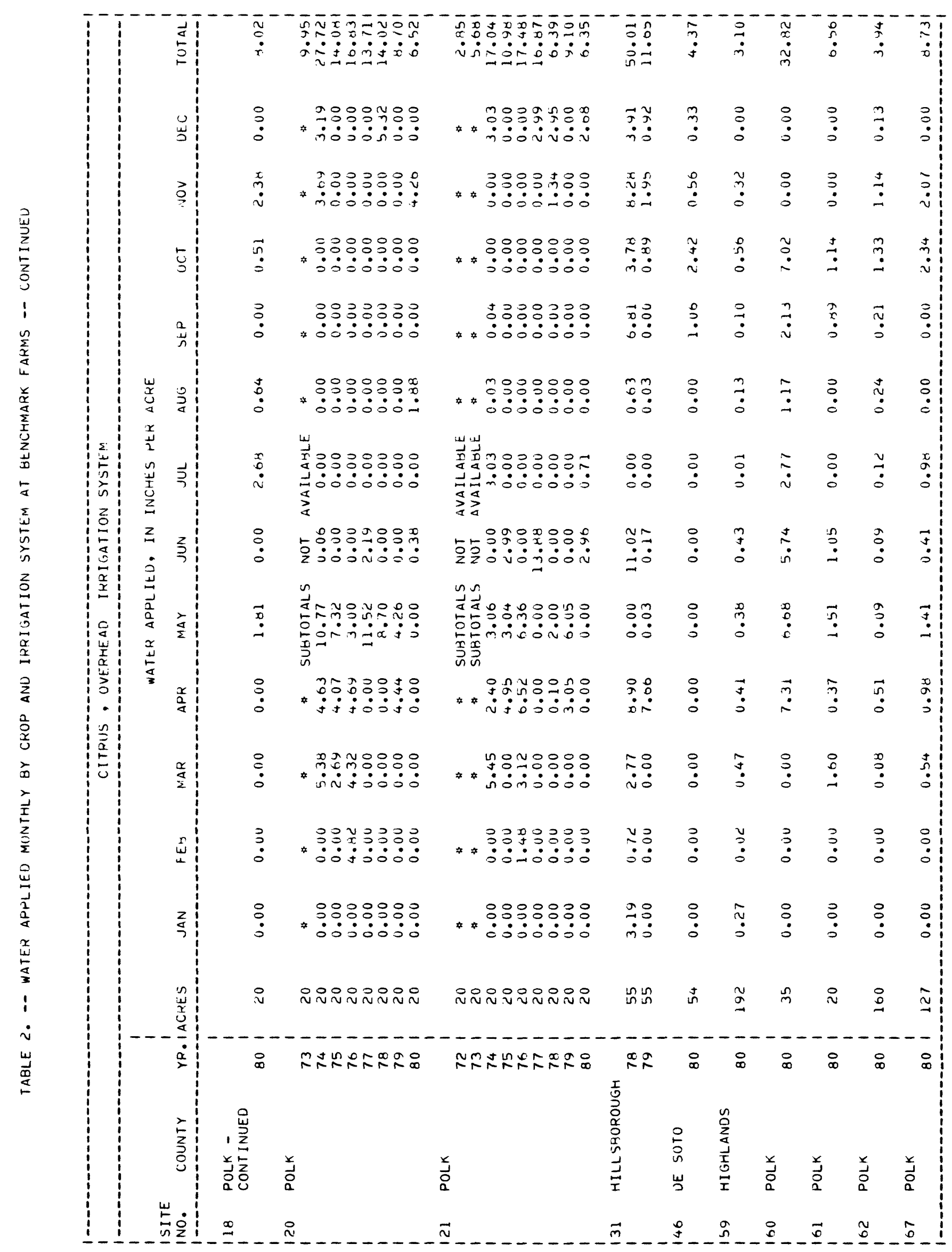



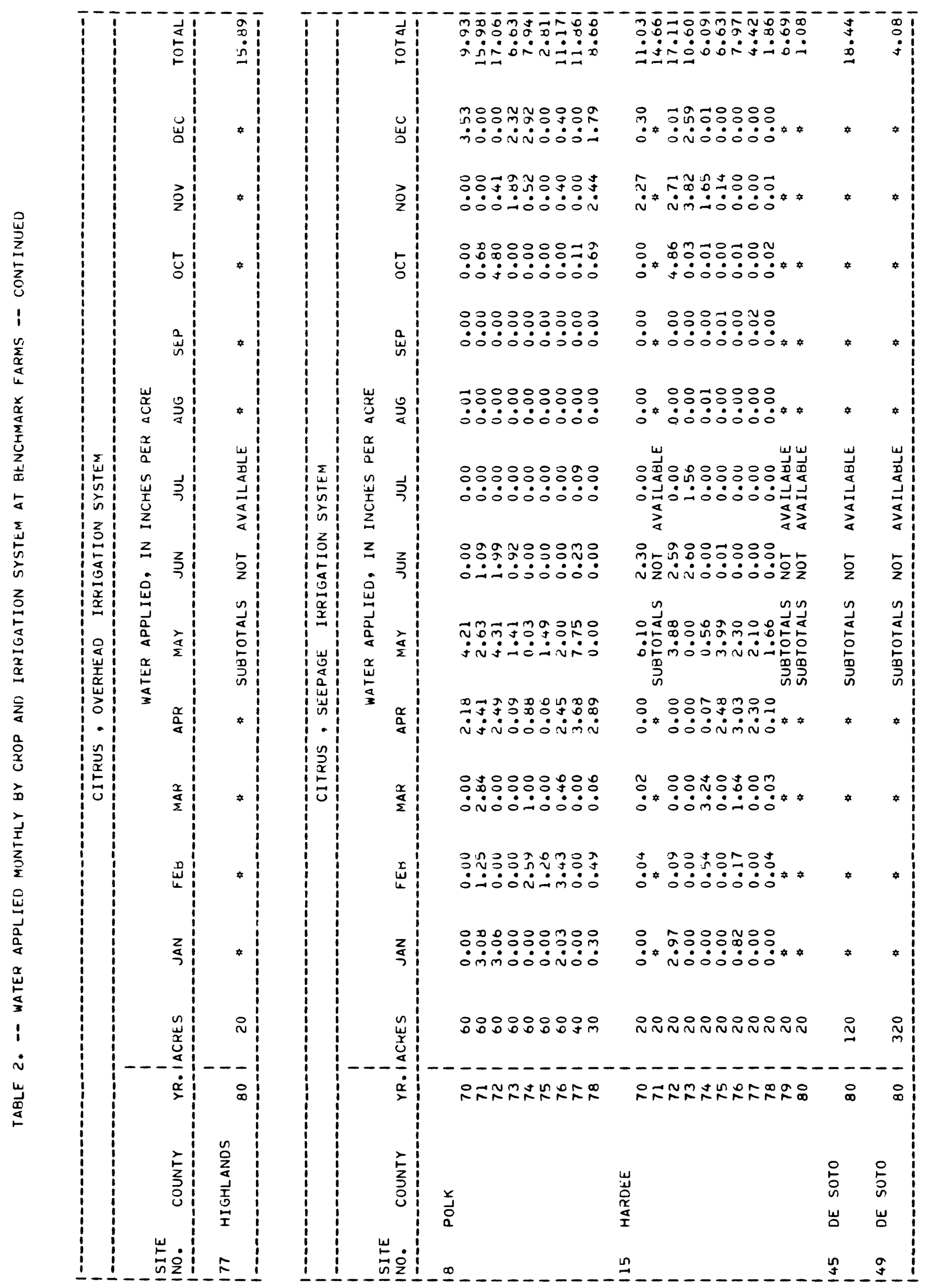


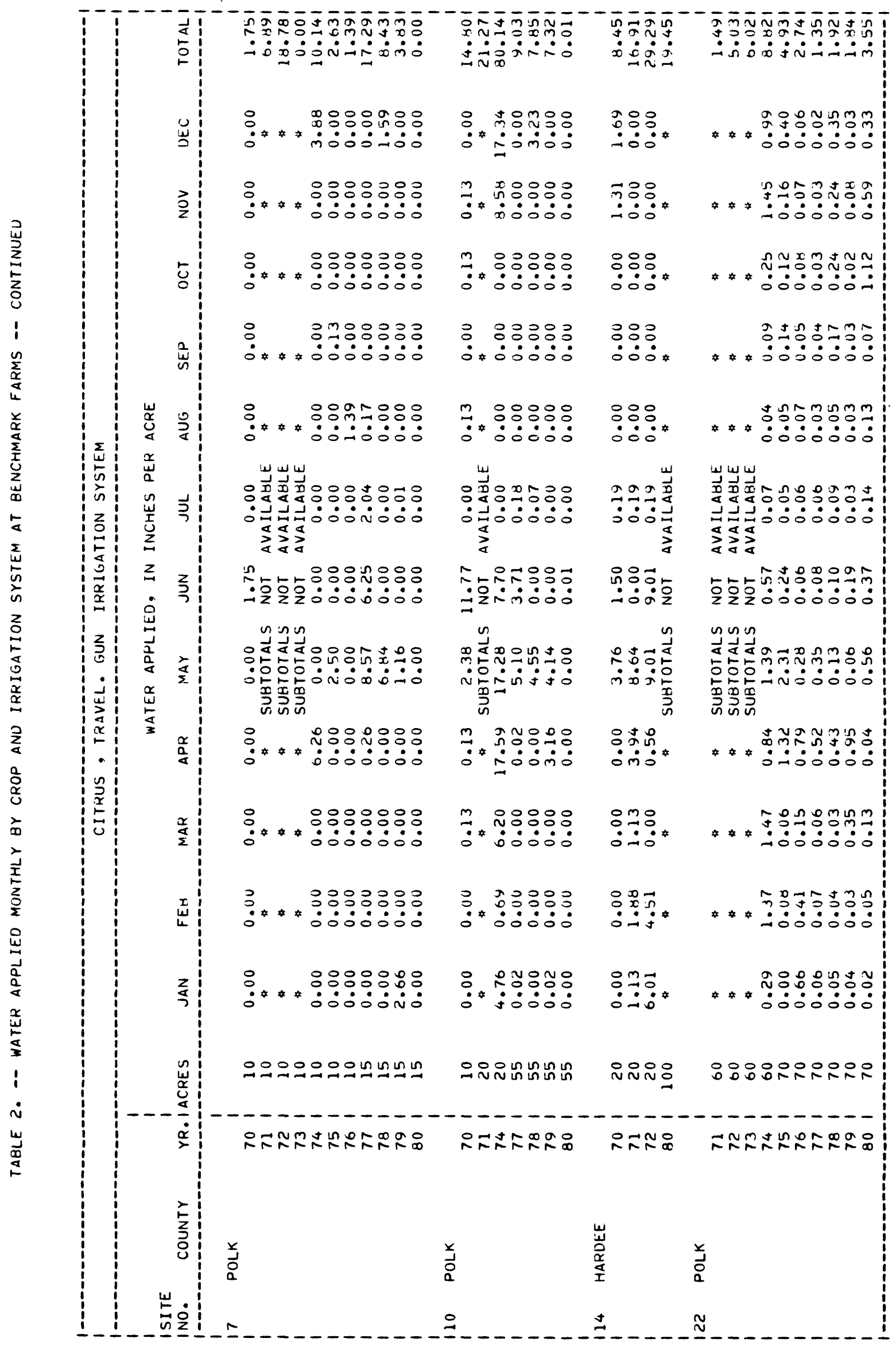




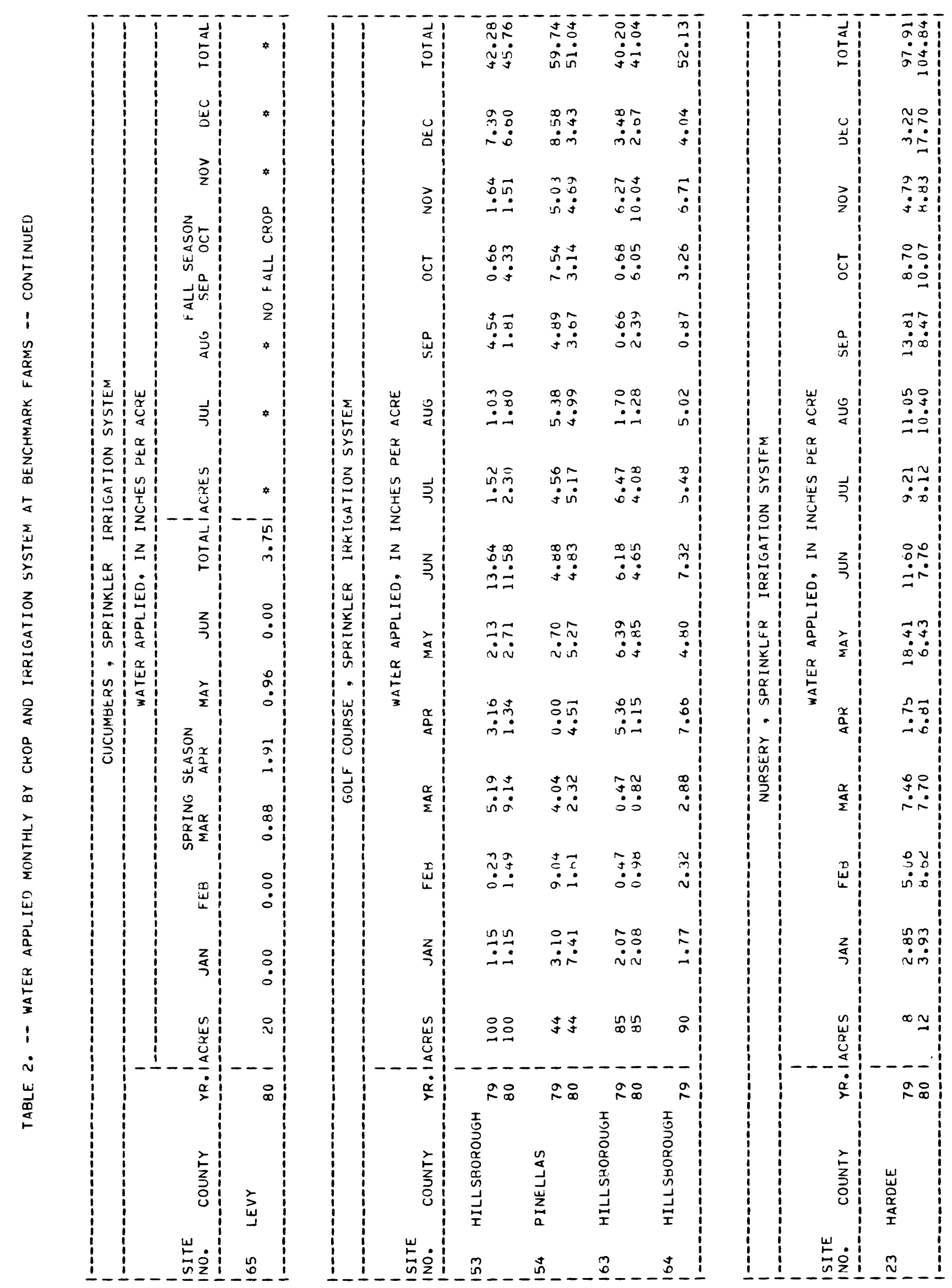




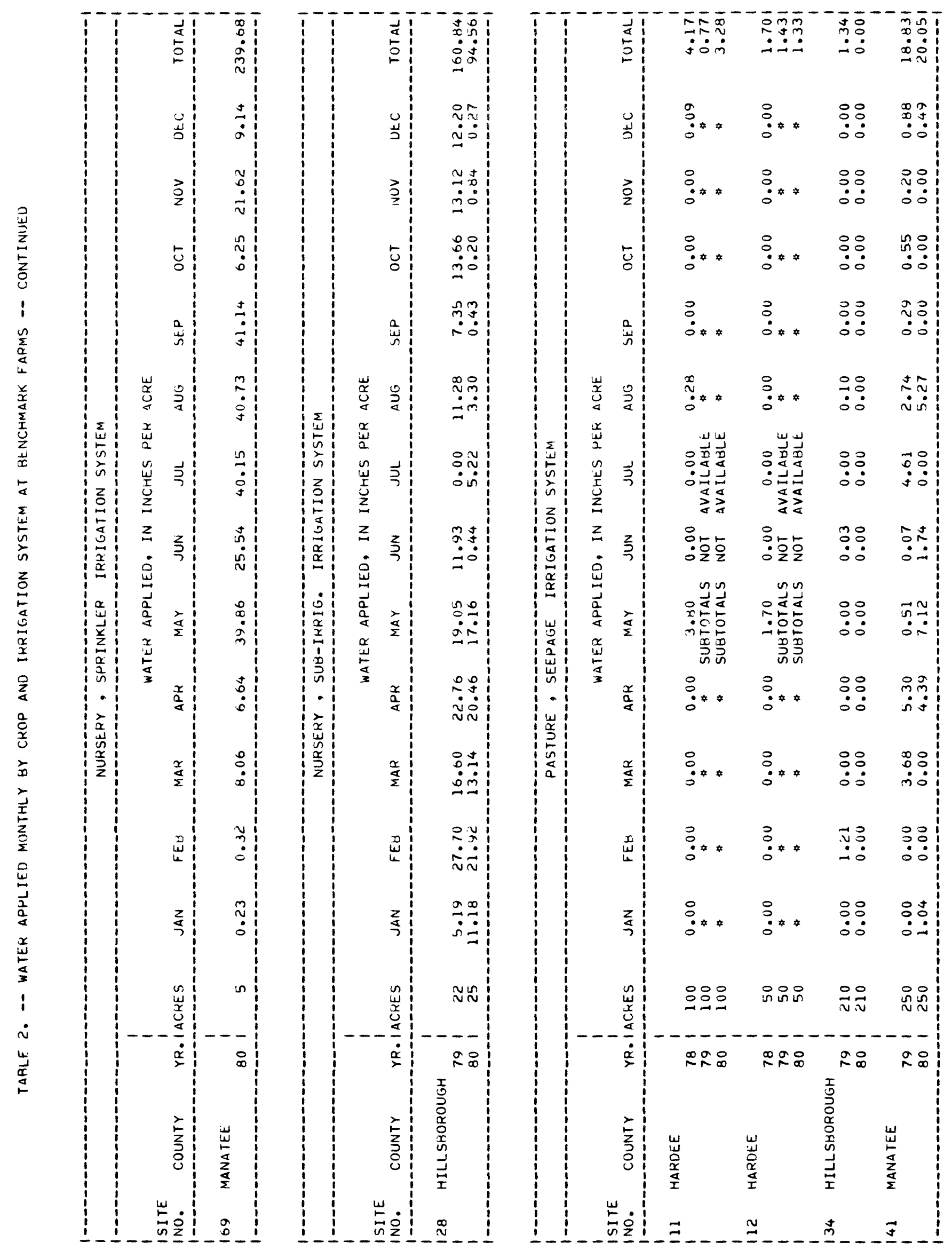




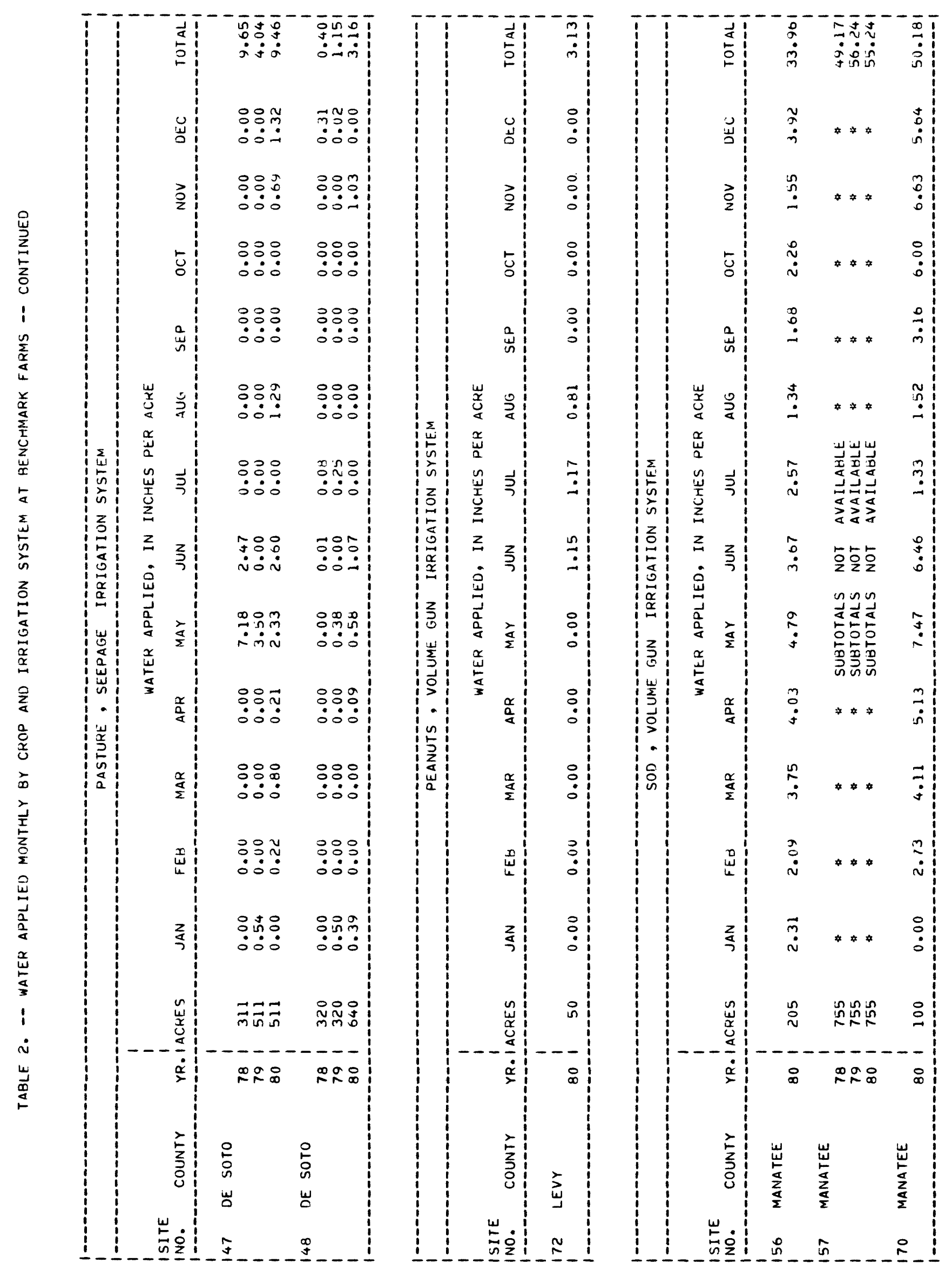



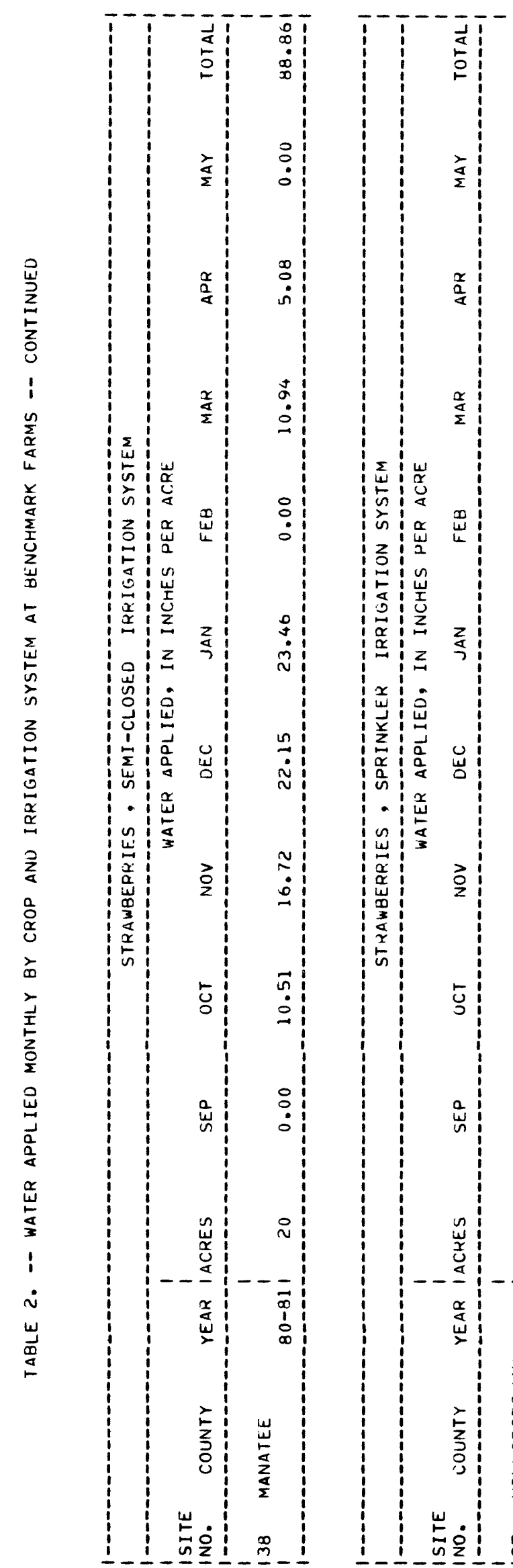

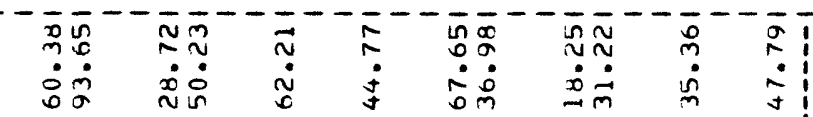

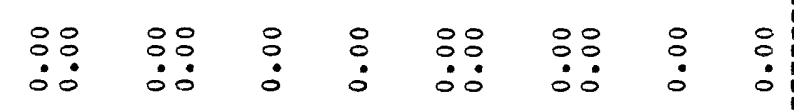

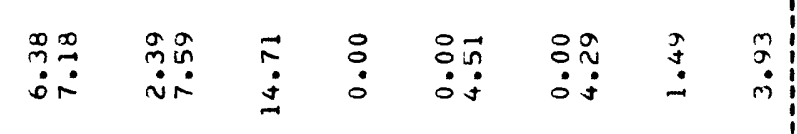

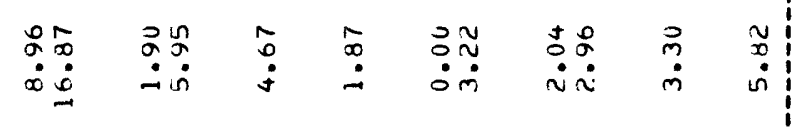

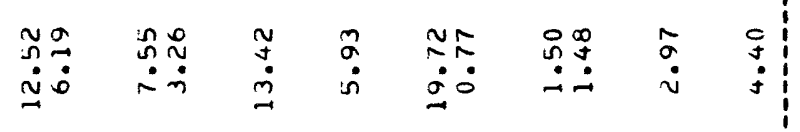

:

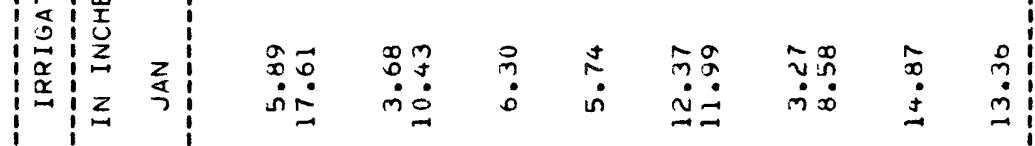

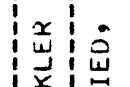

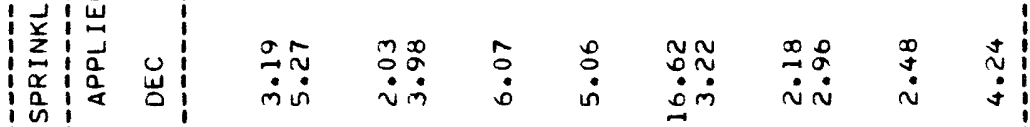
in

热

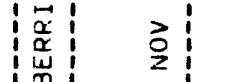

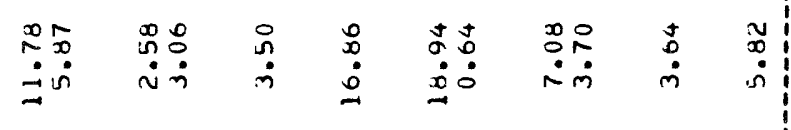

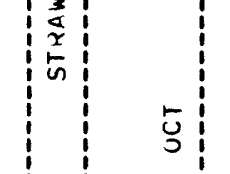

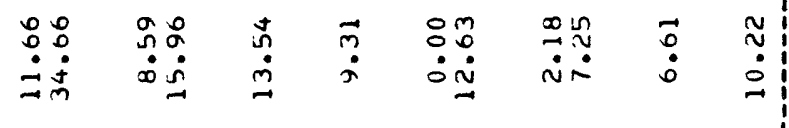

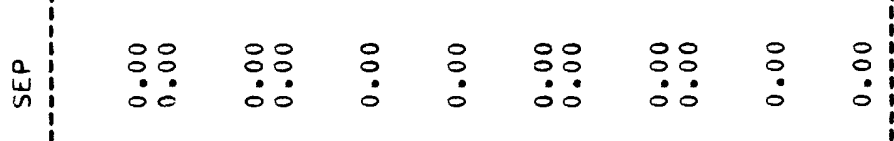

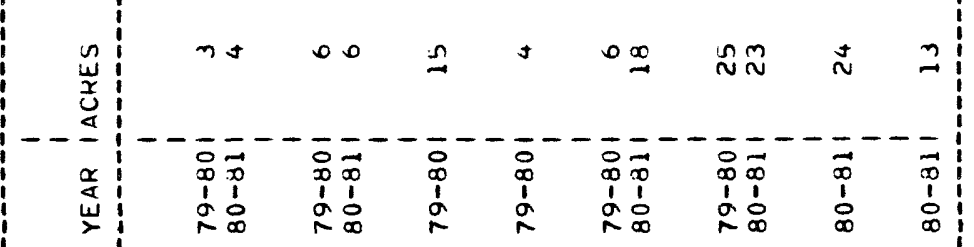

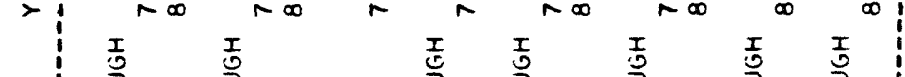

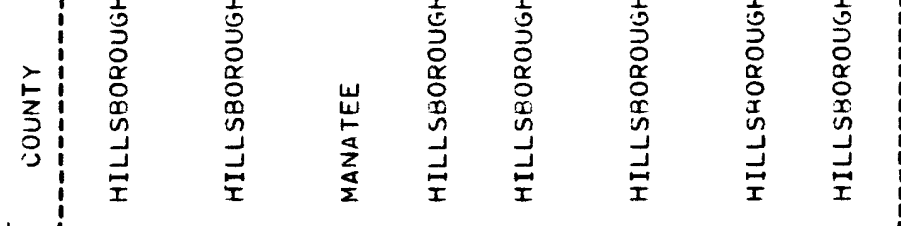

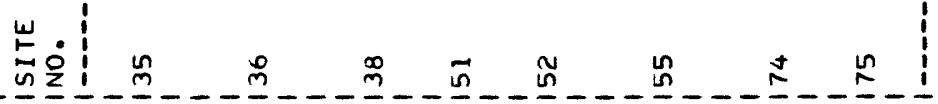




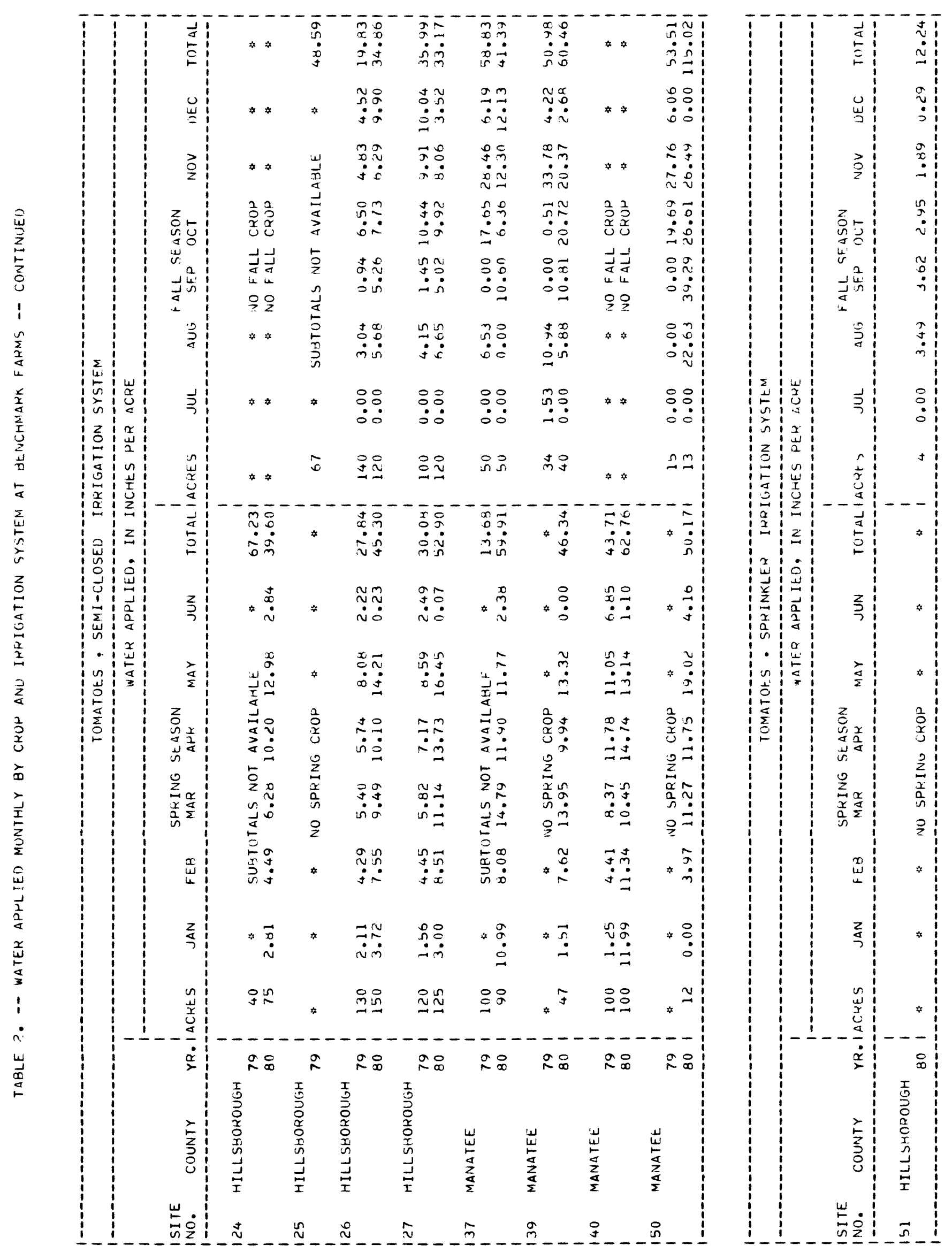



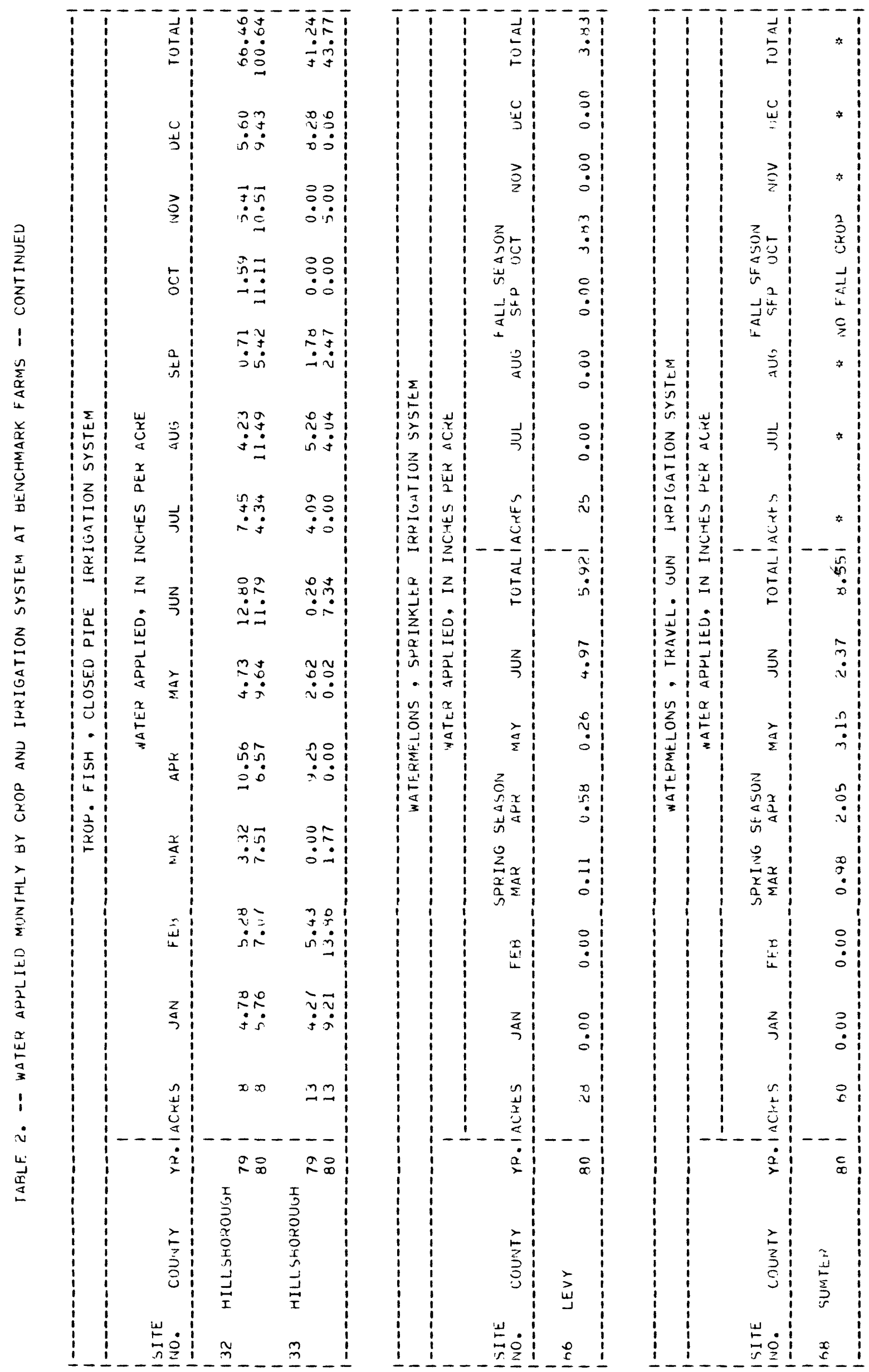

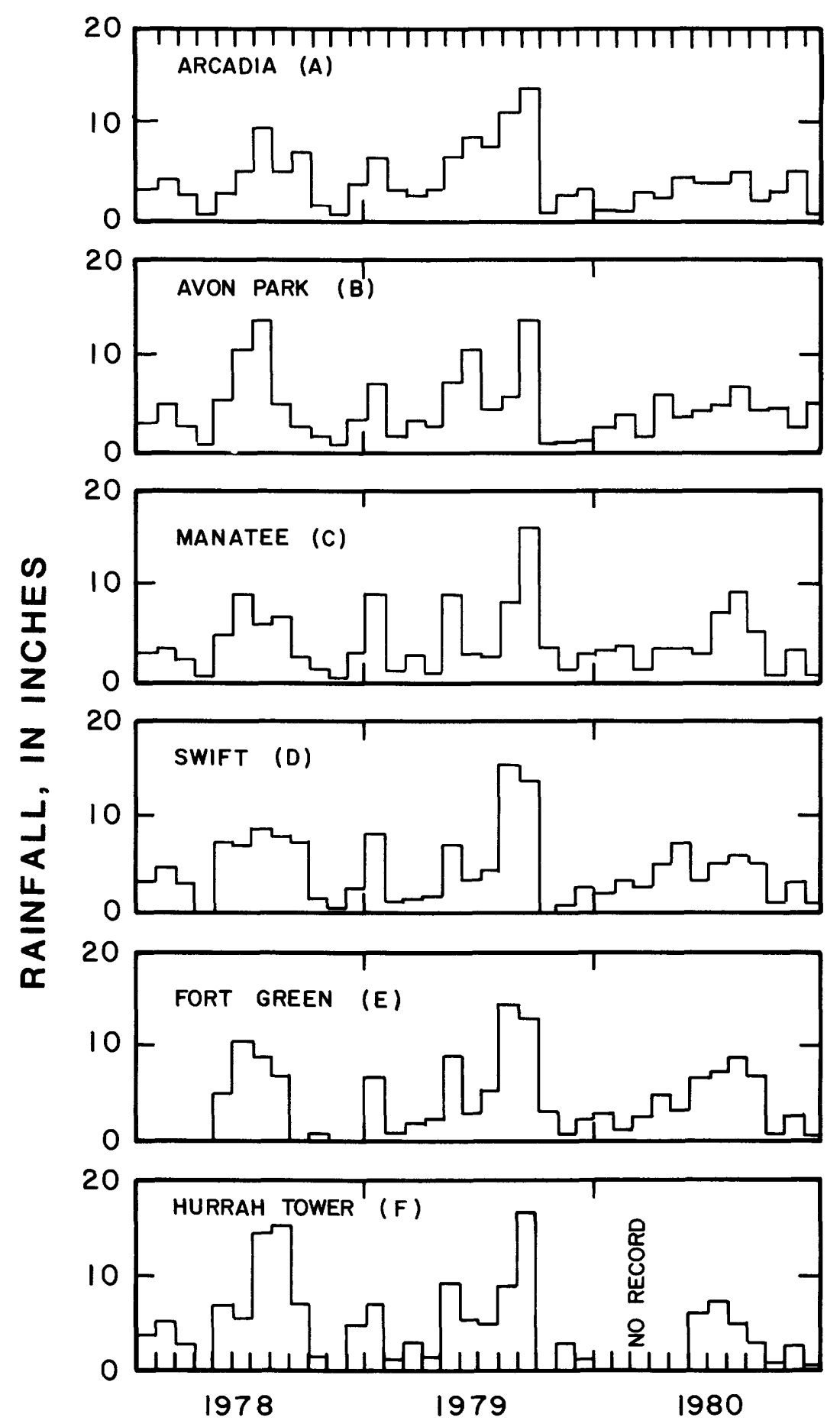

Figure 8.--Rainfall for stations in central and southern parts of the study area, 1978-80. 

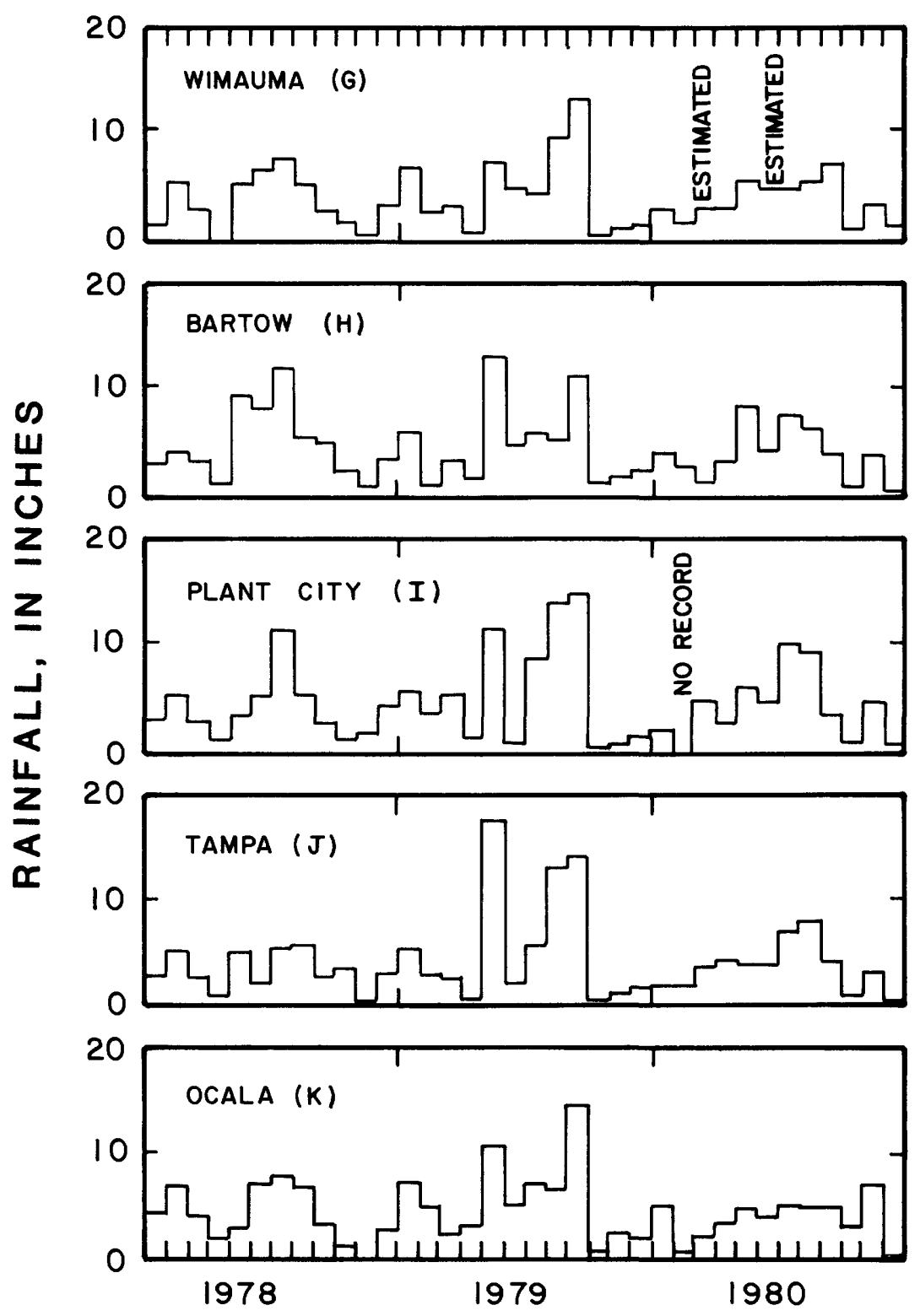

Figure 9.--Rainfall for stations in west-central and northern parts of the study area, 1978-80. 


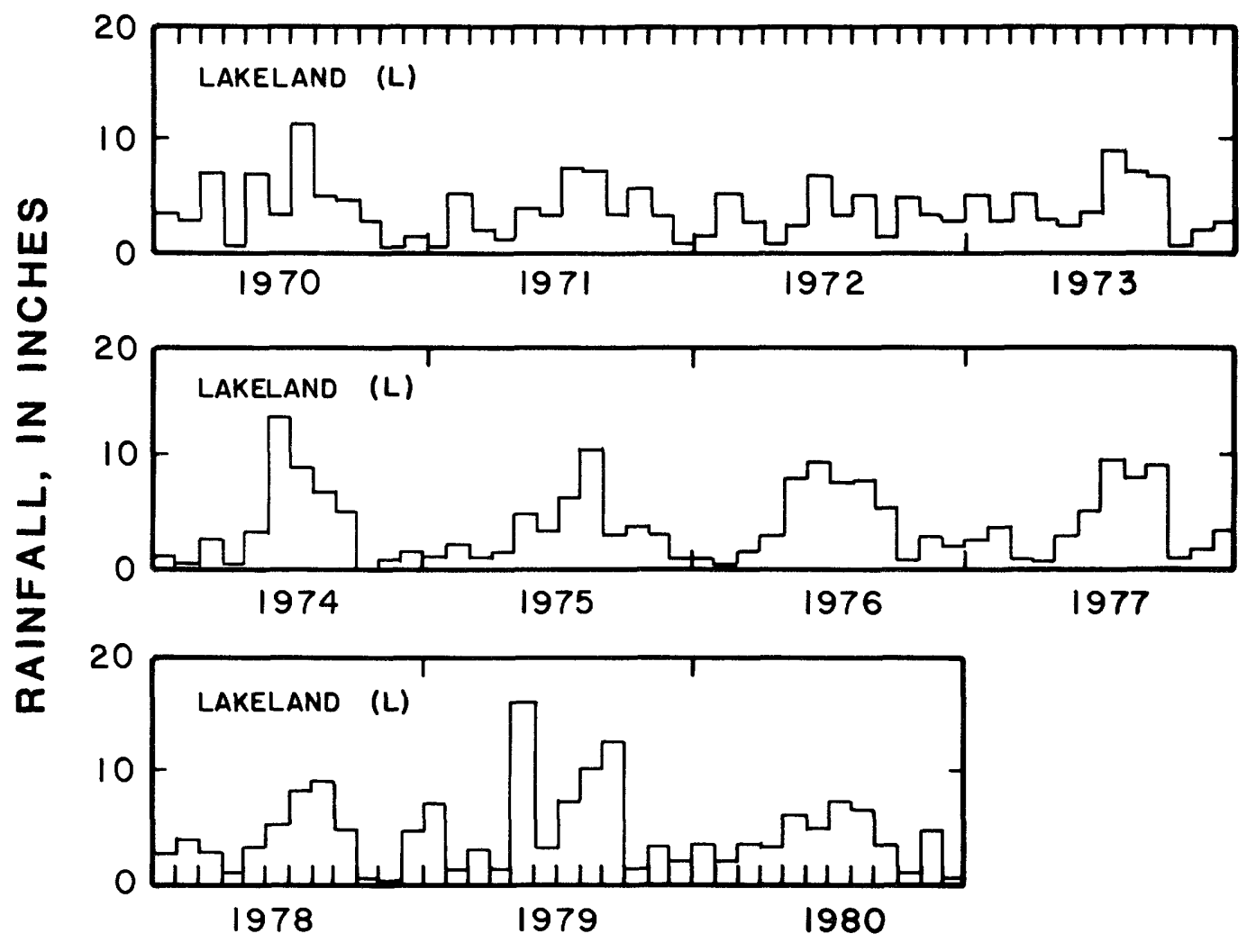

Figure 10.--Rainfall at Lakeland, 1970-80. 


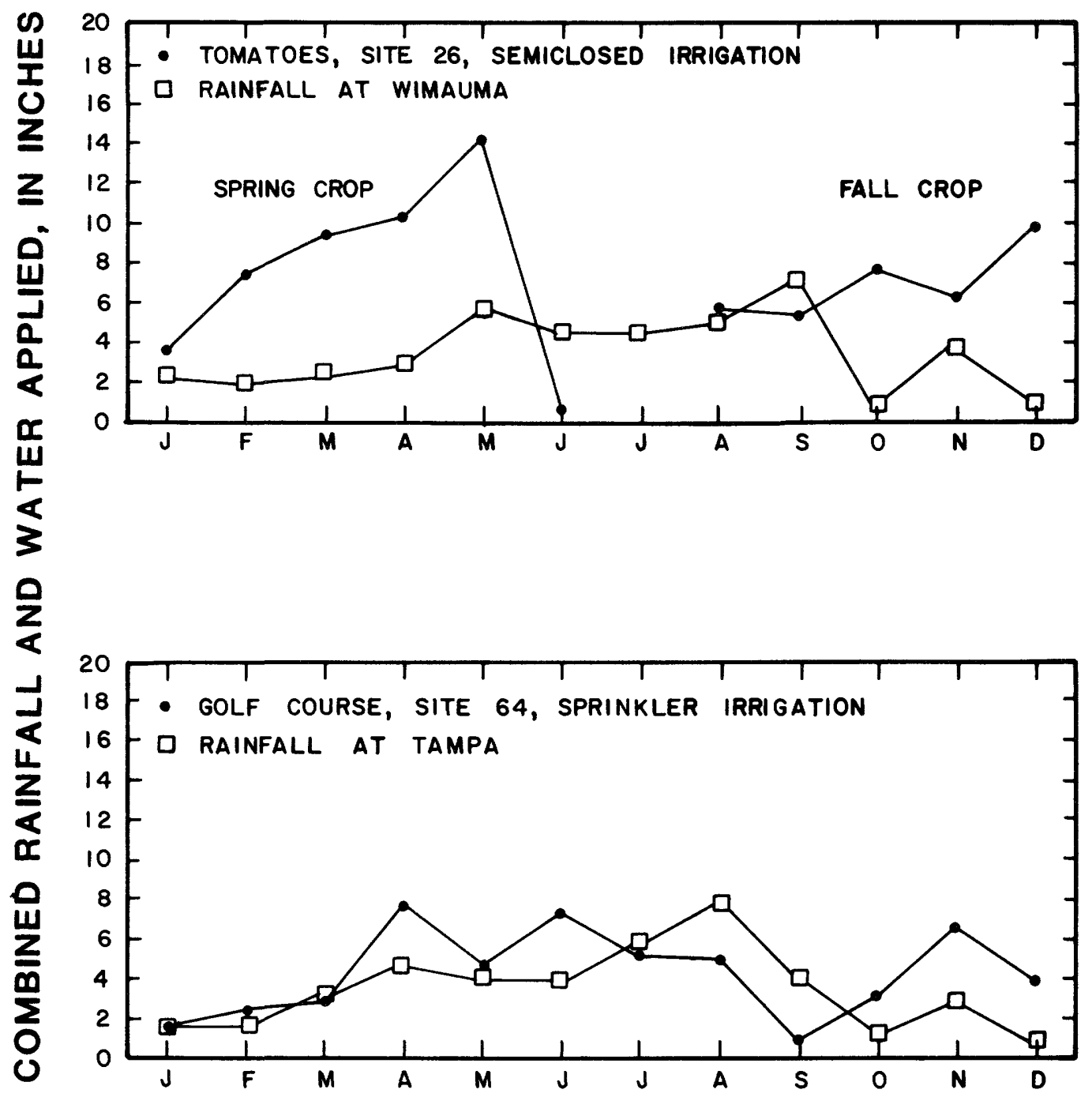

Figure 11.--Rainfall at Wimauma and Tampa and water applied at sites 26 and $64,1980$. 


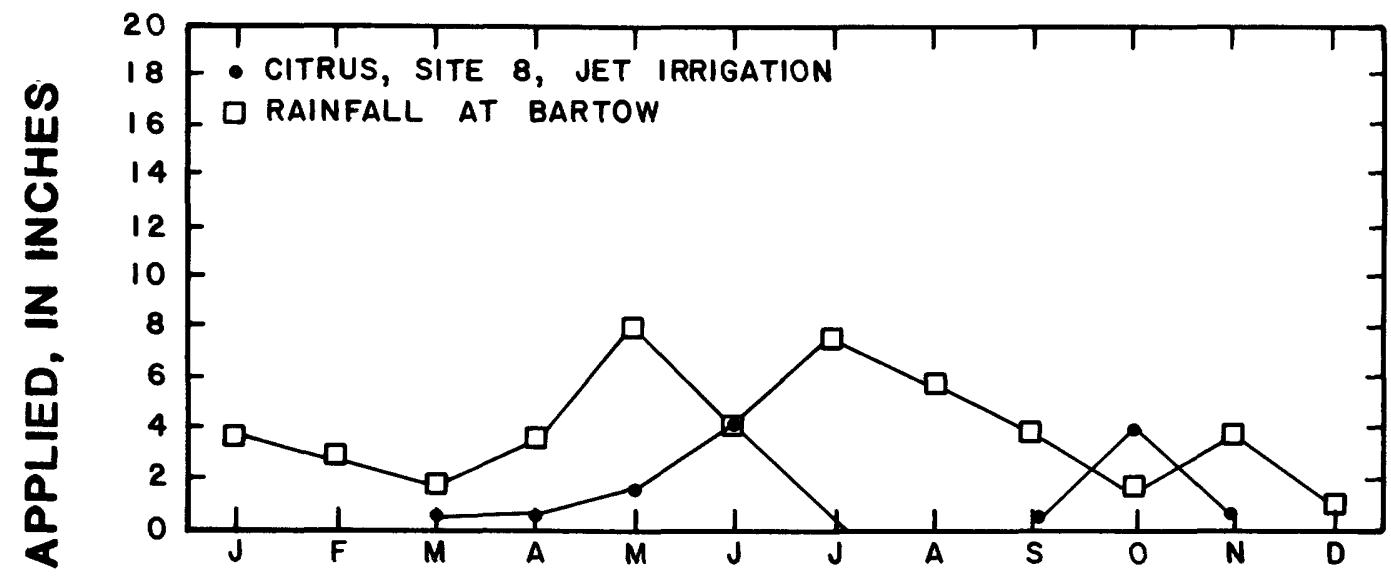

呆
$\frac{5}{5}$
3

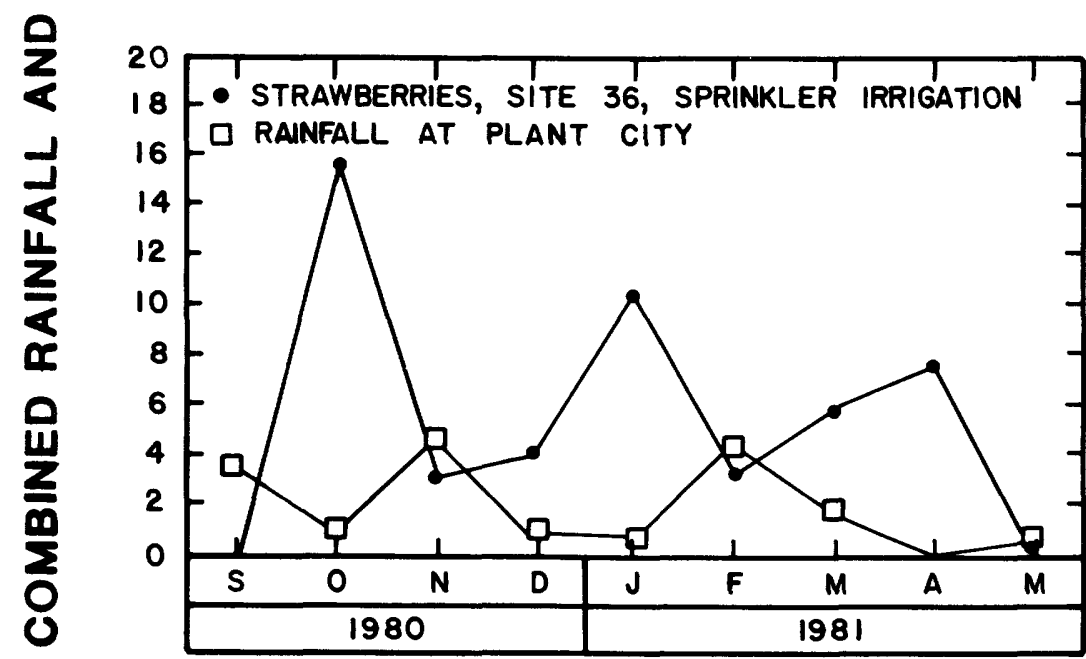

Figure 12.--Rainfall at Bartow and Plant City and water applied at sites 8 and 36, 1980-81. 


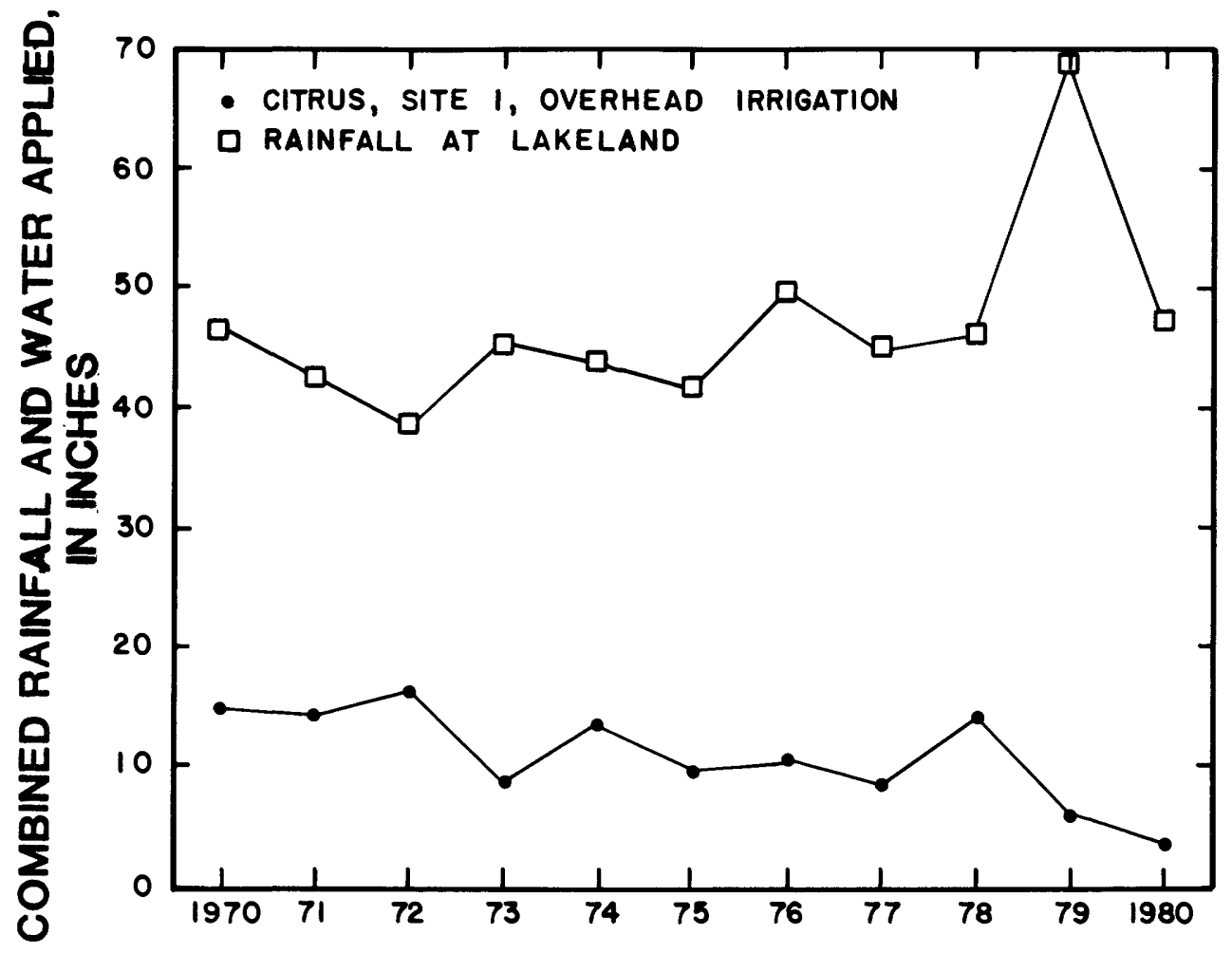

Figure 13.--Rainfall at Lakeland and water applied at site $1,1970-80$. 


\section{Citrus}

The 1980 composite mean annual water-application rate based on data for 35 citrus groves was 8.4 in/acre (table 3). Drip irrigation for 4 sites averaged $10.7 \mathrm{in} / a c r e$, jet irrigation for 7 sites averaged $10.2 \mathrm{in} / \mathrm{acre}$, overhead irrigation for 17 sites averaged 7.9 in/acre, seepage irrigation for 3 sites averaged $7.9 \mathrm{in} / \mathrm{acre}$, and traveling gun irrigation for 4 sites averaged $5.8 \mathrm{in} / \mathrm{acre}$. The largest water use for citrus irrigation during 1980 occurred at site 60 in Polk County (table 2). The annual application rate was 32.8 in/acre using an overhead irrigation system. This site also had the largest monthly application rate in $1980,7.3$ in/acre in April. Water was not applied for citrus irrigation in 1980 at sites 7 and 17 in Polk County.

\section{Cucumbers}

One cucumber farm in Levy County was monitored during 1980 for water use. A spring crop irrigated by sprinkler used 3.8 in/acre. All water was applied during March, April, and May.

\section{Golf Courses}

Three golf courses using sprinkler irrigation were monitored during 1980 . The low, mean, and high application rates were $41.0,45.9$, and $51.0 \mathrm{in} / \mathrm{acre}$, respectively. Monthly rates ranged from $0.8 \mathrm{in} / \mathrm{acre}$ in March at site 63 to $11.6 \mathrm{in} / \mathrm{acre}$ in June at site 53. Irrigated acreage averaged 4.2 per hole and ranged from 2.4 acres at site 54 to 5.6 acres at site 53 .

\section{Nurseries}

For three nursery sites, the composite mean annual water-application rate during 1980 was 146.4 in/acre. Monthly rates ranged from 0.2 in/acre in October at site 28 to 41.1 in/acre in September at site 69 . For the two sites with sprinkler irrigation systems, the mean annual application rates were 104.8 and 239.7 in/acre. The nursery site with a subirrigation system applied 94.6 in/acre.

\section{$\underline{\text { Pasture }}$}

The mean annual water-application rate during 1980 for six pasture sites with seepage irrigation systems was $6.2 \mathrm{in} /$ acre, including no irrigation for site 34. The sites grew various types of grasses and individual annual application rates ranged from no irrigation for grazing grass to $9.5 \mathrm{in} /$ acre for rye grass and to $20.0 \mathrm{in} / \mathrm{acre}$ for clover. 


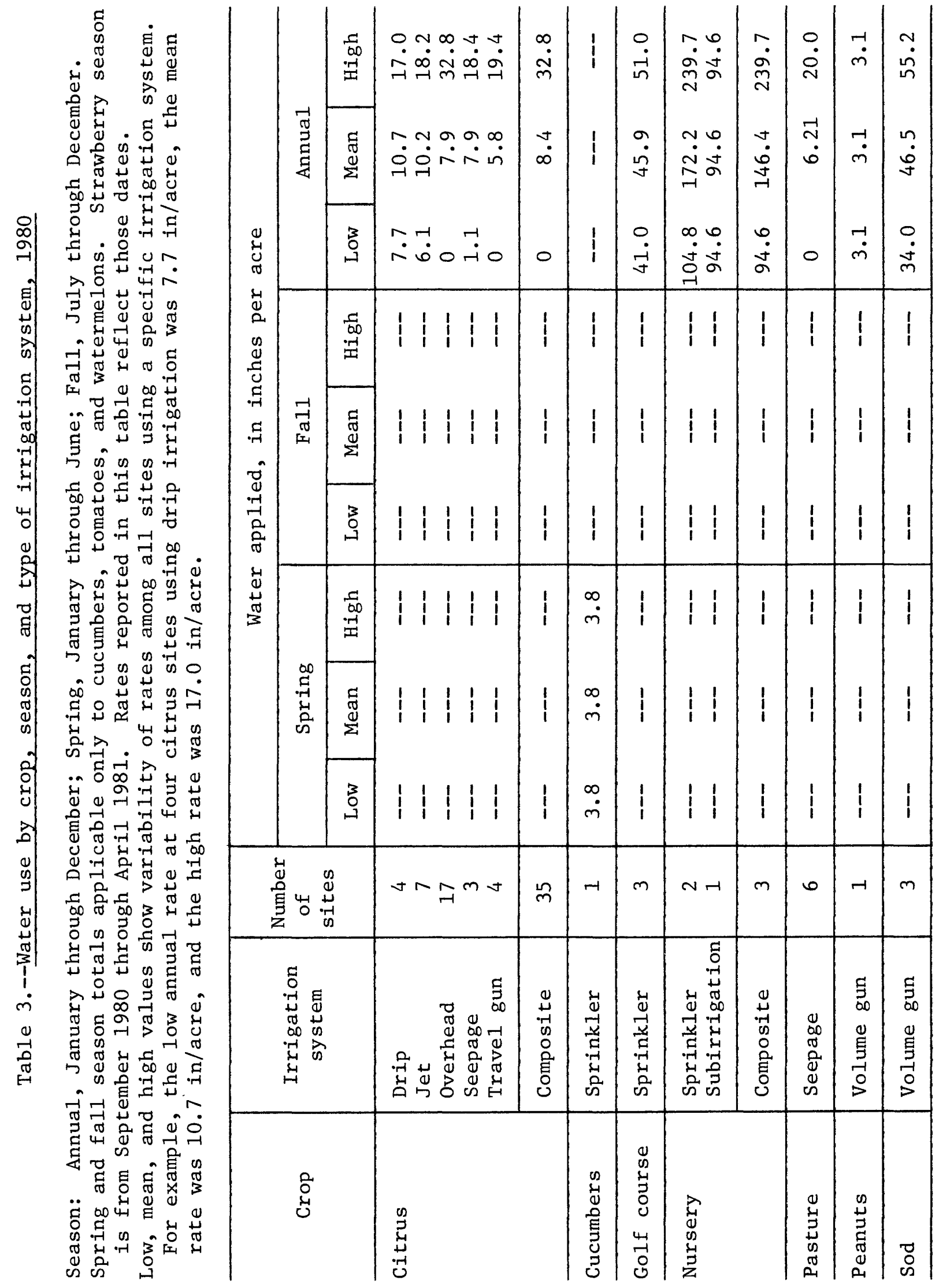




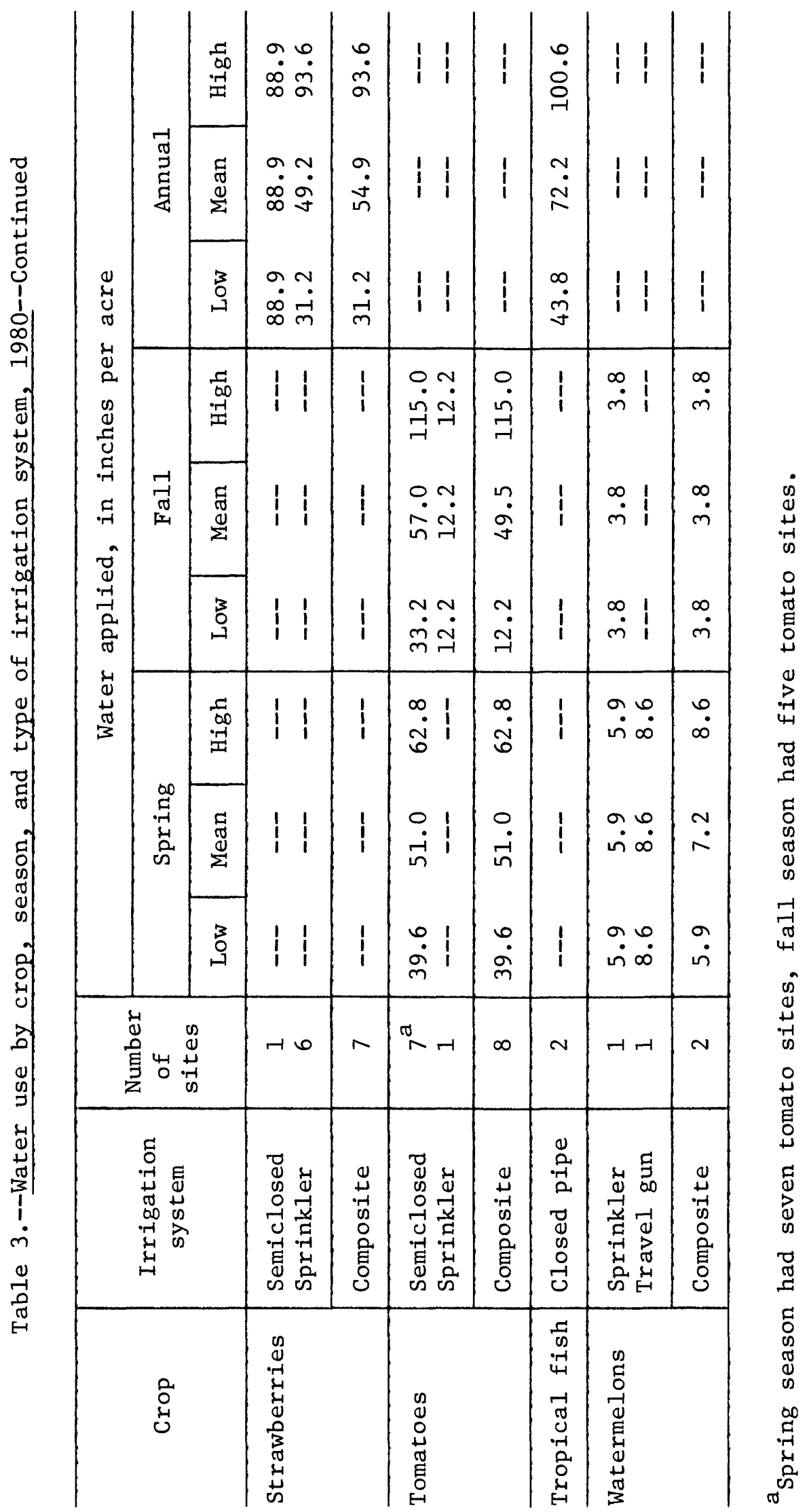


One peanut farm in Levy County was monitored during 1980. An annual crop irrigated with a volume gun system used 3.1 in/acre. A1l water was applied during June, July, and August.

$\underline{\text { Sod }}$

The mean annual water-application rate during 1980 for three sod farms with volume gun irrigation was $46.5 \mathrm{in} / \mathrm{acre}$. The low and high rates were 34.0 and $55.2 \mathrm{in} /$ acre, respectively. Monthly rates ranged from no irrigation in January to 7.5 in/acre in May at site 70 . Monthly subtotals were not available at site 57 .

Sod grown at these sites were certified weed-free St. Augustine grasses. This grass type uses considerably more water than Bahia grasses. Water-application rates for Bahia grass are probably similar to rates applied to pastures.

\section{Strawberries}

Strawberries are planted in the fall of one year and harvested in the spring of the following year. The seasons are divided into fall and spring in table 1 and monthly rates are shown in table 2. Data presented in table 3 and discussed in this section are for October 1980 through April 1981.

The composite mean annual water-application rate for seven strawberry farms was $54.9 \mathrm{in} / \mathrm{acre}$. The low, mean, and high rates for six sites with sprinkler irrigation systems were $31.2,49.2$, and $93.6 \mathrm{in} / \mathrm{acre}$, respectively. The farm with a semiclosed irrigation system applied 88.9 in/acre. Semiclosed irrigation systems are not common for strawberry farms. Although they are less likely to spread disease than sprinkler irrigation systems, they have the disadvantage of using more water per acre and being less effective for frost protection.

Monthly rates for the six sprinkler irrigation sites ranged from 0.6 in/acre in November at site 52 to $34.7 \mathrm{in} /$ acre in October at site 35 . Of the water applied at site 35, water pumped for frost and freeze protection during December, January, and February was $1.5 \mathrm{in} / \mathrm{acre}, 17.6 \mathrm{in} / \mathrm{acre}$, and $2.3 \mathrm{in} / \mathrm{acre}$, respectively. Total water-application rates for the three months were 5.3 in/acre, $17.6 \mathrm{in} / \mathrm{acre}$, and $6.2 \mathrm{in} /$ acre (table 2).

\section{Tomatoes}

The low, mean, and high spring season water-application rates during 1980 for seven tomato farms with semiclosed irrigation systems were $39.6,51.0$, and $62.8 \mathrm{in} / \mathrm{acre}$, respectively. Monthly rates ranged from no irrigation in June at site 39 and in January at site 50 to 19.0 in/acre in May at site 50. 
The composite mean fall season water-application rate for six tomato farms was 49.5 in/acre. The low, mean, and high fall rates for five tomato farms with scmiclosed irrigation were $33.2,57.0$, and $115.0 \mathrm{in} / \mathrm{acre}$, respectively. The unusually high rate, $115.0 \mathrm{in} / \mathrm{acre}$ at site 50 , was attributed to its location on a wel1-drained sand ridge. Monitoring of this site continued because its spring crop was located on more favorable topography. Monthly rates for the five farms with semiclosed irrigation ranged from no irrigation during several months at all sites to $39.3 \mathrm{in} /$ acre in September at site 50 . The farm with sprinkler irrigation applied 12.2 in/acre during the fall season.

\section{Tropical Fish}

The low, mean, and high annual water-application rates during 1980 for two tropical fish farms with closed-pipe irrigation systems were 43.8, 72.2, and $100.6 \mathrm{in} / a c r e$, respectively. Monthly rates ranged from no irrigation in April, July, and October at site 33 to 13.9 in/acre in February, also at site 33 . All water used by the fish farms was ground water. The water was used to maintain constant pond levels and to minimize temperature variations in summer and winter.

Watermelons

The spring water-application rate for watermelons during 1980 was 5.9 in/acre for a site with a sprinkler irrigation system and $8.6 \mathrm{in} / \mathrm{acre}$ for a site with a trave1-gun irrigation system. Water was applied from March through June at both sites. The largest monthly rate was 5.0 in/acre in June at site 66 (sprinkler irrigation). This site also had a fall crop, which applied 3.8 in/acre in October. Both watermelon sites were in Levy County. Higher waterapplication rates probably existed in the central and southern parts of the study area.

ESTIMATING TOTAL IRRIGATION WATER USE

Data from the benchmark farm program serve as a basis for estimating the 1980 water-application rates applied throughout the entire study area. Mean water-application rates given for each crop (table 3) may be misleading when extremely high or low application rates caused by unusual conditions occurred at one or two sites. Rates were adjusted from those shown in table 3 where unusual pumpage was believed to have occurred. Adjustments were made considering factors such as rainfall, soil type, economic conditions, data obtained from County Extension Services, and consumptive water-use permits issued by the Southwest Florida Water Management District. For example, in 1980, water applied at fish farm sites 32 and 33 totaled 100.6 and $43.8 \mathrm{in} / a c r e$, respectively (table 2), for a mean rate of 72.2 in/acre (table 3). Site 32 was underlain by well-drained, sandy soil and required more water to maintain pond levels than site 33. Therefore, the unusually high rate at site 32 was disregarded and the 1980 water-application rate for fish farms was adjusted to $40 \mathrm{in} /$ acre in accordance with the rate for site 33 and the rates permitted by the Southwest Florida Water Management District. 
Adjusted 1980 application rates are presented in figure 14. Adjusted monthly rates are presented in table 4. The rates shown are generalized and vary from area to area and crop to crop. The adjusted rates for each area (county or drainage basin) are applied to estimated irrigated acres for each crop to estimate total irrigation water applied (Duerr and Trommer, 1981b). Estimates of irrigated acreage are obtained from the U.S. Soil Conservation Service, County Extension Services, Southwest Florida Water Management District, Florida Crop and Livestock Reporting Service, and field observations.

The mean water-application rate for four benchmark tomato farms in Manatee County during the spring of 1980 was calculated as 54.8 in/acre. Applying an adjusted rate of 50 in/acre (table 4) to the estimated 5,500 irrigated acres of tomatoes in the county, a total of 22,900 acre-ft $(20.4 \mathrm{Mgal} / \mathrm{d})$ of water was used for tomato irrigation in Manatee County in the spring of 1980. Similar calculations are made for each crop in each county.

SUMMARY

Irrigation water-use data are summarized for 74 benchmark farms in southwest Florida. Monthly water-application rates are given for 11 different crops. Data for 18 citrus farms go back to the early 1970's. In 1980, water-application rates ranged from no irrigation for several citrus and pasture sites to 239.7 in/acre for a nursery.

The water-application rates determined from the benchmark farm data are used as a guide for estimating total 1980 irrigation water use in the Southwest Florida Water Management District. Total irrigation data are shown in a separate report by Duerr and Trommer (1981b). 


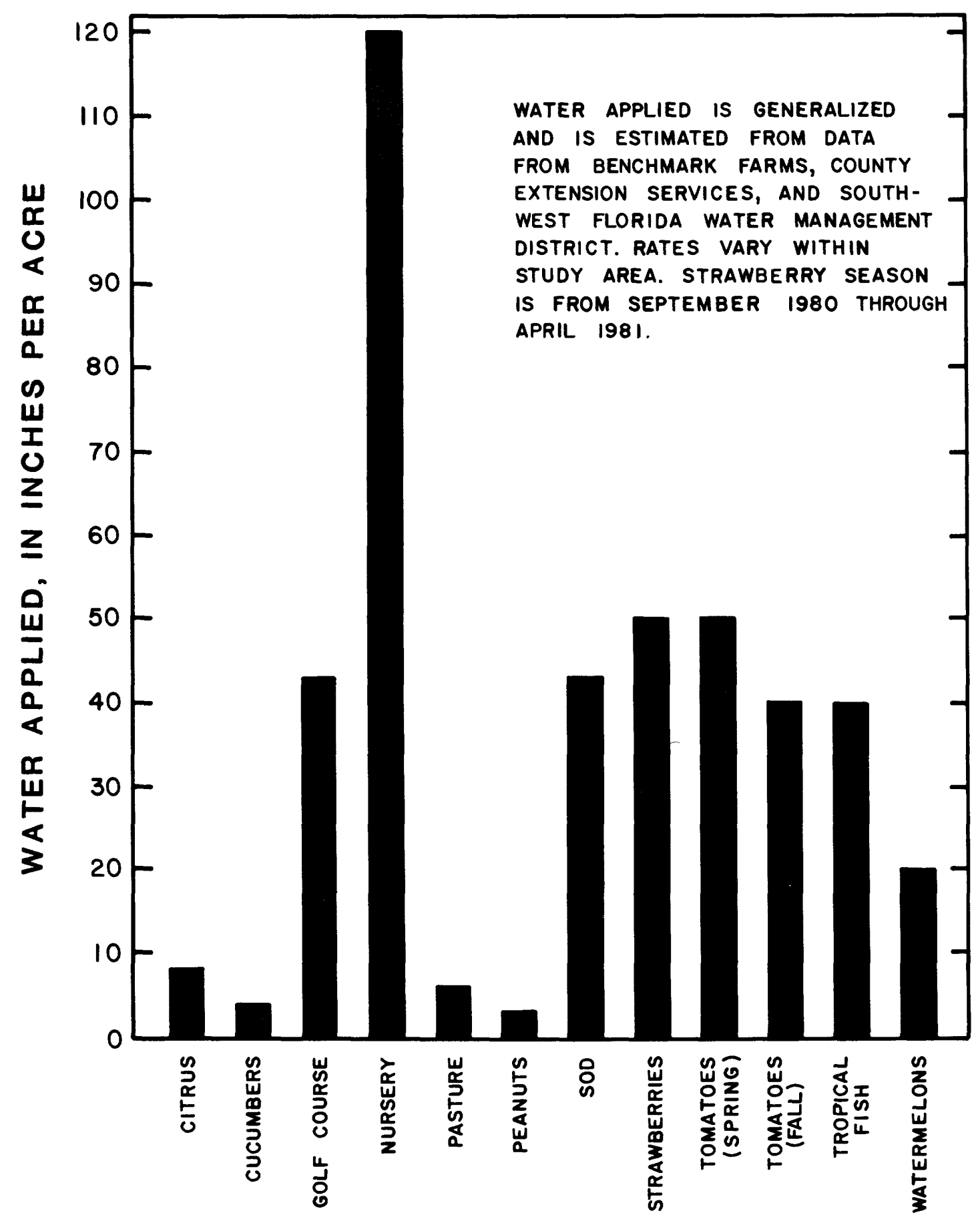

Figure 14.--Adjusted water-application rates by crop, 1980. 
Table 4.--Crop calendar and adjusted monthly water-application rates by crop, 1980

FIELD

PREPARATION

CITRUS IS AN ANNUAL CROP WITH HARVEST TIME DEPENDING ON CROP VARIETY. CITRUS APPLICATION RATES REPRESENT AN GROWTH PERIOD AVERAGE OF ALL VARIETIES. STRAWBERRY SEASON IS FROM SEPTEMBER 1980 THROUGH APRIL 1981.

HARVEST

WATER APPLIED IS GENERALIZED AND IS ESTIMATED FROM DATA FROM BENCHMARK FARMS, COUNTY EXTENSION SERVICES, AND SOUTHWEST FLORIDA WATER MANAGEMENT DISTRICT

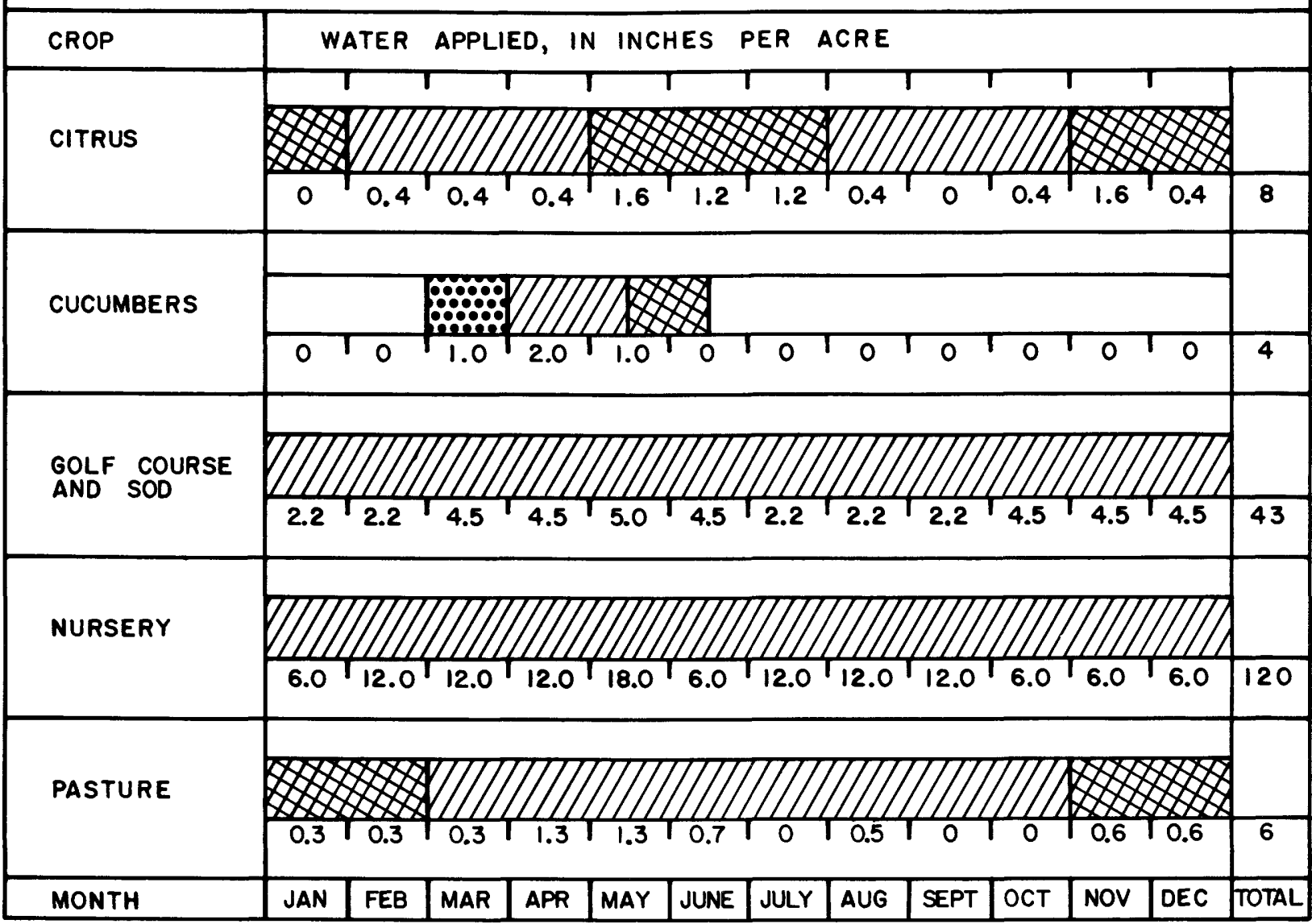


Table 4.--Crop calendar and adjusted monthly water-application rates by crop, 1980--Continued

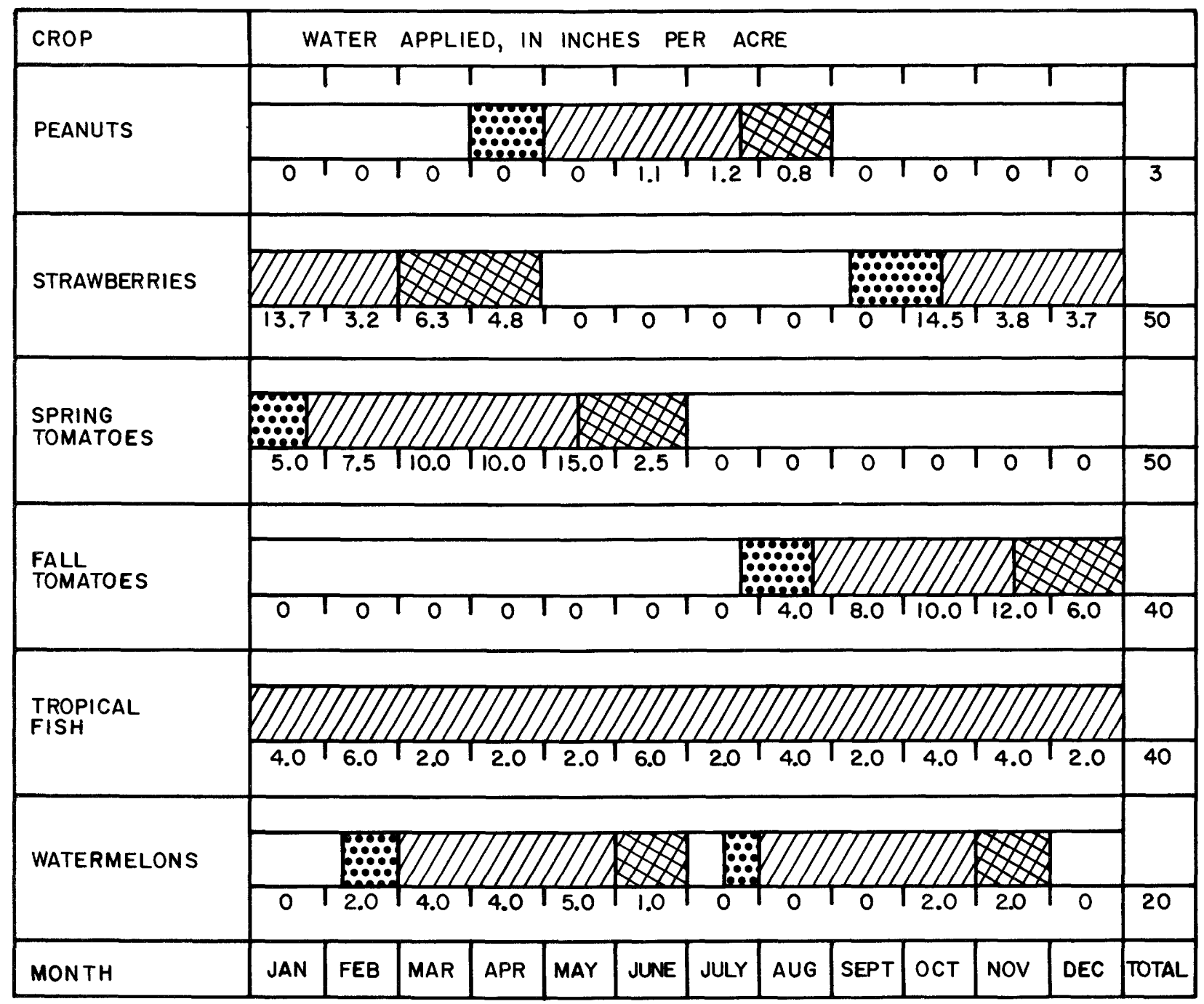


Anderson, K. E., 1973, Water well handbook: Missouri Water Well and Pump Contractors Association.

Duerr, A. D., and Trommer, J. T., 1981a, Estimated water use in the Southwest Florida Water Management District and adjacent areas, 1979: U.S. Geological Survey Open-File Report 81-56, 58 p.

$1981 \mathrm{~b}$, Estimated water use in the Southwest Florida Water Management District and adjacent areas, 1980: U.S. Geological Survey Open-File Report $81-1060,60 \mathrm{p}$.

Leach, S. D., 1978, Source, use, and disposition of water in Florida, 1975:

U.S. Geological Survey Water-Resources Investigations 78-17, 90 p.

Leach, S. D., and Healy, H. G., 1980, Estimated water use in Florida, 1977:

U.S. Geologica1 Survey Water-Resources Investigations 79-112, 76 p.

Pride, R. W., 1973, Estimated use of water in Florida, 1970: Florida Bureau of Geology Information Circular 83, 31 p.

Robertson, A. F., and Mills, L. R., 1974, Ground-water withdrawals in the upper Peace and upper Alafia River basins, Florida: Florida Bureau of Geology Map Series 67.

Robertson, A. F., Mills, L. R., and Parsons, D. C., 1978, Ground-water withdrawn for municipal, industrial, and irrigation use in the upper Peace and Alafia River basins, west-central Florida, 1970-74: U.S. Geological Survey OpenFile Report 78-29, 59 p.

Suwannee River Water Management District, 1979, Procedure for assessing agricultural irrigation water use: $114 \mathrm{p}$.

Wyant, T. S., and Shoemyen, J. L., 1980, Estimating irrigation water use through selective monitoring: a north Florida case study: Water Resources Bulletin, v. 16, no. 6, p. 1074-79. 



W

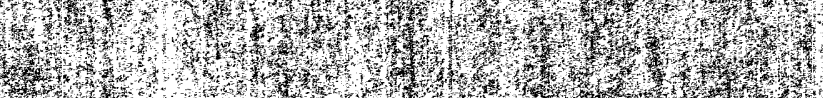

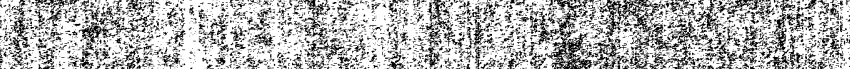

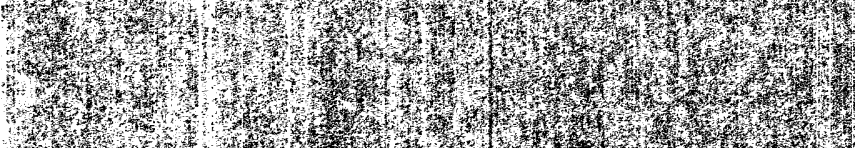

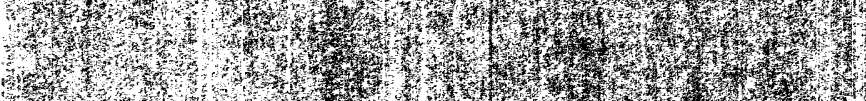

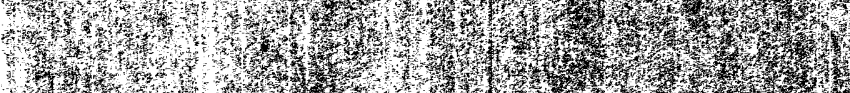
17. 467x r.

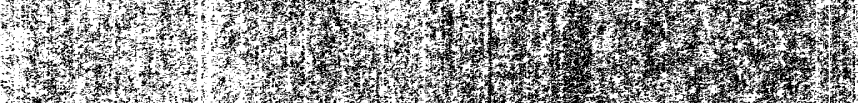
37.

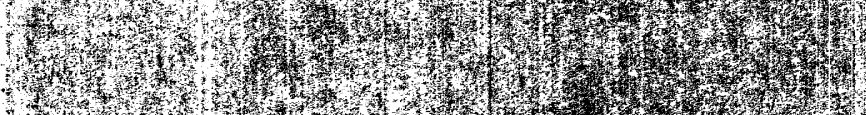
1.7.

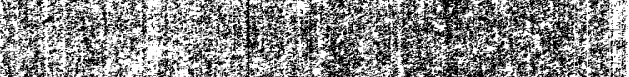
Wr 1.

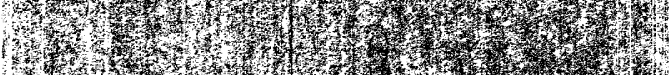
m.t. HWr

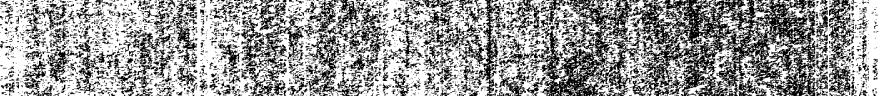

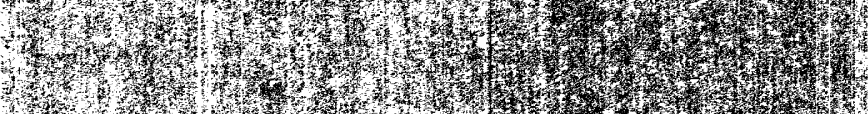

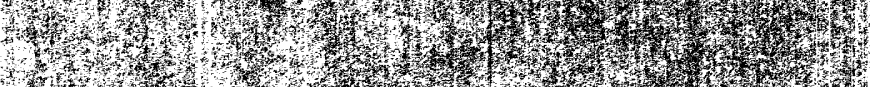

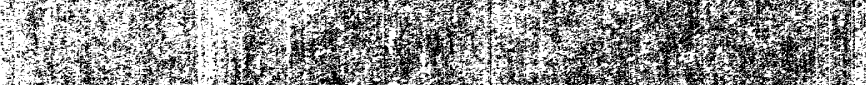

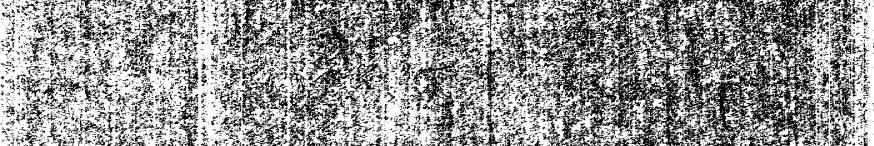

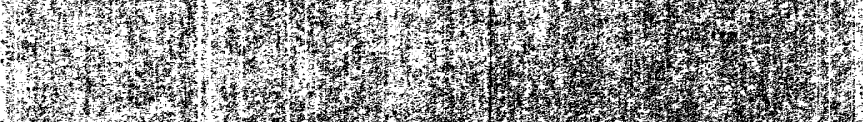
17
M

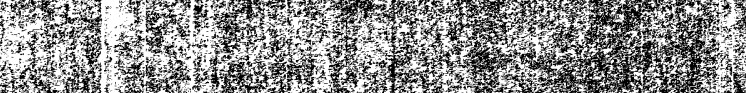

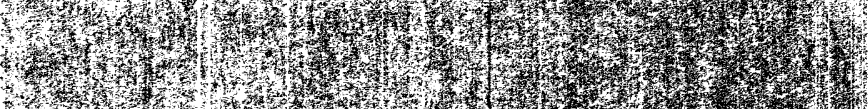

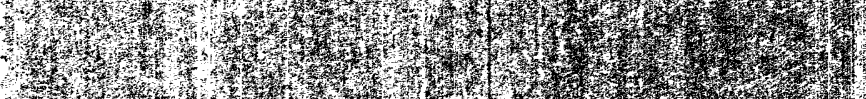
W 1. Hrow

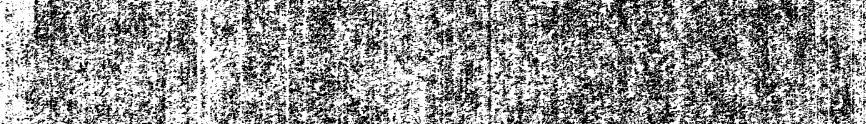

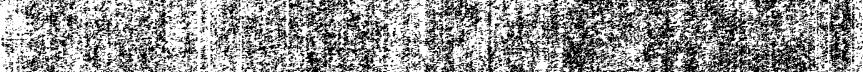

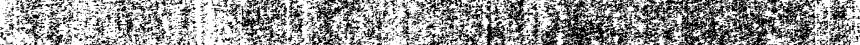

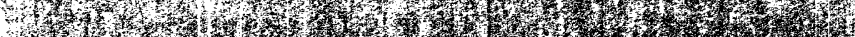
13

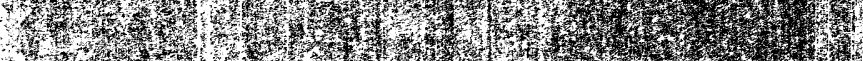
H.t.

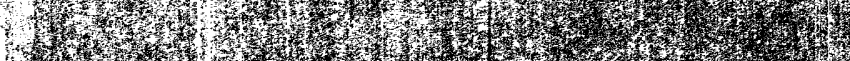

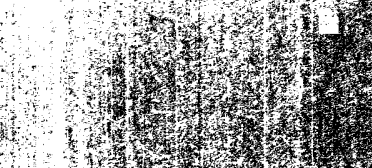

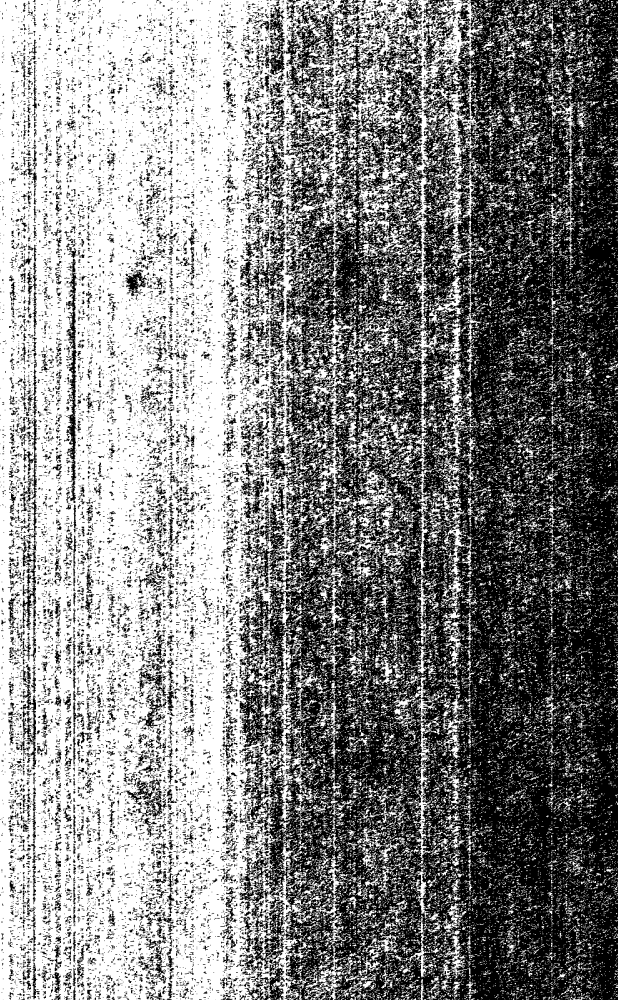
\%) 1:

1)

3. mothrom 茫 \%

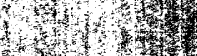

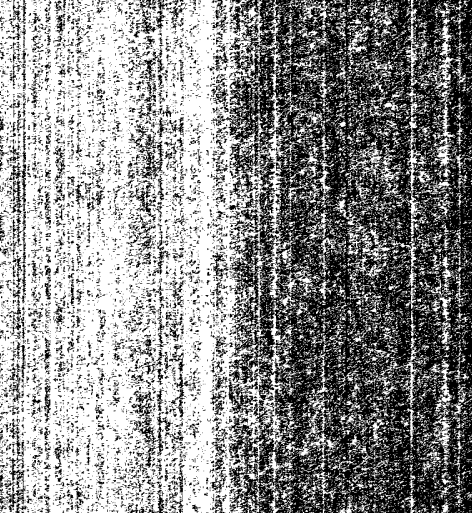

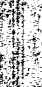

H)

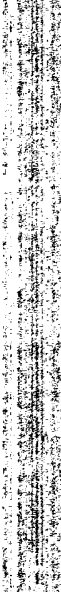

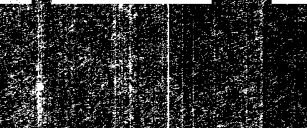


(1)

HWw 17w

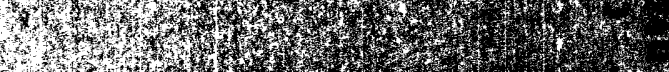

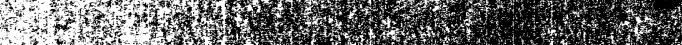

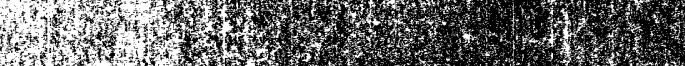

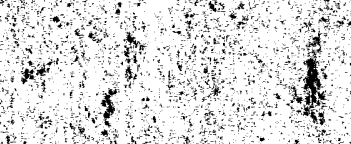
1.

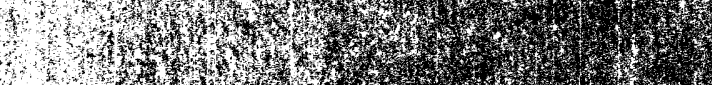
1, 3.

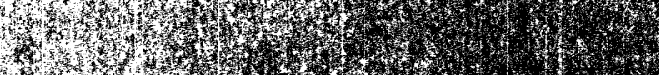

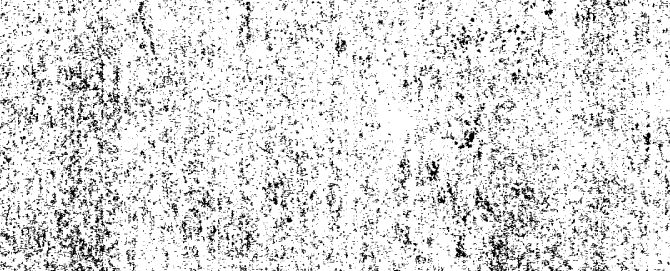

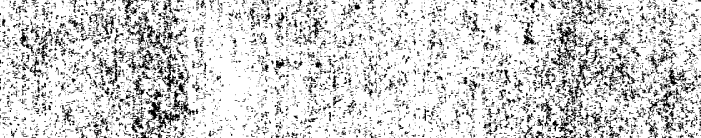
wantw motho Wh

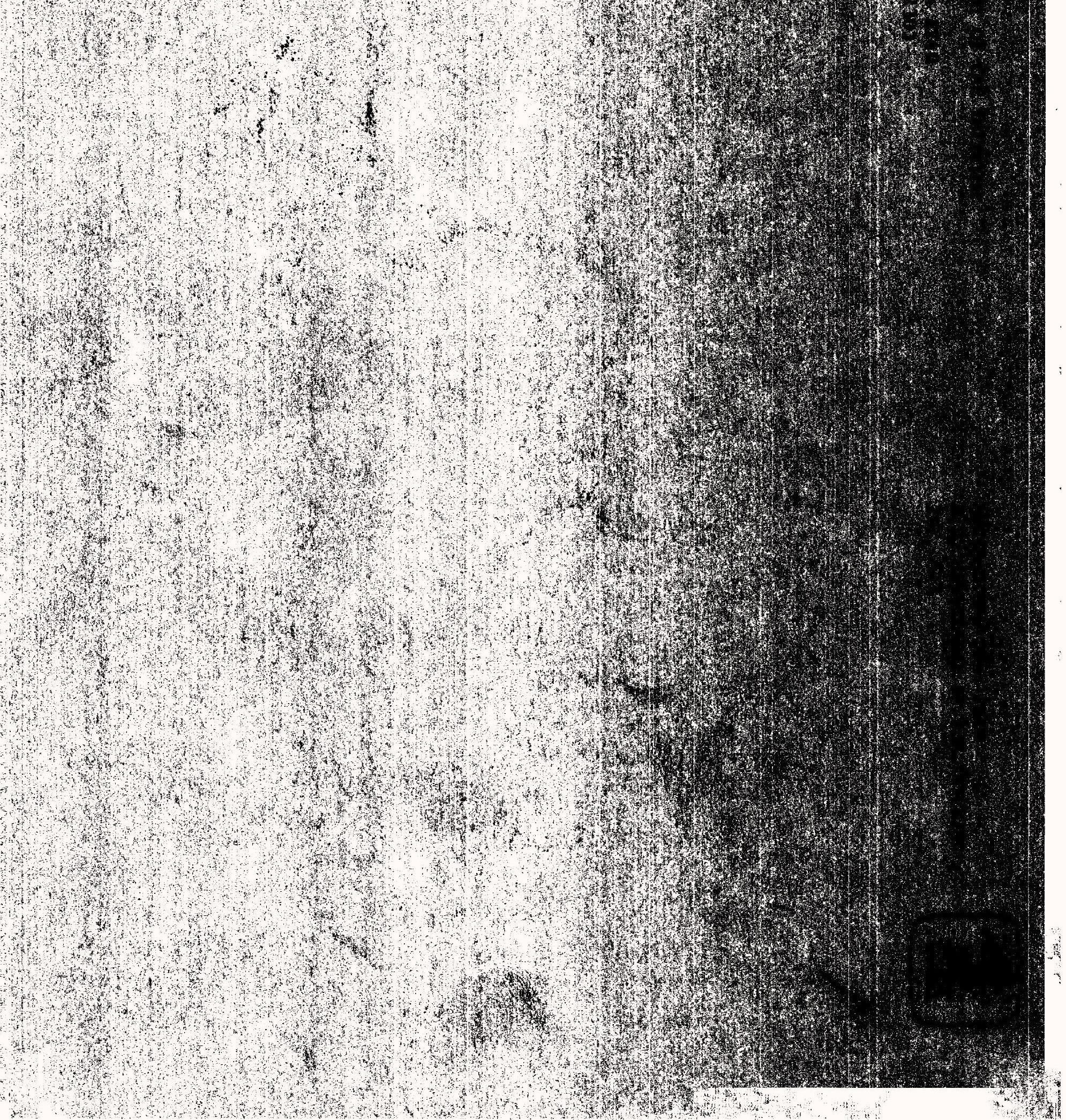

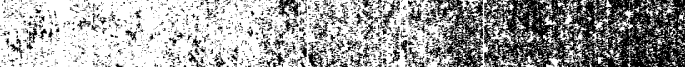
WW 3.t.

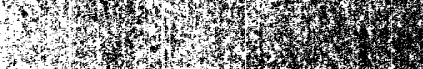

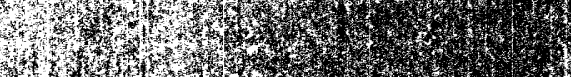

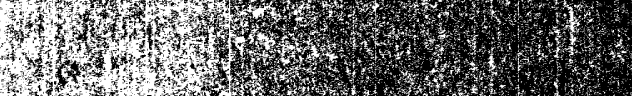

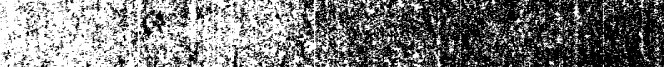

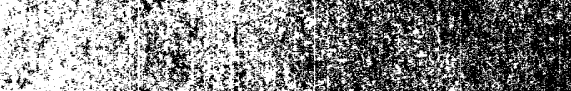
1.1,

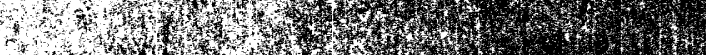

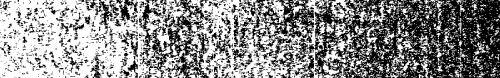
W,

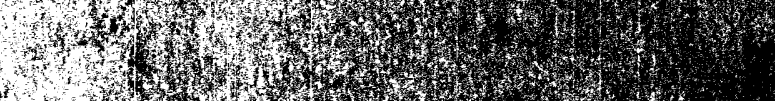
2. 3 .

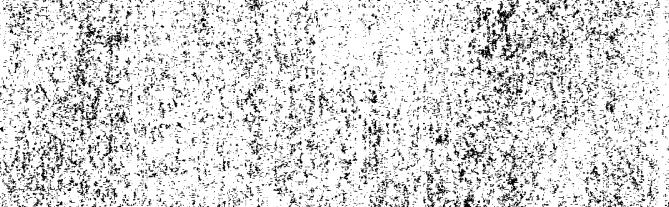

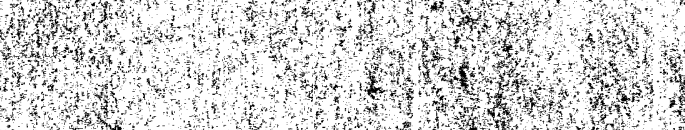
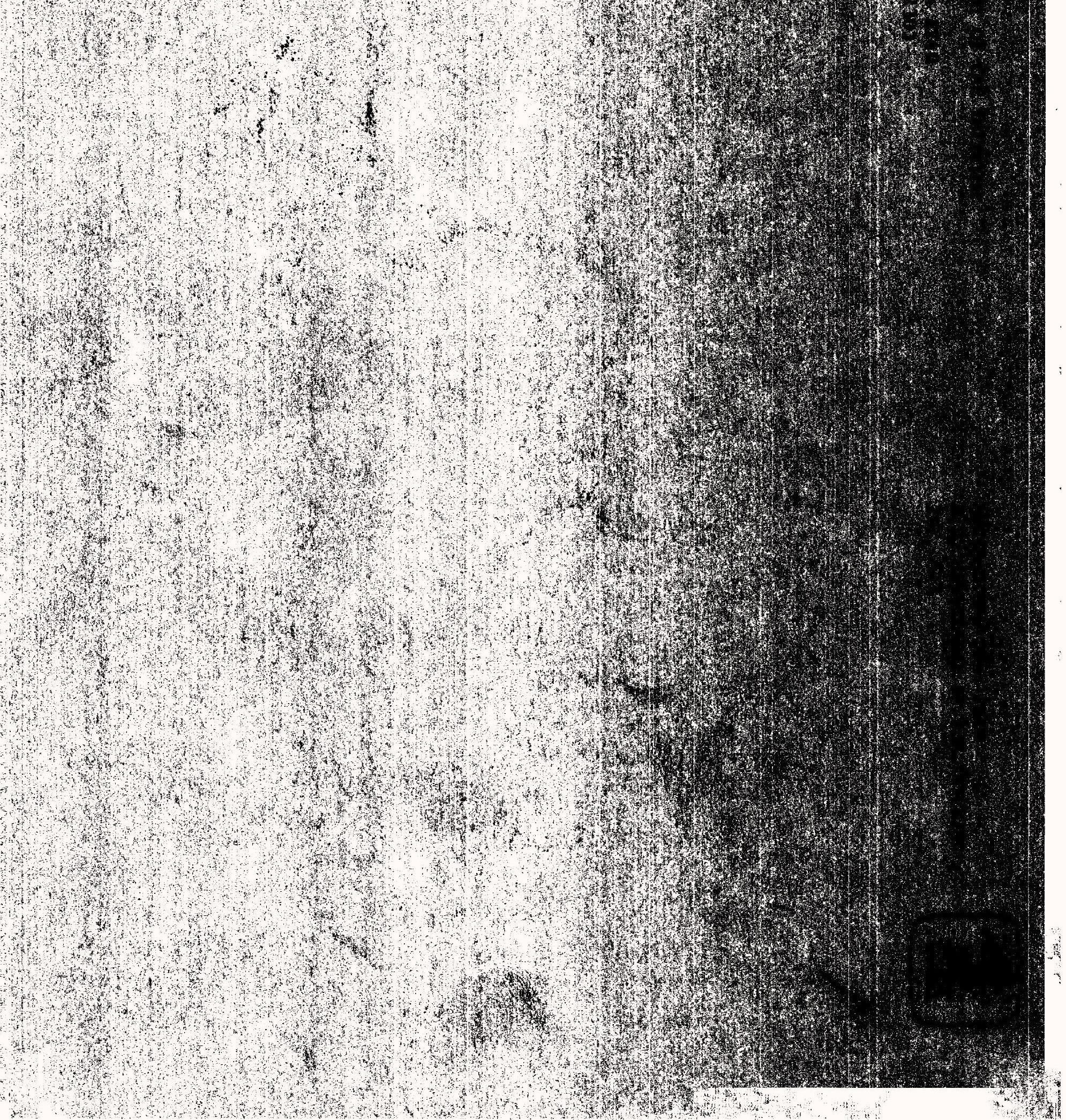

$$
\begin{aligned}
& \begin{array}{l}
4 \\
6
\end{array} \\
& \text { W }+135 \\
& \text { (r) }
\end{aligned}
$$$$
\text { +nes }
$$

$$
\text { W }
$$$$
\text { the }
$$$$
\begin{array}{ll} 
\\
4 \\
4 \\
3 \\
4
\end{array}
$$

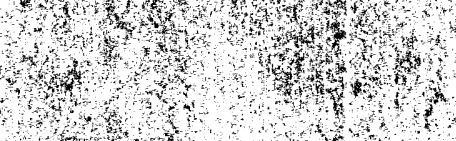

$$
\begin{aligned}
& \text { Why } \\
& \text { Wh }
\end{aligned}
$$$$
+3
$$

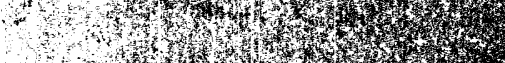
matr.

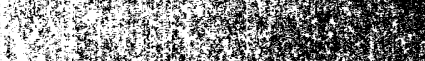

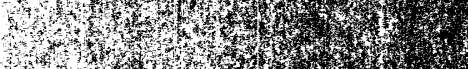
4 t. 4

\section{II} .

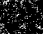
. X.t. \% \% rat $\sqrt{3}$ 3) $(4,4)$ 